Prepared in cooperation with the Puerto Rico Environmental Quality Board

\title{
Hydrologic and Water-Quality Characteristics of Caño Boquerón, Cabo Rojo, and Puerto Mosquito, Isla de Vieques, Puerto Rico, July 2015-July 2016
}

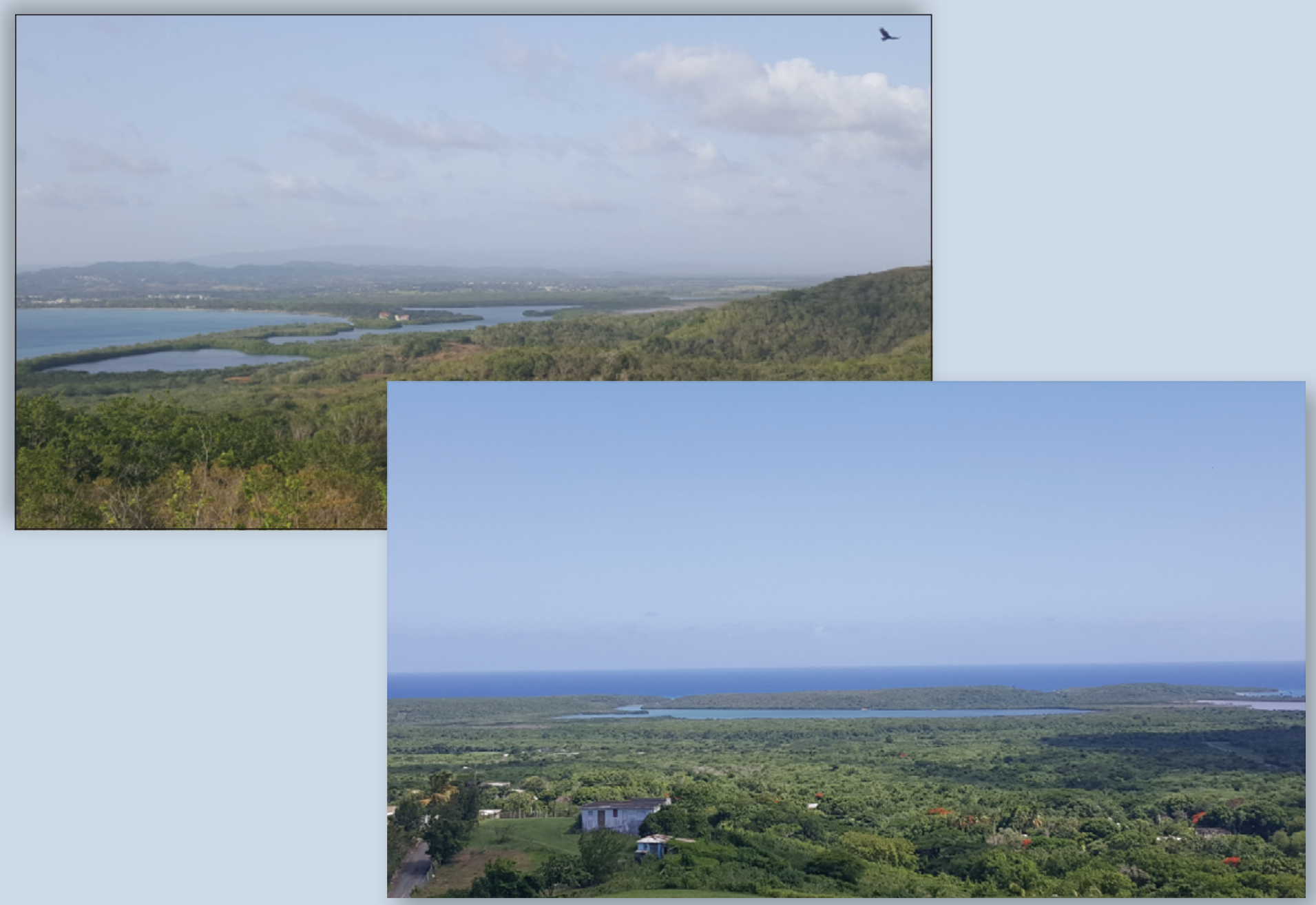

Scientific Investigations Report 2018-5018 
Cover. Top left: Caño Boquerón at Cabo Rojo. Bottom right: Puerto Mosquito on Isla de Vieques. Photos by Julieta M. Gómez-Fragoso. 


\section{Hydrologic and Water-Quality Characteristics of Caño Boquerón, Cabo Rojo, and Puerto Mosquito, Isla de Vieques, Puerto Rico, July 2015-July 2016}

By Julieta M. Gómez-Fragoso and José A. Santiago-Sáez

Prepared in cooperation with the Puerto Rico Environmental Quality Board

Scientific Investigations Report 2018-5018 


\title{
U.S. Department of the Interior \\ RYAN K. ZINKE, Secretary
}

\section{U.S. Geological Survey William H. Werkheiser, Deputy Director exercising the authority of the Director}

\author{
U.S. Geological Survey, Reston, Virginia: 2018
}

For more information on the USGS - the Federal source for science about the Earth, its natural and living resources, natural hazards, and the environment-visit https://www.usgs.gov or call 1-888-ASK-USGS.

For an overview of USGS information products, including maps, imagery, and publications, visit https://store.usgs.gov.

Any use of trade, firm, or product names is for descriptive purposes only and does not imply endorsement by the U.S. Government.

Although this information product, for the most part, is in the public domain, it also may contain copyrighted materials as noted in the text. Permission to reproduce copyrighted items must be secured from the copyright owner.

Suggested citation:

Gómez-Fragoso, J.M., and Santiago-Sáez, J.A., 2018, Hydrologic and water-quality characteristics of Caño Boquerón, Cabo Rojo, and Puerto Mosquito, Isla de Vieques, Puerto Rico, July 2015-July 2016: U.S. Geological Survey Scientific Investigations Report 2018-5018, 34 p., https://doi.org/10.3133/sir20185018.

ISSN 2328-0328 (online) 


\section{Acknowledgments}

The authors thank the Puerto Rico Environmental Quality Board for cooperation and support during the study. The U.S. Fish and Wildlife Service on Isla de Vieques, Vieques Conservation and Historical Trust, and the Puerto Rico Department of Natural Resources also provided support during planning and with the logistics involved in field data collection. In addition, the authors thank Adail Rivera (University of Puerto Rico-Mayagüez Campus) and Javier E. Bidot \& Associates for the support associated with establishing the elevation controls at the study areas.

The authors also thank the colleagues of the U.S. Geological Survey Caribbean-Florida Water Science Center for the help and support during field data collection. Special recognition is given to Josybeth Santiago, Angel Torres, and Yaniré Martínez, who contributed to water sampling. The authors also thank Luis Soler (U.S. Geological Survey retiree and volunteer), who contributed to field data collection and data processing, and Marilyn Santiago who provided assistance with the preparation of geospatial data. 



\section{Contents}

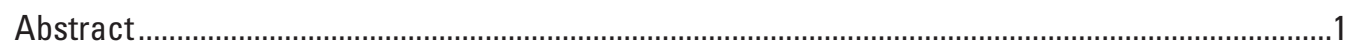

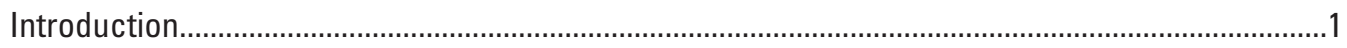

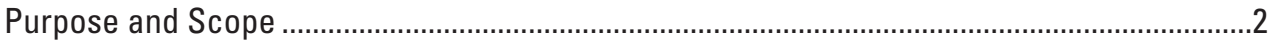

Description of Study Area .........................................................................................................2

Methods of Investigation........................................................................................................................

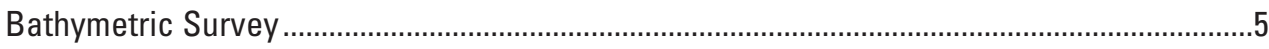

Rainfall Data Collection and Surface Water ..........................................................................

Water-Quality Sampling and Analysis..................................................................................6

Determination of Biological Characteristics..............................................................................

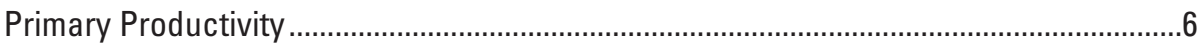

Net Phytoplankton Primary Productivity......................................................................7

Net Community Primary Productivity ..........................................................................

Other Biological Health Indicators ..................................................................................

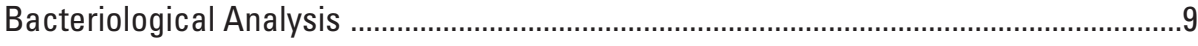

Seawater Exchange ……………………………………………………………………………9

Sediment Core Collection and Analysis.................................................................................9

Results and Discussion ..........................................................................................................10

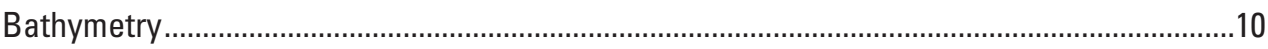

Rainfall Data Collection and Surface Water .........................................................................10

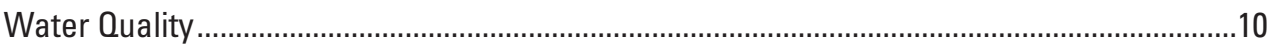

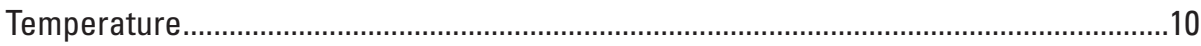

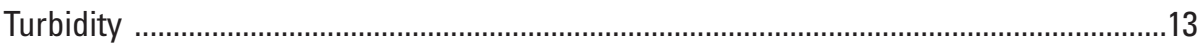

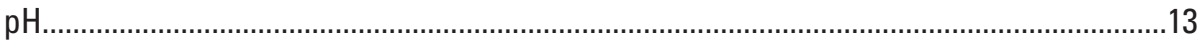

Dissolved Oxygen Concentration ……………………………………………………....14

Specific Conductance .......................................................................................................14

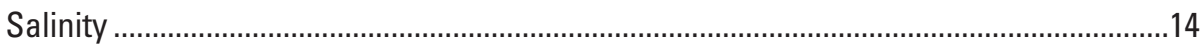

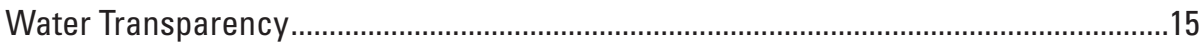

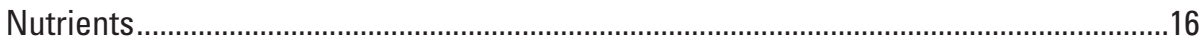

Cross-Sectional Profiles of Physicochemical Properties at Puerto Mosquito on Isla de Vieques ..............................................................................................17

Biological Characteristics .......................................................................................................17

Primary Productivity ....................................................................................................17

Net Phytoplankton Primary Productivity, Plankton Respiration, and Gross

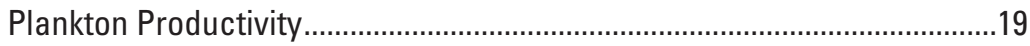

Net Community Primary Productivity, Respiration, and Gross Productivity ...........22

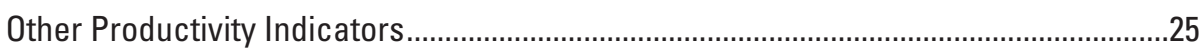

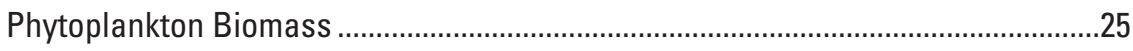

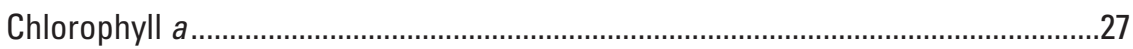

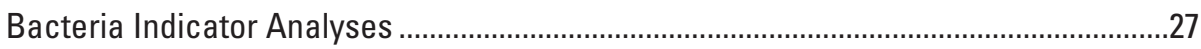

Seawater Exchange …………………………………………………………………………...28

Sediment Accretion .........................................................................................................28

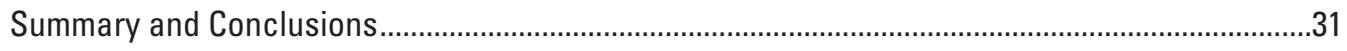

References Cited............................................................................................................... 


\section{Figures}

1. Composite showing Puerto Rico and locations of Caño Boquerón at Cabo Rojo, and Puerto Mosquito on Isla de Vieques.

2. Aerial photograph showing location of Caño Boquerón at Cabo Rojo, Puerto Rico, and sampling sites used in the study....

3. Aerial photograph showing location of Puerto Mosquito on Isla de Vieques, Puerto Rico, and sampling sites used in the study....

4. Map showing bathymetry of Caño Boquerón, Cabo Rojo, Puerto Rico, August 2015.

5. Map showing bathymetry of Puerto Mosquito, Isla de Vieques, Puerto Rico, August 2015.

6. Graph showing daily rainfall collected at CB No. 3, Caño Boquerón, Cabo Rojo, Puerto Rico, July 1, 2015 to July 28, 2016.

7. Graph showing daily rainfall collected at PM No. 1, Puerto Mosquito, Isla de Vieques, Puerto Rico, July 1, 2015 to July 28, 2016.

8. Boxplot graph showing specific conductance measurements at Caño Boquerón, Cabo Rojo, and Puerto Mosquito, Isla de Vieques, Puerto Rico, from July 2015 to July 2016

9. Aerial photograph showing the location of points along a cross-sectional profile where water-quality measurements were collected at Puerto Mosquito, Isla de Vieques, Puerto Rico, June 16, 2016.

10. Cross-sectional profile showing dissolved oxygen concentrations at Puerto Mosquito, Isla de Vieques, Puerto Rico, June 16, 2016

11. Cross-sectional profile showing specific conductance concentrations at Puerto Mosquito, Isla de Vieques, Puerto Rico, June 16, 2016.

12. Diagram showing primary productivity configuration using estimates for Caño Boquerón, Cabo Rojo, Puerto Rico

13. Graph showing diurnal variation in dissolved oxygen concentrations during diel study at CB. No. 4, Caño Boquerón, Cabo Rojo, Puerto Rico, October 29, 2015

14. Graph showing diurnal variation in dissolved oxygen concentrations during diel study at PM No. 7, Puerto Mosquito, Isla de Vieques, Puerto Rico, March 9, 2016

15. Graph showing relation between biomass and net community primary productivity measured in diel studies at CB No. 1 and CB No. 2, Caño Boquerón, Cabo Rojo, Puerto Rico, November 2015 and March 2016.

16. Graph showing relation of cesium-137 and lead-210 with sediment core depth in CB No. 2, Caño Boquerón, Cabo Rojo, Puerto Rico, December 2015.

17. Graph showing relation of cesium-137 and lead-210 with sediment core depth in PM No. 7, Puerto Mosquito, Isla de Vieques, Puerto Rico, January 2016.

\section{Tables}

1. Description of analyses of samples collected from sampling stations located at Caño Boquerón, Cabo Rojo, and Puerto Mosquito, Isla de Vieques, Puerto Rico, July 2015-July 2016 .

2. Methods of sample collection and preservation used at Caño Boquerón and Puerto Mosquito, Puerto Rico, July 2015-July 2016 
3. Results of turbidity analysis at Caño Boquerón, Cabo Rojo, and Puerto Mosquito, Isla de Vieques, Puerto Rico.

4. Total nitrogen concentrations from unfiltered samples collected at selected sites at Caño Boquerón, Cabo Rojo, and Puerto Mosquito, Isla de Vieques, Puerto Rico .

5. Phosphorous concentrations from unfiltered samples collected at selected sites at Caño Boquerón, Cabo Rojo, and Puerto Mosquito, Isla de Vieques, Puerto Rico

6. Primary productivity by phytoplankton at CB No. 1 in Caño Boquerón, Cabo Rojo, Puerto Rico, July 2015-July 2016

7. Primary productivity by phytoplankton at CB No. 2 in Caño Boquerón, Cabo Rojo, Puerto Rico, July 2016-July 2017

8. Primary productivity by phytoplankton at PM No. 2 in Puerto Mosquito, Isla de Vieques, Puerto Rico, July 2015-July 2016.

9. Primary productivity by phytoplankton at PM No. 7 in Puerto Mosquito, Isla de Vieques, Puerto Rico, July 2015-July 2016.

10. Results of diel study of community primary productivity at Caño Boquerón, Cabo Rojo, Puerto Rico.

11. Results of diel study of community primary productivity at Puerto Mosquito, Isla de Vieques, Puerto Rico

12. Summary of primary productivity results at Caño Boquerón, Cabo Rojo, and Puerto Mosquito, Isla de Vieques, Puerto Rico, July 2015-July 2016.

13. Phytoplankton biomass concentrations from samples collected at selected sites at Caño Boquerón, Cabo Rojo, and Puerto Mosquito, Isla de Vieques, Puerto Rico

14. Chlorophyll a concentrations from samples collected at selected sites at Caño Boquerón, Cabo Rojo, and Puerto Mosquito, Isla de Vieques, Puerto Rico, July 2015-July 2016

15. Fecal coliform and enterococci concentrations from samples collected at selected sites at Caño Boquerón, Cabo Rojo, and Puerto Mosquito, Isla de Vieques, Puerto Rico, July 2015-July 2016 


\section{Conversion Factors}

\begin{tabular}{|c|c|c|}
\hline Multiply & By & To obtain \\
\hline \multicolumn{3}{|c|}{ Length } \\
\hline micrometer $(\mu \mathrm{m})$ & $3.937 \times 10^{-5}$ & inch (in.) \\
\hline millimeter $(\mathrm{mm})$ & 0.03937 & inch (in.) \\
\hline centimeter $(\mathrm{cm})$ & 0.3937 & inch (in.) \\
\hline meter (m) & 3.281 & foot $(\mathrm{ft})$ \\
\hline kilometer (km) & 0.6214 & mile (mi) \\
\hline \multicolumn{3}{|c|}{ Area } \\
\hline square kilometer $\left(\mathrm{km}^{2}\right)$ & 247.1 & acre \\
\hline hectare (ha) & 2.47105 & acre \\
\hline square kilometer $\left(\mathrm{km}^{2}\right)$ & 0.3861 & square mile $\left(\mathrm{mi}^{2}\right)$ \\
\hline \multicolumn{3}{|c|}{ Volume } \\
\hline cubic meter $\left(\mathrm{m}^{3}\right)$ & 0.0002642 & million gallons (Mgal) \\
\hline cubic meter $\left(\mathrm{m}^{3}\right)$ & 35.31 & cubic foot $\left(\mathrm{ft}^{3}\right)$ \\
\hline cubic meter $\left(\mathrm{m}^{3}\right)$ & 0.0008107 & acre-foot (acre-ft) \\
\hline liter (L) & 0.2642 & gallon (gal) \\
\hline \multicolumn{3}{|c|}{ Accretion rate } \\
\hline centimeter per year $(\mathrm{cm} / \mathrm{yr})$ & 0.3937 & inch per year (in/yr) \\
\hline \multicolumn{3}{|c|}{ Flow rate } \\
\hline cubic meter per day $\left(\mathrm{m}^{3} / \mathrm{d}\right)$ & 264.2 & gallon per day (gal/d) \\
\hline \multicolumn{3}{|c|}{ Mass } \\
\hline gram (g) & 0.03527 & ounce, avoirdupois (oz) \\
\hline metric ton $(\mathrm{t})$ & 1.102 & ton, short $[2,000 \mathrm{lb}]$ \\
\hline \multicolumn{3}{|c|}{ Production } \\
\hline metric ton per year & 1.102 & ton, short, per year (ton/yr) \\
\hline \multicolumn{3}{|c|}{ Annual runoff } \\
\hline million cubic meters per year $\left(\mathrm{Mm}^{3}\right)$ & 35.31 & million cubic feet per year $\left(\mathrm{Mft}^{2} / \mathrm{yr}\right)$ \\
\hline \multicolumn{3}{|c|}{ Radioactivity } \\
\hline millibecquerel (mBq) & 37 & picocurie $(\mathrm{pCi})$ \\
\hline
\end{tabular}

Temperature in degrees Celsius $\left({ }^{\circ} \mathrm{C}\right)$ may be converted to degrees Fahrenheit $\left({ }^{\circ} \mathrm{F}\right)$ as ${ }^{\circ} \mathrm{F}=\left(1.8 \times{ }^{\circ} \mathrm{C}\right)+32$.

Concentrations of chemical constituents in water are given in either milligrams per liter (mg/L) or micrograms per liter ( $\mu \mathrm{g} / \mathrm{L})$. 


\section{Datum}

Vertical coordinate information for USGS gaging stations 50129935 and 50231500 is referenced to local mean sea level as defined by the Puerto Rico Vertical Datum of 2002 (PRVD02). The Puerto Rico Vertical Datum of 2002 consists of a leveling network on the island of Puerto Rico affixed to a single origin point and was affirmed as the official vertical datum in the National Spatial Reference System for Puerto Rico.

Horizontal coordinate information is referenced to the North American Datum of 1983 (NAD 83).

Elevation, as used in this report, refers to distance above or below the vertical datum.

\section{Abbreviations}

DO dissolved oxygen

NOAA National Oceanic and Atmospheric Administration

NWIS National Water Information System

NWQL National Water Quality Laboratory

NTU nephelometric turbidity units

ppt parts per thousand

PREQB Puerto Rico Environmental Quality Board

USGS U.S. Geological Survey 



\title{
Hydrologic and Water-Quality Characteristics of Caño Boquerón, Cabo Rojo, and Puerto Mosquito, Isla de Vieques, Puerto Rico, July 2015-July 2016
}

\author{
By Julieta M. Gómez-Fragoso and José A. Santiago-Sáez
}

\section{Abstract}

Coastal lagoons are common features of the Puerto Rico shoreline that provide habitat for commercial and recreational species and serve important roles in the nutrient cycle of the ecosystems. The U.S. Geological Survey, in cooperation with the Puerto Rico Environmental Quality Board, conducted a limnological study at Caño Boquerón in Cabo Rojo and at Puerto Mosquito on Isla de Vieques, Puerto Rico, to assess the principal mechanisms affecting the hydrology and water-quality characteristics of these coastal lagoons and provide baseline information to the regulatory agencies responsible for the management and conservation of these coastal waters and the preservation of their aquatic life.

Field measurements and water samples were collected and processed during July 2015-July 2016 for analysis of physical, chemical, biological, and bacteriological characteristics. In addition, bathymetric surveys were made and sediment cores were collected in each lagoon to determine water volume and sediment deposition rate. Physicochemical properties assessed at Caño Boquerón indicated values were generally in compliance with Puerto Rico Environmental Quality Board standards; turbidity was occasionally slightly greater than the established standards, and dissolved oxygen concentration at bottom depths was lower than standards limits. Water transparency was evaluated through the Secchi disk method, and the average depth of disappearance was 1.0 meter $(\mathrm{m})$ for Caño Boquerón and $1.9 \mathrm{~m}$ for Puerto Mosquito.

Assessment of biological characteristics at both sites included primary productivity calculations as well as carbon production equivalents and monthly water sampling for bacteriological and nutrient analyses. For Caño Boquerón, gross plankton primary productivity averaged 3.38 grams of oxygen per cubic meter per day $\left(\mathrm{gO}_{2} / \mathrm{m}^{3}-\mathrm{d}\right)$; this value was computed as the sum of net phytoplankton primary productivity $\left(0.74 \mathrm{gO}_{2} / \mathrm{m}^{3}-\mathrm{d}\right)$ and plankton respiration $\left(2.64 \mathrm{gO}_{2} / \mathrm{m}^{3}-\mathrm{d}\right)$. Net community primary productivity averaged $1.44 \mathrm{gO}_{2} / \mathrm{m}^{3}-\mathrm{d}$, and the community respiration rate averaged $8.10 \mathrm{gO}_{2} / \mathrm{m}^{3}-\mathrm{d}$, which indicates that the biological community, aside from phytoplankton, acts as a net consumer rather than a net producer of biomass. In Puerto Mosquito, gross plankton primary productivity averaged $2.07 \mathrm{gO}_{2} / \mathrm{m}^{3}-\mathrm{d}$, of which $0.39 \mathrm{gO} / \mathrm{m}^{3}-\mathrm{d}$ could be ascribed to net phytoplankton primary productivity, and $1.68 \mathrm{gO}_{2} / \mathrm{m}^{3}$ - $\mathrm{d}$ could be ascribed to plankton respiration. Diel studies conducted at Puerto Mosquito reflected an average net community primary productivity of $2.43 \mathrm{gO}_{2} / \mathrm{m}^{3}-\mathrm{d}$, and the average respiration rate was $6.72 \mathrm{gO}_{2} / \mathrm{m}^{3}-\mathrm{d}$.

In a bathymetric survey conducted in August 2015, the water volume for the Caño Boquerón lagoon was calculated as 967,000 cubic meters $\left(\mathrm{m}^{3}\right)$, and the water volume at Puerto Mosquito was calculated as $1,182,200 \mathrm{~m}^{3}$, with an average depth of $1.5 \mathrm{~m}$ for Caño Boquerón and $1.8 \mathrm{~m}$ for Puerto Mosquito. The daily seawater exchange for Caño Boquerón and Puerto Mosquito was 13 and 5 percent of their water volumes referenced to mean sea level, respectively. A total of 20 sediment samples were processed and analyzed for cesium-137 $\left({ }^{137} \mathrm{Cs}\right)$ and lead-210 $\left({ }^{210} \mathrm{~Pb}\right)$ radioisotopes. Analyses indicated that the sediment deposition rate at Caño Boquerón ranged from 0.32 to 0.36 centimeter per year, based on age dating analysis of ${ }^{137} \mathrm{Cs}$ and ${ }^{210} \mathrm{~Pb}$ data; in Puerto Mosquito, the sediment deposition rate ranged from 0.26 to 0.27 centimeter per year, based on ${ }^{137} \mathrm{Cs}$ and ${ }^{210} \mathrm{~Pb}$ data.

Bacteriological analyses at Caño Boquerón and Puerto Mosquito indicated that fecal coliform and enterococci concentrations were below Puerto Rico Environmental Quality Board standards during the study. The highest concentrations of fecal coliform ( 22 colonies per 100 milliliters) and enterococci ( 9 colonies per 100 milliliters) at Caño Boquerón occurred in July, which coincided with the busiest season of vacation rentals near the lagoon. Bacteria concentrations were generally lower in Puerto Mosquito than in Caño Boquerón; maximum concentrations of fecal coliform and enterococci bacteria were measured in November 2015. The potential sources of contamination for Puerto Mosquito are limited, because it is within a conservation area.

\section{Introduction}

Puerto Rico has more than 30 coastal lagoons that provide a unique natural tropical habitat within the United States. These lagoons connect the terrestrial zone to nearby coastal zones (Mumby and Hastings, 2008). The shallow depth 
of coastal lagoons allows sunlight to penetrate the entire water column, thereby enhancing photosynthesis. During periods of high rainfall, the lagoons retain runoff and sediments and thus prevent pollution of coastal waters and reefs (Eisma, 1995). Because of their proximity to the ocean, the ecosystems within coastal lagoons are subjected to stressors such as variable salinity, which can affect the composition of aquatic communities (Chrysoula and others, 2014). Coastal lagoons serve as nurseries for many fish, mollusks, and other commercial species and provide refuge for resident and nonresident species of birds and other vertebrates. Lagoons are valuable, natural laboratories where scientists and the general public can acquire and expand their knowledge about ecology, and they also provide a popular setting for recreation.

Coastal lagoons can sequester atmospheric carbon dioxide through production of organic carbon. Two limnological studies conducted in southern Puerto Rico and eastern Puerto Rico indicated a minimum net organic carbon production of 400 metric tons per year (Laguna de Las Salinas, 35 hectares [ha]) and 507 metric tons per year (Laguna Grande, 50 ha) (Soler-López and others, 2005; Soler-López and Santos, 2010). This net organic matter production represents an estimated carbon dioxide removal from the atmosphere of more than 1,200 metric tons per year per lagoon (Soler-López and others, 2005; Soler-López and Santos, 2010). Similar results were obtained by the U.S. Geological Survey (USGS) at Laguna Tortuguero (Quiñones-Márques and Fusté, 1977).

To improve the understanding of coastal lagoons in Puerto Rico, the USGS Caribbean-Florida Water Science Center, in cooperation with the Puerto Rico Environmental Quality Board (PREQB), conducted a study during 2014 to identify baseline water-quality conditions at 20 coastal lagoons in the main island, and one on the island of Vieques (Puerto Rico Environmental Quality Board, 2014a). Water-sampling results are available in the USGS National Water Information System (NWIS) database (U.S. Geological Survey, 2017). The study indicated that most water-quality characteristics were within the range of water-quality standards established by the PREQB; however, some measurements of turbidity and dissolved oxygen (DO) concentration were out of established ranges. Based on those results, the PREQB asked the USGS to conduct a hydrologic and water-quality analysis for Puerto Mosquito on Isla de Vieques, and Caño Boquerón at Cabo Rojo, Puerto Rico (fig. 1). This report summarizes the water-quality and hydrologic conditions monitored at both sites from July 2015 to July 2016.

\section{Purpose and Scope}

The purpose of this report is to summarize the results of a limnological study at Caño Boquerón and Puerto Mosquito, Puerto Rico (fig. 1). The main objectives of the study were to (1) assess the principal mechanisms affecting the hydrology and water-quality characteristics of the coastal lagoons and (2) provide baseline information to the regulatory agencies responsible for the management and conservation of coastal waters.

The study includes two lagoons that represent coastal waters under disturbed (Caño Boquerón) and undisturbed (Puerto Mosquito) conditions. Physical, chemical, and biological parameters were assessed, and results were compiled and analyzed from the monthly sampling events in each lagoon to determine possible stressors affecting the health of the aquatic ecosystems. Additional data collection was used to determine community and plankton primary productivity, sediment deposition rates, and seawater exchange rates. A comparative analysis of findings in both lagoons was made to determine the compliance of lagoons with regulatory standards as well as to evaluate the effects of possible disturbances in the aquatic habitats.

\section{Description of Study Area}

The study area includes Caño Boquerón and Puerto Mosquito, coastal waters under the jurisdiction of the Puerto Rico Department of Natural and Environmental Resources. Caño Boquerón is in southwestern Puerto Rico in the municipality of Cabo Rojo and 9.2 kilometers $(\mathrm{km})$ south of the town of Cabo Rojo. Puerto Mosquito is located on Isla de Vieques, an island about $78 \mathrm{~km}$ southeast of San Juan (fig. 1).

Caño Boquerón (fig. 2), also referred as Laguna Rincón, is part of the Boquerón Natural Reserve, which also includes the Boquerón State Forest and the Boquerón Wildlife Refuge. Caño Boquerón has a surface area of 63 ha including the lagoon and inlet/outlet channel connecting it to the ocean. In Caño Boquerón, there are no streams that discharge directly to the lagoon. The only freshwater input from surface sources occur during heavy rainfall from overland flow, and runoff received from overflow of the Canal Principal de Riego Valle de Lajas (an irrigation canal). Freshwater input from groundwater is minimal. The Caño Boquerón drainage area encompasses about 71.19 square kilometers $\left(\mathrm{km}^{2}\right)$, and the mean annual precipitation (1981-2010) is 1,219 millimeters (mm) (National Oceanic and Atmospheric Administration, 2010). Caño Boquerón is completely surrounded by a dense growth of mangroves and tidal swamps, with a small area of tidal flats at the east and south edges of the lagoon. The soil layer underlying the mangroves and the bottom of the lagoon is mostly composed of silt (Holocene) and fine sand (Volckmann, 1984).

Vieques is an island and one of the 78 municipalities of Puerto Rico. Puerto Mosquito (fig. 3) is a major tourist attraction found on Isla de Vieques, mainly because of the presence of bioluminescent dinoflagellates within its waters. With a surface area of 64 ha and a drainage area of $48.79 \mathrm{~km}^{2}$, Puerto Mosquito is one of the largest lagoons on Isla de Vieques. There are no active rain gages operated by the National Oceanic and Atmospheric Administration (NOAA) on Isla de Vieques; the nearest rain gage station is located in Ceiba (Roosevelt Roads weather station), and the mean annual precipitation (1981-2010) at that location is $1,329 \mathrm{~mm}$. 


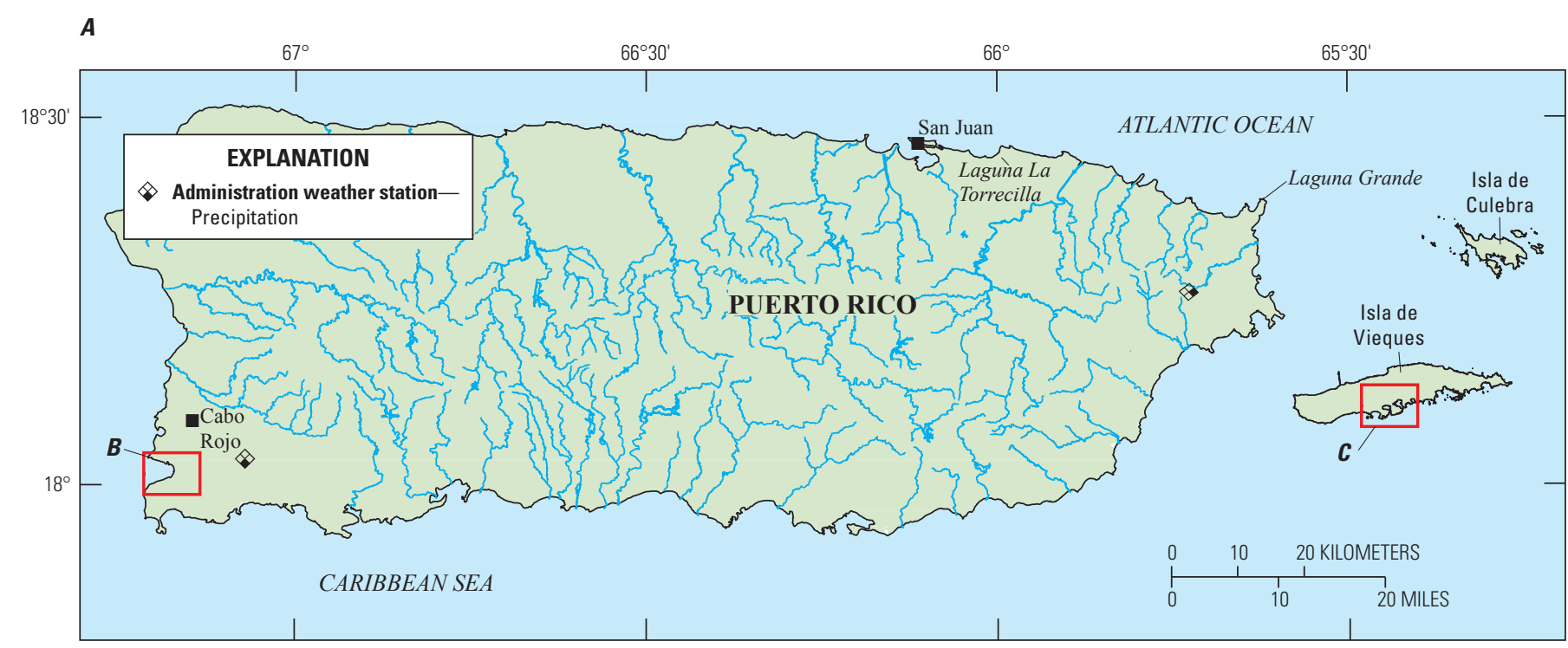

Base from US Geological Survey digital data North American Datum of 1983
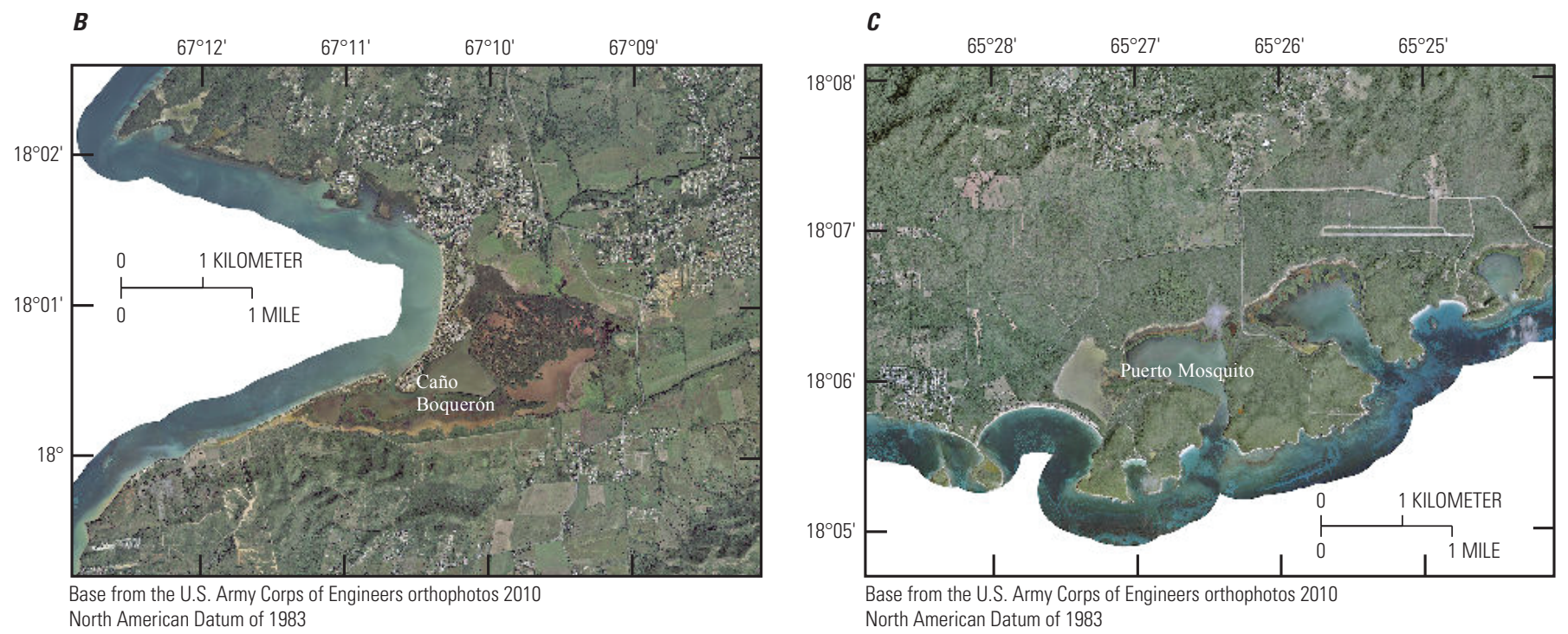

Figure 1. A, Puerto Rico and locations of $B$, Caño Boquerón at Cabo Rojo, and $C$, Puerto Mosquito on Isla de Vieques.

Puerto Mosquito is completely surrounded by a mangrove fringe barrier, which is in turn surrounded by widespread tidal flats. Isla de Vieques surface-water resources are limited because of its geographic and topographic location, and no streams are directly connected to the lagoon. The primary freshwater inputs to the lagoon are rainfall and runoff. The geologic setting that surrounds Puerto Mosquito is mostly marine sedimentary rocks of Miocene age and alluvial deposits composed of sand, silt, clay, and gravel (Briggs and Akers, 1965). High densities of bioluminescent dinoflagellates are a prominent component of the aquatic community in Puerto Mosquito, which has been designated as a body of water with high ecological and recreational importance (Puerto Rico Environmental Quality Board, 2014b). In 2014, bioluminescence levels of $3.72 \times 10^{12}$ photons per second per liter were reported (Soler-Figueroa, 2014).

\section{Methods of Investigation}

This study characterized hydrologic, physical, and chemical properties, sediment deposition rates, bathymetry, and biological conditions. Data were collected at Puerto Mosquito and Caño Boquerón during July 2015-July 2016. Field measurements were made and water samples for analysis of physical, chemical, biological, and bacteriological characteristics were collected and processed following USGS standards (U.S. Geological Survey, 2015). A total of five sites (or stations) per lagoon were sampled at both Caño Boquerón and Puerto Mosquito (figs. 2 and 3). Table 1 provides a description of the data collected at each station.

Physicochemical parameters were used to assess water quality at Caño Boquerón in Cabo Rojo and Puerto Mosquito on Isla de Vieques. Field properties included temperature, 


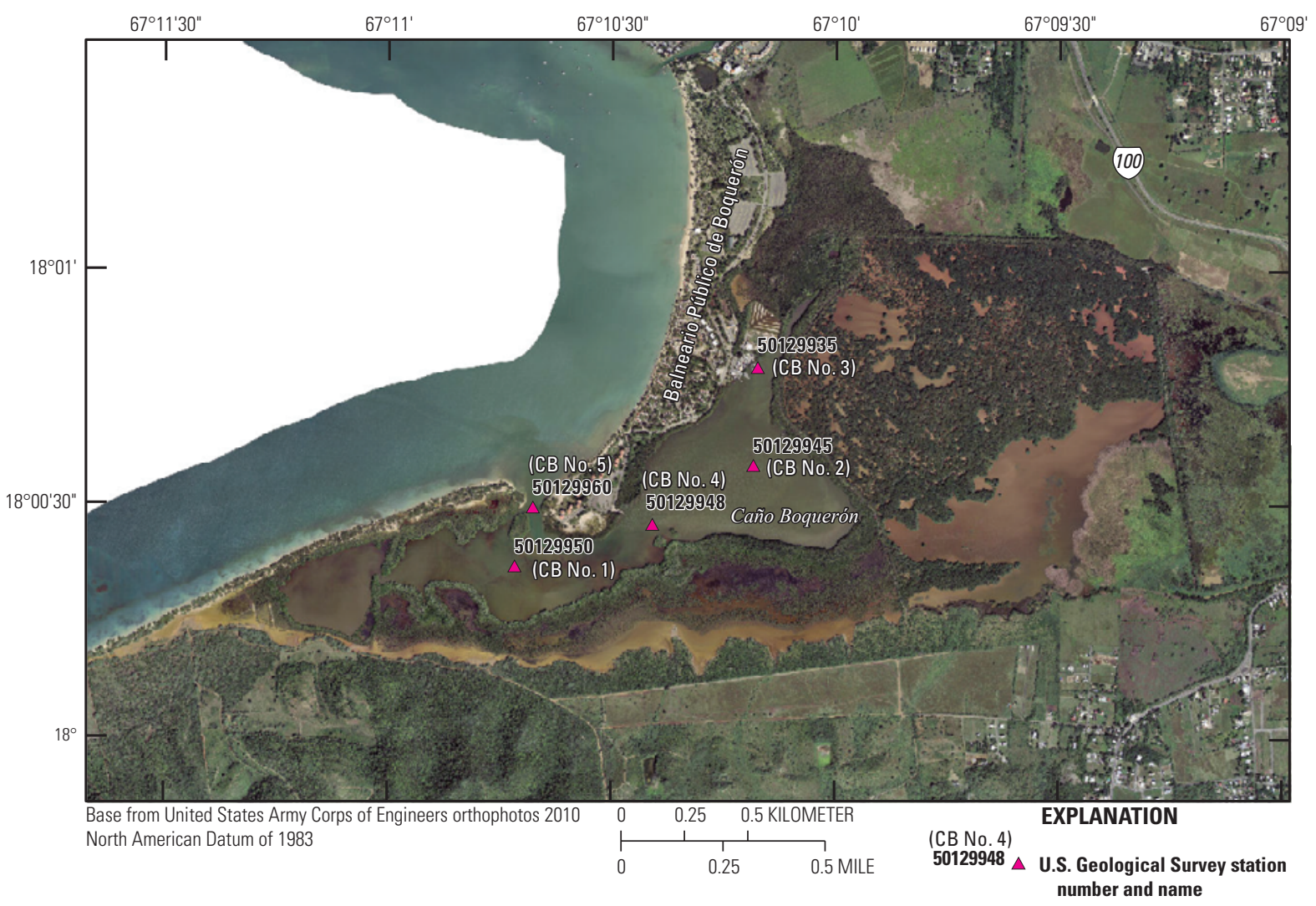

Figure 2. Caño Boquerón at Cabo Rojo, Puerto Rico, and sampling sites used in the study.

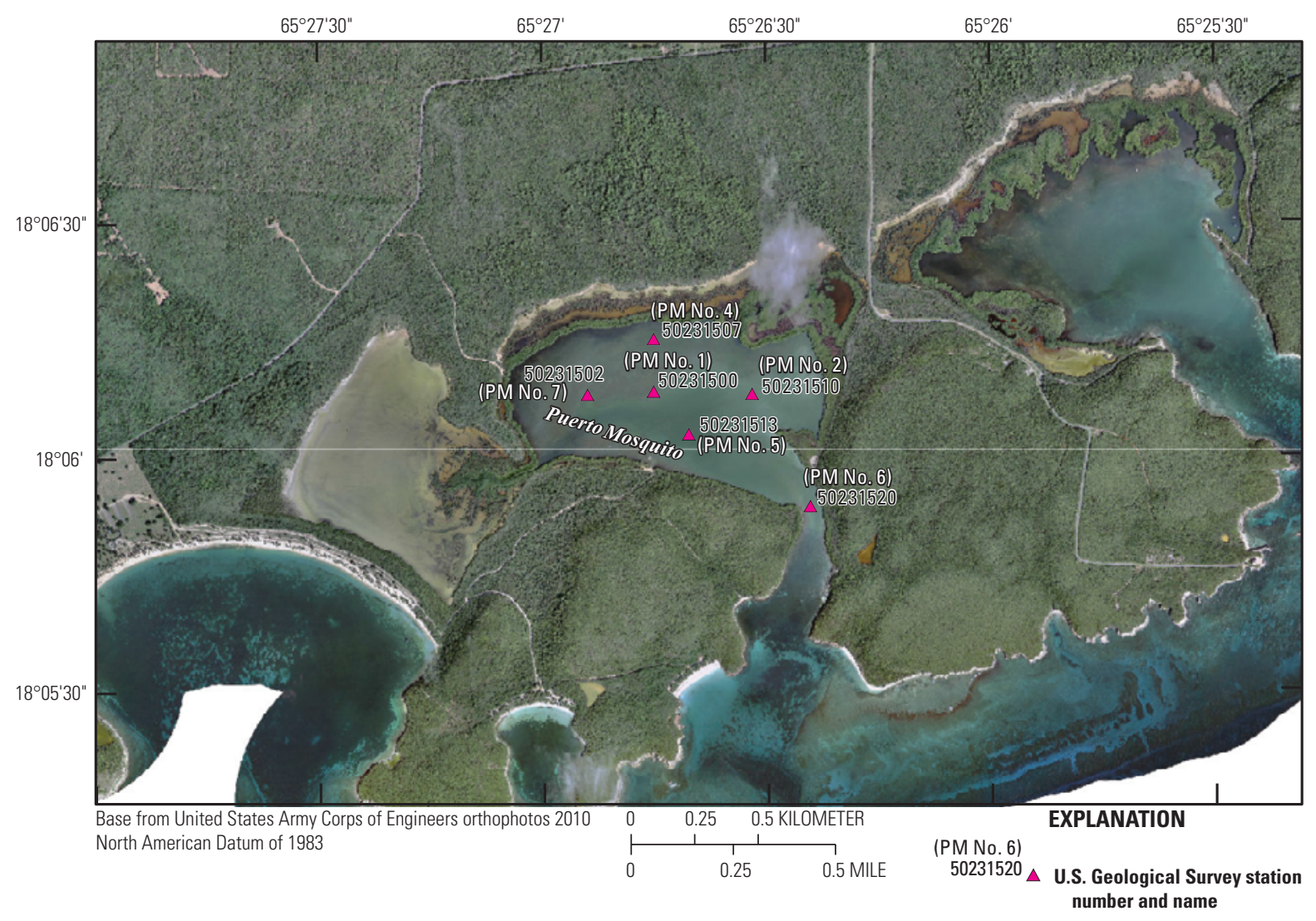

Figure 3. Puerto Mosquito on Isla de Vieques, Puerto Rico, and sampling sites used in the study. 
Table 1. Description of analyses of samples collected from sampling stations located at Caño Boquerón, Cabo Rojo, and Puerto Mosquito, Isla de Vieques, Puerto Rico, July 2015-July 2016.

[Monthly field-measured parameters included turbidity, $\mathrm{pH}$, dissolved oxygen concentration, specific conductance, salinity, and water transparency (Secchi disk depth); primary productivity was assessed using the light-dark method and diel study; USGS, U.S. Geological Survey; CB, Caño Boquerón; PM, Puerto Mosquito]

\begin{tabular}{|c|c|c|}
\hline $\begin{array}{l}\text { Station } \\
\text { name }\end{array}$ & $\begin{array}{c}\text { USGS station } \\
\text { identification } \\
\text { number }\end{array}$ & Determinations \\
\hline \multicolumn{3}{|r|}{ Caño Boquerón, Cabo Rojo } \\
\hline CB No. 1 & 50129950 & $\begin{array}{l}\text { Field-measured parameters, fecal and enterococcus bacteria indicator, turbidity, nutrients, primary pro- } \\
\text { ductivity, phytoplankton biomass, chlorophyll } a\end{array}$ \\
\hline CB No. 2 & 50129945 & $\begin{array}{l}\text { Field-measured parameters, fecal and enterococcus bacteria indicator, turbidity, nutrients, primary pro- } \\
\text { ductivity, phytoplankton biomass, chlorophyll } a \text {, sediment core sample (radioisotopes analyses) }\end{array}$ \\
\hline CB No. 3 & 50129935 & Field-measured parameters, primary productivity, precipitation \\
\hline CB No. 4 & 50129948 & Field-measured parameters, primary productivity \\
\hline CB No. 5 & 50129960 & Field-measured parameters, primary productivity \\
\hline \multicolumn{3}{|r|}{ Puerto Mosquito, Isla de Vieques } \\
\hline PM No. 1 & 50231500 & Real-time-water-quality and water-level monitoring, precipitation \\
\hline PM No. 5 & 50231513 & Field-measured parameters, primary productivity; sediment core sample (radioisotopes analyses) \\
\hline PM No. 6 & 50231520 & Field-measured parameters, primary productivity \\
\hline PM No. 7 & 50231502 & $\begin{array}{l}\text { Field-measured parameters, fecal and enterococcus bacteria indicator, turbidity, nutrients, primary pro- } \\
\text { ductivity, phytoplankton biomass, chlorophyll } a \text {, sediment core sample }\end{array}$ \\
\hline
\end{tabular}

turbidity, $\mathrm{pH}, \mathrm{DO}$, specific conductance, salinity, and water transparency. Water samples were analyzed for nutrients, fecal coliform and enterococci bacteria, chlorophyll $a$, and phytoplankton biomass. The water-quality classifications in Puerto Rico are based on the designated uses of a water body and the type of water resource (surface water, groundwater, and coastal waters). Three classifications exist for coastal and estuarine waters: Class SA, Class SB, and Class SC. Coastal waters under Class SA include bioluminescent lagoons and coastal waters with high ecological value. Class SB includes coastal waters neither included in Class SA nor Class SC. The Class SC includes segments of specific coastal and estuarine waters listed in the regulations of the PREQB (Puerto Rico Environmental Quality Board, 2014a). The two lagoons in the study were chosen by PREQB based on their classification: Puerto Mosquito is Class SA, whereas Caño Boquerón is Class SB (Puerto Rico Environmental Quality Board, 2014b). Although classification of coastal waters such as Puerto Mosquito is based on its ecological importance, no specific standards have been established regarding physicochemical and biological conditions, and thus an assessment of water-quality conditions is particularly useful at Puerto Mosquito because it is one of the coastal waters supporting bioluminescent dinoflagellates in Puerto Rico. For coastal waters in Class SB, water-quality standards have been established by the PREQB, and comparison of study results and PREQB standards is presented herein.

\section{Bathymetric Survey}

Depth-to-bottom contours and water volumes for Puerto Mosquito and Caño Boquerón inland waters were determined by conducting bathymetric surveys on August 11, 2015, and August 21, 2015, respectively. The bathymetric survey system used for the study consisted of coupling a Global Positioning System device with a water depth sounder. Established navigation lines were used to simultaneously collect water depth and geographic location data using a bathymetric system. Data were collected along 45 and 63 navigation lines during the bathymetric surveys for Caño Boquerón and Puerto Mosquito, respectively. Calibration of the water depth sounder (fathometer) was conducted prior to the beginning of data collection using the bar-check method (Thompson, 2014).

At each lagoon, a water-level station was deployed and was referenced to mean sea level datum by conducting a land survey. Post-processing of the data collected during the bathymetric survey included the adjustment of water depth data in order to provide values referenced to mean sea level. The adjustment process for the raw data or data points where water depth was collected during the bathymetric survey was made within the bathymetric system software prior to transferring the data into a geographic information system. The collection time of water depth (raw data) and water-level data at the gaging station (USGS gaging station referenced to mean sea level) were identified for the duration of the survey. 
A negative/positive sign was assigned to water levels at the gaging station (thereafter named as tide correction) based on whether gage height was above or below mean sea level. Finally, time/elevation correction was added to the raw data time series.

As noted above, the data (adjusted by applying time/elevation correction) were transferred into a geographic information system, and a bathymetric map was generated and referenced to mean sea level. The bathymetric map was used to create a triangulated irregular network model. The triangulated irregular network was used to generate the stage-volume curve of each lagoon referenced to mean sea level.

\section{Rainfall Data Collection and Surface Water}

Rainfall and runoff compose the inflow components of freshwater for the Caño Boquerón and Puerto Mosquito lagoons. Although both lagoons have intermittent inflows, substantial runoff can discharge into both lagoons during rainfall events. To account for freshwater entering into the lagoons, rain gages were installed at two USGS gaging stations (fig. 1 and 2): 50129935 (CB No. 3) and 50231500 (PM No. 1). Rainfall data were collected from July 1, 2015, to July 28, 2016; these data were quality assured for the purpose of this study and are presented in Gómez-Fragoso and Santiago-Sáez (2018).

Estimates of the inflow into both lagoons through runoff were made using the rainfall/runoff relation developed by Giusti and López (1967). This method allows for the determination of a rainfall/runoff ratio using a spatially developed climatic index map for Puerto Rico. The resulting estimates indicated that about 45 percent of streamflow can be attributed to rainfall, although Giusti and Lopez (1967) found variability throughout the island. Whereas the municipality of Isla de Vieques is not covered in the climatic index map for Puerto Rico, the aforementioned general rainfall/runoff ratio of 45 percent of rainfall was also used for Puerto Mosquito.

\section{Water-Quality Sampling and Analysis}

Field water-quality measurements of temperature, turbidity, $\mathrm{pH}, \mathrm{DO}$, salinity, and specific conductance were made monthly at five stations in each lagoon using a multiparameter water-quality instrument. Field parameters were measured at the surface (also referred to as "top" and measured at about 0.1 meter [m] depth) and at the bottom of the lagoon. Calibration and testing of the multiparameter instrument were conducted before each site visit and followed the techniques and standards established by the USGS (U.S. Geological Survey, 2015). A specific conductance sensor was calibrated using a one-point calibration and a potassium chloride conductivity standard of 50,000 microsiemens per centimeter at 25 degrees Celsius $\left(\mu \mathrm{S} / \mathrm{cm}\right.$ at $\left.25^{\circ} \mathrm{C}\right)$. The sensor for measuring $\mathrm{pH}$ was calibrated using the two-point calibration process and $\mathrm{pH}$ buffers for $\mathrm{pH} 7$ and $\mathrm{pH} 10$.
The criteria used for the selection of station locations included the proximity to the mouth of the lagoon, water depth, and potential nutrient inflow points. Results obtained from analysis of samples collected at Puerto Mosquito were compared with the standards established by PREQB for water bodies included in Class SA. Results for Caño Boquerón were evaluated using the established standards for Class SB because this lagoon has no specific PREQB classification (Puerto Rico Environmental Quality Board, 2014b). Values of monthly field-measured parameters are available through the NWIS database (U.S. Geological Survey, 2017). The Secchi disk and salinity data are presented in Gómez-Fragoso and Santiago-Sáez (2018),

Monthly samples for nutrients and chlorophyll $a$ analyses were collected from July 2015 to July 2016 at two sites in each lagoon and sent to the USGS National Water Quality Laboratory (NWQL) in Denver, Colorado, for analysis. A description of sample volumes, containers, and preservation methods used for each water sample is presented in table 2. Water transparency depths were measured using a Secchi disk. Sampling locations were selected on the basis of potential nutrient inflow and lagoon morphology. Analyses of nutrients included total phosphate and total nitrogen in unfiltered samples, and ammonia, organic nitrogen, nitrite, and nitrate in filtered samples. The results of the analyses are available through the USGS NWIS database (U.S. Geological Survey, 2017).

Continuous water-quality data were collected in Puerto Mosquito using a multiparameter sonde installed at station PM No. 1. Water-quality data measured by the continuous-monitoring sensors are not discussed in detail in this report; however, the data are available through NWIS (U.S. Geological Survey, 2017). The monitoring system was configured to collect the physicochemical parameters of temperature, turbidity, DO, and specific conductance. Site visits for sensor inspection and calibration were conducted every two months. Methods and techniques used for the operation and maintenance of the continuous water-quality monitoring system are described by Wagner and others (2006).

\section{Determination of Biological Characteristics}

Biological characteristics were determined using standard USGS field techniques and analysis methods (Britton and Greeson, 1987; U.S. Geological Survey, 2015). Samples were analyzed monthly from July 2015 to July 2016 to estimate primary productivity, phytoplankton biomass, and bacteriological communities; community primary productivity was assessed during the months with the highest and lowest tides (November 2015 and March 2016, respectively).

\section{Primary Productivity}

Primary productivity is defined as the rate at which organic matter is created by photosynthesis and is important for supporting the food web in aquatic ecosystems (Soler-López and Santos, 2010). Primary producers in 
Table 2. Methods of sample collection and preservation used at Caño Boquerón and Puerto Mosquito, Puerto Rico, July 2015-July 2016. [mL, milliliter; $\mu \mathrm{m}$, micrometer; ${ }^{\circ} \mathrm{C}$, degree Celsius; $\mathrm{L}$, liter; $\mathrm{mm}$, millimeter; $\mathrm{m}$, meter; $\mathrm{cm}$, centimeter]

\begin{tabular}{|c|c|c|c|c|}
\hline $\begin{array}{l}\text { Sample } \\
\text { matrix }\end{array}$ & Analyses & Sample volume & Sampler container & Method of sample preservation \\
\hline Water & $\begin{array}{l}\text { Nutrients (total dissolved } \\
\text { nitrogen, ammonia and } \\
\text { total phosphorus) }\end{array}$ & $125 \mathrm{~mL}$ & $\begin{array}{l}\text { Brown and white polyeth- } \\
\text { ylene bottles }\end{array}$ & $\begin{array}{l}\text { Brown bottle: } 0.45 \mu \mathrm{m} \text { filter } \\
\text { White bottle: field rinsed, preserved by adding } \\
\quad 1 \mathrm{~mL} \mathrm{H}_{2} \mathrm{SO}_{4} 4.5 \mathrm{~N} \text { and chilled at } 4{ }^{\circ} \mathrm{C}\end{array}$ \\
\hline Water & Chlorophyll $a$ & $1 \mathrm{~L}$ & $\begin{array}{l}\text { White polyethylene, field } \\
\text { rinsed }\end{array}$ & $\begin{array}{l}\text { Filtered through } 47-\mathrm{mm} \text { glass fiber filter, } \\
\text { wrapped in aluminum, dry ice }\end{array}$ \\
\hline Water & Phytoplankton biomass & $1 \mathrm{~L}$ & $\begin{array}{l}\text { White polyethylene, field } \\
\text { rinsed }\end{array}$ & $\begin{array}{l}\text { Filtered through } 47-\mathrm{mm} \text { glass fiber filter, } \\
\text { wrapped in aluminum, dry ice }\end{array}$ \\
\hline Water & Primary productivity & $300 \mathrm{~mL}$ & $\begin{array}{l}\text { Clear and dark glass } \\
\text { bottle (dissolved } \\
\text { oxygen concentration } \\
\text { measured) }\end{array}$ & $\begin{array}{l}\text { Bottles: initial (clear), clear and dark } \\
\text { Processed using the Winkler method. Reagents: } \\
\text { 1-pillow manganeous sulfate, 1-pillow alka- } \\
\text { line iodide, 1-pillow sulfamic acid. Chilled } \\
\text { at } 4{ }^{\circ} \mathrm{C}\end{array}$ \\
\hline Sediment & Cesium-137 and lead-210 & $\begin{array}{l}\text { Plastic liner of } 1-\mathrm{m} \\
\text { long by } 1.5-\mathrm{cm} \\
\text { diameter }\end{array}$ & $\begin{array}{l}\text { Clear polyethylene wide } \\
\text { mouth jar with caps }\end{array}$ & $\begin{array}{l}\text { Collected and capped at both ends. Stored } \\
\text { vertically. Let dry and cut the } 1-\mathrm{m} \text { long liner } \\
\text { into pieces of } 2 \mathrm{~cm} \text { in thickness. }\end{array}$ \\
\hline
\end{tabular}

marine ecosystems include phytoplankton, periphyton, and macrophytes. Phytoplankton compose the predominant photosynthetic community in aquatic systems (Soler-López and Santos, 2010). Photosynthesis is the process of energy (food) generation for ecosystems through the conversion of carbon dioxide and water to glucose and oxygen. The process is controlled by factors such as light, temperature and nutrients (Dodd and Whiles, 2010). The chemical equation that describes the photosynthetic process and that is often used for describing primary productivity is

$$
6 \mathrm{CO}_{2}+6 \mathrm{H}_{2} \mathrm{O} \rightarrow \underset{\mathrm{C}_{6} \mathrm{H}_{12} \mathrm{O}_{6}+6 \mathrm{O}_{2}}{\text { Light }}
$$

Pigment receptor

where

$\mathrm{CO}_{2}$ is carbon dioxide;

$\mathrm{H}_{2} \mathrm{O}$ is a water molecule;

$\mathrm{C}_{6} \mathrm{H}_{12} \mathrm{O}_{6}$ is glucose; and

$\mathrm{O}_{2}$ is oxygen.

The three main processes controlling the primary productivity or production of organic matter are: (1) the net productivity, which accounts for the all carbon taken up during photosynthesis minus losses caused by respiration processes; (2) respiration, defined as the oxygen consumed by all community organisms; and (3) gross productivity, which accounts for all photosynthesis in the photoautotroph community of organisms - plants, algae, and cyanobacteria (Dodds and Whiles, 2010). Net productivity is equal to the gross productivity minus any loss of organic matter attributable to respiration.
Gross primary productivity and respiration processes were determined by measuring DO production during photosynthetic activity of phytoplankton (water column organisms) and bottom vegetation (seagrass), which represents the entire photosynthetic community of the lagoons. To distinguish between the two, oxygen produced by the entire community minus the oxygen produced by phytoplankton gives the oxygen produced by the bottom vegetation. The computed value of primary productivity is expressed in units of grams of oxygen per cubic meter per hour, and a factor of 0.375 is used to covert to carbon equivalents on the basis of the stoichiometry of the photosynthesis equation. The primary productivity estimates were made for the euphotic zone and assumed the primary productivity behavior is constant throughout the euphotic zone.

\section{Net Phytoplankton Primary Productivity}

Phytoplankton are unicellular algae that float in water and constitute the major energy producer in aquatic ecosystems (Wetzel, 2001). These single-celled plants have an important role in marine ecology because of their high potential of productivity, and they are considered as the first link in marine food chains (Karl and others, 2000). The standard light-dark method was used to determine the primary productivity of phytoplankton (Selvam and others, 1992). The method consists of the in-situ incubation of two light and dark bottles for approximately 4 hours. During this period, accumulation of oxygen occurs in the light (translucent) bottles owing to the photosynthesis process, while consumption of oxygen is 
expected in the dark bottles (nontranslucent). This method assumes respiration in the light bottles equals respiration in the dark bottles; thus, net changes in the concentration of DO can be estimated by comparing DO concentrations in light and dark bottles with the DO concentration in the initial bottle (chemically fixed to avoid oxygen saturation). The equations below present the calculations that were used to determine primary productivity:

$$
\begin{gathered}
P g=\frac{O L-O D}{t} \\
P n=\frac{O L-O I}{t} \\
R=\frac{O I-O D}{t}
\end{gathered}
$$

where

$\mathrm{Pg} \quad$ is gross productivity, in grams of oxygen per cubic meter per hour,

$P n \quad$ is net productivity, in grams of oxygen per cubic meter per hour,

$R \quad$ is respiration, in grams of oxygen per cubic meter per hour,

$O L$ is the DO concentration in the light bottle measured at the end of the incubation, in grams of oxygen per cubic meter,

$O D$ is the DO concentration measured in the dark bottle at the end of the incubation, in grams of oxygen per cubic meter,

$O I$ is the initial DO concentration measured prior to the incubation, in grams of oxygen per cubic meter and,

$t$ is the incubation time, in hours.

DO concentration was measured using the Winkler titration method, and incubation occurred by submerging two aluminum racks in water at $0.1 \mathrm{~m}$ depth, with a total of two dark and two light bottles per station (table 2).

\section{Net Community Primary Productivity}

The net community primary productivity represents the productivity attributable to all photosynthetic organisms, including organisms other than phytoplankton. Primary production by phytoplankton accounts for most of the production in marine ecosystems; thus, subtracting the net phytoplankton primary productivity from the net community primary productivity provides an estimate of production by other photosynthetic organisms, such as periphyton and macrophytes. Two diel studies were conducted during high and low tide conditions. The diel studies consisted of measuring selected water-quality parameters (DO, temperature, and percentage of oxygen saturation) hourly during a diurnal cycle. Similar to the light-dark bottle method, diel studies were conducted to estimate the net community primary productivity, the respiration rate, and the gross community primary productivity.

Estimates of community primary productivity were obtained by calculating the rate of change in DO throughout the diurnal cycle. This method assumes that positive values represent community primary productivity whereas negative values are indicative of community respiration. Net community primary productivity was calculated by summing the rate of change of DO measurements during daylight hours (Cornell and Klarer, 2008). Estimates of community respiration were calculated by summing the hourly rates of change in DO and then dividing by the number of nighttime hours.

The exchange of oxygen with the air (diffusion) was considered in the diel study, and each measurement of DO was corrected for diffusion prior to net productivity and respiration calculations as described by Odum (1956). The diffusion rate per volume $\left(\mathrm{gO}_{2} / \mathrm{m}^{3}-\mathrm{d}\right)$ is obtained by multiplying the gas transfer coefficient $\left(\mathrm{O}_{2} / \mathrm{m}^{3}-\mathrm{d}\right)$ by the saturation deficit between water and air. The equation used to describe the gas transfer coefficient $(k)$, in $\mathrm{O}_{2} / \mathrm{m}^{3}-\mathrm{d}$, is presented below:

$$
k=\frac{q_{m}-q_{e}}{\left(S_{m}-S_{e}\right) / 100 \text { percent }}
$$

where

$$
\begin{aligned}
& q_{m} \quad \text { is the rate of change in DO before sunrise } \\
& \text { (morning); } \\
& q_{e} \quad \text { is the rate of change in DO after sunset } \\
& \text { (evening); } \\
& S_{m} \quad \text { is the oxygen saturation deficit before sunrise } \\
& \text { in percent; and } \\
& S_{e} \quad \text { is the oxygen saturation deficit after sunset, in } \\
& \text { percent. }
\end{aligned}
$$

\section{Other Biological Health Indicators}

In aquatic ecosystems, algal biomass is commonly evaluated to assess water quality, because these organisms, especially the phytoplankton, are responsible for most of the photosynthetic process in an aquatic environment (Boyer and other, 2008). Measurements of algal biomass can provide useful information regarding the toxicity, nutrient enrichment, or other biological processes occurring in lakes or rivers. Several methods exist to measure phytoplankton biomass; the measurement of pigment is the easiest and most precise method (Billington, 1991). Chlorophyll $a$ is the most abundant photosynthetic pigment in organisms, and it is widely used as an indicator of algal biomass (Boyer and others, 2008). Phytoplankton biomass, also known as phytoplankton standing crop, is referred to as the weight or mass of phytoplankton present in the water column. 
In this study, algal biomass was determined by (1) quantifying chlorophyll $a$, and (2) measuring the ash-weight/dry-weight ratio to determine ash-free dry phytoplankton biomass (Britton and Greeson, 1988). Water samples were collected at two stations in each lagoon (figs. 2 and 3; table 2). The preprocessing of water samples included filtration through a glass fiber filter $(47-\mathrm{mm}$ pore size) and freezing of the filters prior to laboratory analysis at the USGS NWQL. Phytoplankton biomass was estimated using the ash-weight/dry-weight ratio method and is based on the residual of dried mass after organic matter in the sample has been removed by incineration (Britton and Greeson, 1989; American Public Health Association, 1995).

\section{Bacteriological Analysis}

Fecal coliform and enterococci are considered indicators of human waste, and are typically monitored in drinking water, in recreational waters, and in water bodies with high ecological value. The concentration of fecal coliforms and enterococci was determined in monthly water samples collected at two stations each in Puerto Mosquito on Isla de Vieques and in Caño Boquerón in Cabo Rojo (table 1; figs. 2 and 3). Water samples were collected using sterile borosilicate glass 100 milliliters $(\mathrm{mL})$ bottles with the hand-dip method. Sample volumes $(20,60$, and $100 \mathrm{~mL}$ of water) were filtered using 0.65 -micrometer $(\mu \mathrm{m})$ and 0.45 - $\mu \mathrm{m}$ pore-size filters for fecal coliform and enterococci analyses, respectively.

\section{Seawater Exchange}

Water exchange between the ocean and a lagoon is affected by the hydraulic characteristics of the inlet/outlet channel and by the primary forces driving ocean-lagoon exchange, such as tides and winds (Abigail and others, 2009). Several methods and techniques exist to measure the flushing rate or cycle of lagoons, and for this study, water-level fluctuations recorded at USGS gaging stations 50231500 (PM No. 1, Isla de Vieques) and 50129935 (CB No. 3, Cabo Rojo) were used to estimate the absolute volume change and, ultimately, the seawater exchange.

The unit values of recorded gage heights (recorded every 15 minutes) from July 18, 2015, to July 15, 2016, were used for the analysis. Each maximum and minimum gage height per tidal cycle was identified, and the time series (maximum and minimum gage heights values) was averaged, resulting in one daily maximum and minimum value per tidal cycle for the period of record. The difference between average maximum and average minimum water levels represents the average change in water level per tidal cycle for the lagoon during the period of record. To determine the change in water level per day, the change in water level per tidal cycle was divided by the average number of tides per day. Then, the storage volume associated with the change in water level per tidal cycle was obtained using the stage-storage curve generated with the 2015 bathymetric survey. An estimate of water exchange between ocean and lagoon was assumed to be the percentage of the total storage volume of the lagoon associated with the water-level change.

\section{Sediment Core Collection and Analysis}

Sediment transport processes along coastal lagoons contribute to the formation and perpetuation of inland waters (Abigail and others, 2009). Documentation of sediment deposition rates at a lagoon provides useful information for better understanding of sedimentation processes that may result in the loss of water depth in the lagoon. To determine the sediment deposition rate in each lagoon, several sediment core samples were collected at one site in Caño Boquerón and at one site in Puerto Mosquito on December 2, 2015, and January 21, 2016, respectively. Selection of representative sediment core collection sites (figs. 2 and 3; table 1 CB No. 2 and PM No. 5) was based on bathymetric information. Five cores (1-m long and 5.1-centimeter [cm] diameter) were collected using a sediment sampler deployed from a boat. The boat was positioned at the chosen site using a Global Positioning System device, and the corer was forced vertically through the bottom of the lagoon up to the point that the corer reached its maximum depth of penetration. After retrieval of the corer, the liner was extracted and the core was capped on top and bottom.

Once collected, the cores were stored vertically for 1-2 weeks to allow them to dry. After drying, a plunger was used to remove the liner; the core was cut at 2-cm intervals to create samples that weighed 50 grams each. A single composite sample representing a 2-cm layer was obtained by combining the corresponding 2-cm subsamples from each core in a wide-mouth polypropylene jar. Approximately 20 composited samples from each core were collected and sent to the USGS NWQL for radioisotope analysis.

The radioisotope cesium-137 $\left({ }^{137} \mathrm{Cs}\right)$ is a byproduct of nuclear fission processes in nuclear weapons, mostly from tests conducted in the $1950 \mathrm{~s}$. The half-life of ${ }^{137} \mathrm{Cs}$ is about 30 years, and it is widely used as a tracer of sedimentation because the radioisotope does not occur naturally (Ritchie and McHenry, 1990). Radioisotopes are present in lagoon sediments mostly through atmospheric processes, which produce fine sediment that eventually is transported via runoff into water bodies (Soler-López and Santos, 2010). Accordingly, sediment layers that were deposited during the intense nuclear testing of the 1950s have relatively high radioisotope activity. Nuclear weapons testing first occurred in 1952, so this time marker can be used for dating purposes. Because of travel time in the atmosphere, the radioisotope ${ }^{137} \mathrm{Cs}$ lags up to 2 years behind the test dates prior to deposition within sediments; therefore, 1954 is assigned as the year of first occurrence instead of 1952 (Ritchie and McHenry, 1990).

Natural uranium-238 decays to radon-222, a natural gas in the atmosphere; radon subsequently decays to 
lead-210 $\left({ }^{210} \mathrm{~Pb}\right)$, a radioisotope that has a half-life of 22.3 years. Hypothetically, in a scenario in which the sedimentation rates in a water body and the radioisotope ${ }^{210} \mathrm{~Pb}$ fluxes are constant, sediment can be dated by assuming a decrease in ${ }^{210} \mathrm{~Pb}$ with depth by a factor of 2 every 22.3 years.

\section{Results and Discussion}

The monthly water sampling at Caño Boquerón and Puerto Mosquito allowed for evaluation of spatial and temporal variations in the water-quality and hydrologic conditions. These lagoons were previously considered to be unmonitored coastal waters (Puerto Rico Environmental Quality Board, 2014a); prior to this study, no baseline information was available to evaluate human impacts, so the results of this investigation provide valuable information on the presence of contamination.

\section{Bathymetry}

The bathymetric surveys conducted at Caño Boquerón and Puerto Mosquito in August 2015 generated bathymetric maps showing bottom contours referenced to mean sea level. The bathymetric maps were used to estimate the storage volumes of the two lagoons. The spatial data associated with the bathymetric survey are available in Gómez-Fragoso and Santiago-Sáez (2018).

The water depths at Caño Boquerón ranged between 0.5 and $5.5 \mathrm{~m}$, and the water volume was estimated at 967,000 cubic meters $\left(\mathrm{m}^{3}\right)$ at mean sea level. The mean depth of the lagoon was $1.5 \mathrm{~m}$ below mean sea level. A deeper area corresponding to a dredged channel constructed for navigation was measured from the mouth of the lagoon to a dock near CB No. 3 (fig. 2). Bottom contours of Caño Boquerón are referenced to mean sea level based on water-level data from USGS gaging station 50129935 (CB No. 3) (fig. 4).

Water depths at Puerto Mosquito were adjusted using the stage records from USGS 50231500 (PM No. 1). The bottom of the lagoon had an average depth of about $1.8 \mathrm{~m}$ and depths ranged from 0.5 to $5 \mathrm{~m}$ (fig. 5). The bottom of the lagoon is cone-shaped, with the deepest part near PM No. 5 (fig. 3). The estimated water volume of Puerto Mosquito lagoon at mean sea level is $1,182,200 \mathrm{~m}^{3}$.

\section{Rainfall Data Collection and Surface Water}

Daily rainfall data were collected at CB No. 3 (USGS station number 50129935) in Cabo Rojo. The total rainfall recorded at CB No. 3 from July 1, 2015, to June 30, 2016 (fig. 6) was $811 \mathrm{~mm}, 408 \mathrm{~mm}$ less than the 1981-2010 annual average reported by NOAA at Lajas Substation weather station (ID 66-5,097), which is near the study area. The highest total monthly rainfall during the study period was recorded in October $2015(143 \mathrm{~mm})$ and June $2016(102 \mathrm{~mm})$; the highest daily rainfall occurred in June 2016. The Lajas Substation weather station recorded total rainfall of about $823 \mathrm{~mm}$ for the same period.

The total rainfall recorded at PM No. 1 (USGS station number 50231500) in Puerto Mosquito was about $850 \mathrm{~mm}$ from July 1, 2015, to June 30, 2016 (fig. 7). Comparison of the total rainfall recorded at PM No. 1 and NOAA Roosevelt Roads weather station (ID 66-8,412), which is the closest station with historical data, indicated that the annual average rainfall at the latter station is $479 \mathrm{~mm}$ greater than at PM No. 1 . The highest total monthly rainfall was recorded in November $2015(151 \mathrm{~mm})$ and May $2016(110 \mathrm{~mm})$.

The rainfall/runoff ratio developed by Giusti and López (1967) was used to determine the annual runoff into the lagoons. For Caño Boquerón, the rainfall/runoff ratio based on the climatic index is 0.12 , and the total rainfall was $811 \mathrm{~mm}$ for July 2015 to June 2016, yielding a runoff depth of $97 \mathrm{~mm}$. The drainage area contributing to Caño Boquerón is $71.19 \mathrm{~km}^{2}$, and therefore, the annual runoff is estimated to be 6.91 million cubic meters per year $\left(\mathrm{Mm}^{3} / \mathrm{yr}\right)$, which is 9.9 times greater than the storage volume of the lagoon. For Puerto Mosquito, the rainfall/runoff ratio based on the climatic index is 0.45 (Giusti and López, 1967), which corresponds to a runoff depth of $382.5 \mathrm{~mm}$ for the rainfall measured from July 2015 to June $2016(850 \mathrm{~mm})$. Multiplying the runoff depth by the contributing drainage area of $48.49 \mathrm{~km}^{2}$ indicates that the annual runoff is about $18.65 \mathrm{Mm}^{3} / \mathrm{yr}$, which is 15.8 times higher than the storage volume of the lagoon.

\section{Water Quality}

\section{Temperature}

Water temperature has a substantial impact on metabolic processes, oxygen solubility, and aquatic life (Minnesota Control Pollution Agency, 2009). Temperature varies seasonally, which contributes to the variability in nutrient exchange in coastal waters (Jamila and others, 2016).

The water temperature at the surface ranged from 26.3 to 30.3 degrees Celsius $\left({ }^{\circ} \mathrm{C}\right)$ at Caño Boquerón in Cabo Rojo; the minimum temperatures were measured at CB No. 1 and CB No. 2 on January 26, 2016, and the maximum temperature was measured at CB No. 3 on July 6, 2016. The average surface temperature for the entire lagoon was $28.3^{\circ} \mathrm{C}$. All temperature measurements within the lagoon were below PREQB standards (temperature should not exceed $32.3^{\circ} \mathrm{C}$ ). Negligible vertical variability was observed in the lagoon; water temperature at the bottom of the lagoon ranged from 26.2 to $30.7^{\circ} \mathrm{C}$.

For Puerto Mosquito on Isla de Vieques, temperatures ranged from 26.1 to $30.9{ }^{\circ} \mathrm{C}$ and from 26.3 to $31.7^{\circ} \mathrm{C}$ at the surface and bottom of the lagoon, respectively. Maximum and minimum temperatures (at the surface) were recorded at PM No. 6 on September 9, 2015, and February 2, 2016, respectively. The average temperature for Puerto Mosquito was $28.6{ }^{\circ} \mathrm{C}$. There are no regulatory limits for temperature for Class SA lagoons. 


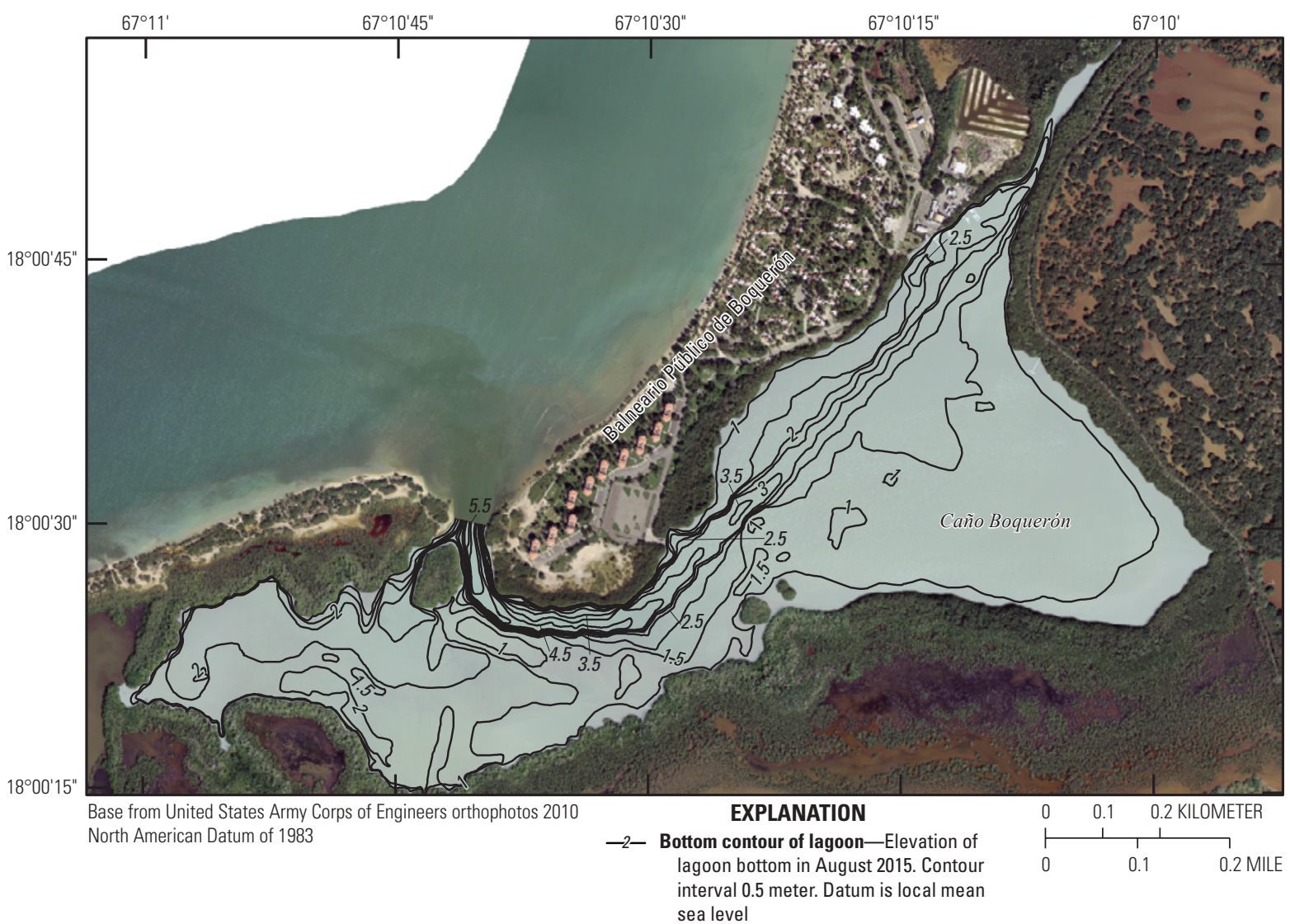

Figure 4. Bathymetry of Caño Boquerón, Cabo Rojo, Puerto Rico, August 2015.

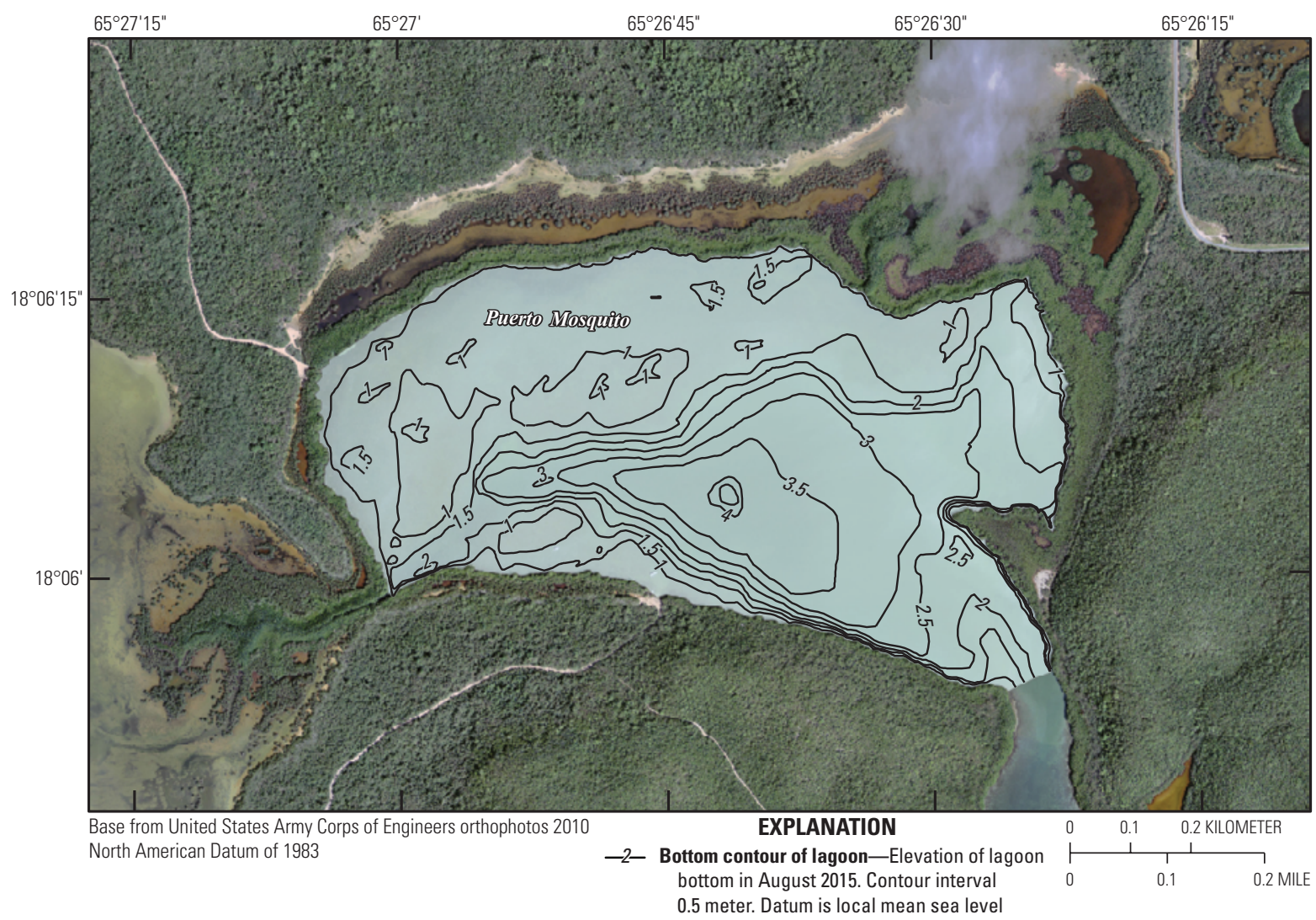

Figure 5. Bathymetry of Puerto Mosquito, Isla de Vieques, Puerto Rico, August 2015. 


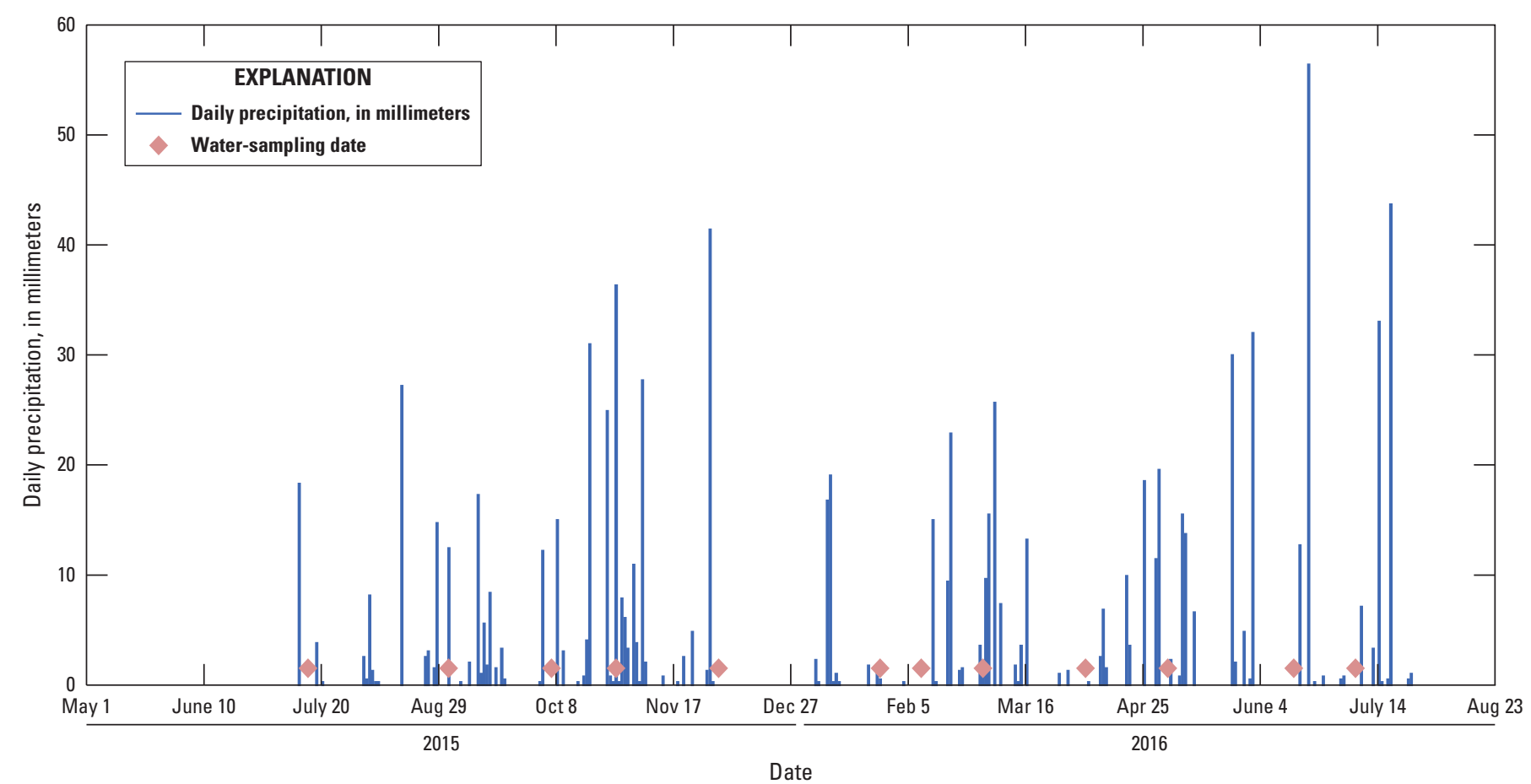

Figure 6. Daily rainfall collected at CB No. 3, Caño Boquerón, Cabo Rojo, Puerto Rico, July 1, 2015 to July 28, 2016.

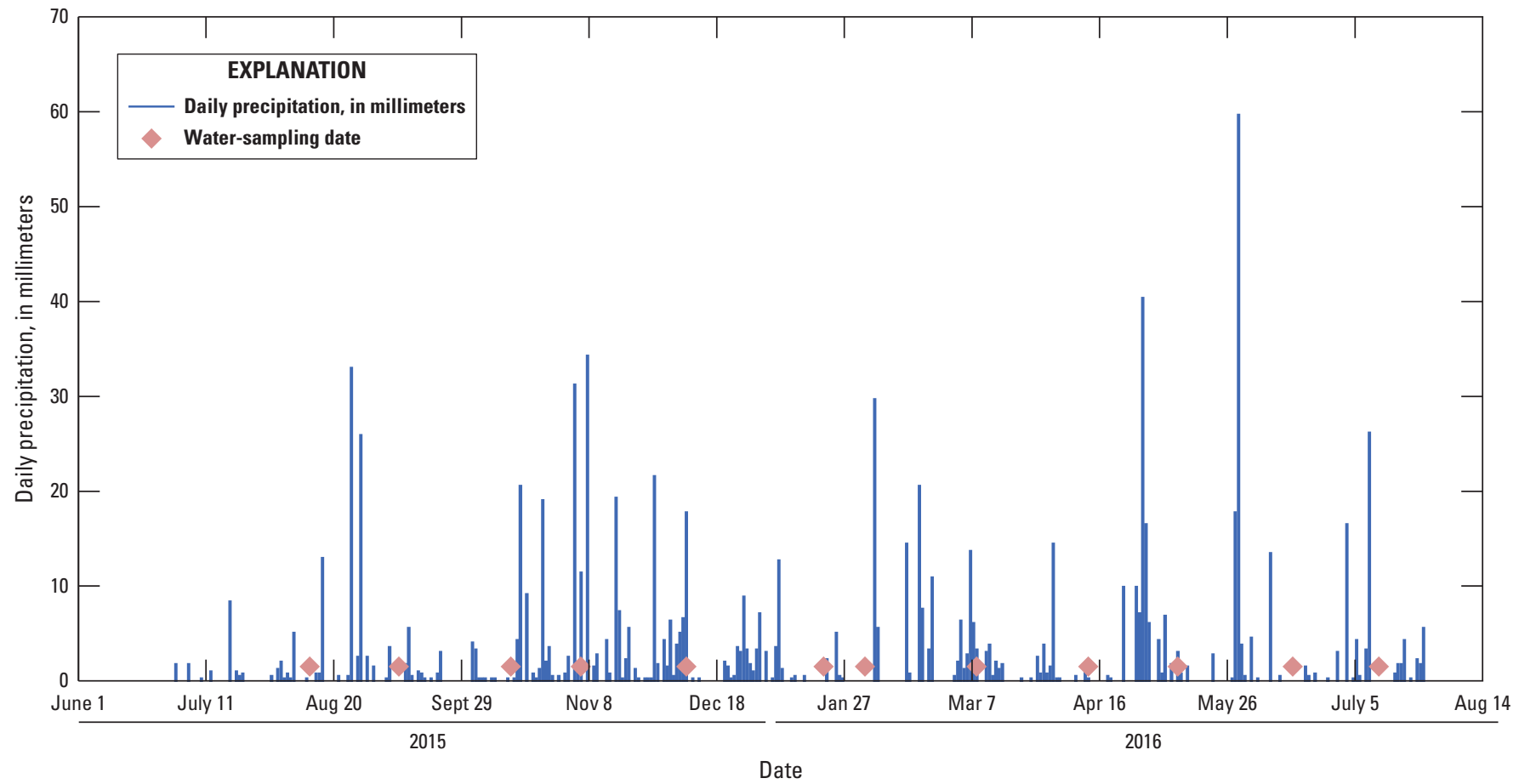

Figure 7. Daily rainfall collected at PM No. 1, Puerto Mosquito, Isla de Vieques, Puerto Rico, July 1, 2015 to July 28, 2016. 


\section{Turbidity}

Turbidity is defined as a measurement of the effect of suspended particles on the clarity of water (Wetzel, 2001). Water-quality deterioration associated with sediment transport, in-stream flow, and high levels of plant productivity can be assessed by measuring turbidity. The monitoring of turbidity is important because light penetration of the water column affects biological processes and DO concentrations in inland waters (Department of Environmental Conservation, 2015). As established by PREQB, turbidity in coastal waters (Class SB) must not exceed 10 nephelometric turbidity units (NTU). Turbidity results presented in this report correspond to water samples collected at the surface of the lagoon.

Turbidity at Caño Boquerón ranged from 4.1 to 10.4 NTU at station CB No. 1 and averaged 6.7 NTU (table 3). Turbidity ranged from 5.1 to $12.6 \mathrm{NTU}$ at station $\mathrm{CB}$ No. 2 and averaged 8.7 NTU. Turbidity was generally within PREQB standards, although the highest turbidity measurement at $\mathrm{CB}$ No. 2 (12.6 NTU on September 1, 2015) exceeded PREQB standards. Although precipitation data recorded at CB No. 3 indicated that a rainfall event occurred on September 1, 2015 (fig. 6), records with higher rainfall also coincided with below average turbidity values. No specific factors contributing to elevated turbidity were identified; however, potential factors such as runoff from the Lajas irrigation canal and adjacent areas and navigation activities may contribute.

Turbidity values are much lower at Puerto Mosquito compared to average turbidity values measured for Caño Boquerón. Average turbidity recorded at Puerto Mosquito was about 2.6 NTU at PM No. 2 and 3.0 NTU at PM No. 7.
Turbidity measurements ranged from $<2.0$ (value below detection limit) to $3.2 \mathrm{NTU}$ at PM No. 2, and from $<2.0$ to $5.5 \mathrm{NTU}$ at PM No. 7. Higher turbidity values were observed in the spring months (March and April). Less frequent boat traffic and less urban development within the Puerto Mosquito drainage basin likely result in lower turbidity at Puerto Mosquito than at Caño Boquerón.

\section{$\mathrm{pH}$}

Typical $\mathrm{pH}$ values in many coastal lagoons range from 7.9 to 8.2 (Menéndez and others, 2001). The PREQB established a range for $\mathrm{pH}$ of 7.3 to 8.5 in coastal lagoons under Class SB. Both natural and human factors may affect $\mathrm{pH}$ in inland waters, and it is widely used as an indicator of water quality because of its effects on the solubility of chemical constituents in water and on the availability of nutrients (Gonenc and Wolflin, 2005).

In Caño Boquerón, the average $\mathrm{pH}$ value at the surface was 7.9 and $\mathrm{pH}$ ranged from 7.3 to 8.1, which is in compliance with PREQB standards. The highest $\mathrm{pH}$ value (8.1) at the surface of the lagoon was recorded at CB No. 5 (50129960), and the minimum (7.3) was recorded at CB No. 2 (50129945). Measurements of $\mathrm{pH}$ in bottom waters of the lagoon ranged from 7.7 to 8.1, and averaged 7.9.

Field measurements of $\mathrm{pH}$ at Puerto Mosquito ranged from 7.6 to 8.1 , and the average $\mathrm{pH}$ for all stations was 7.9. The lowest $\mathrm{pH}$ was recorded at PM No. 2 (50231510). There was negligible vertical variation in $\mathrm{pH}$ in the water column of the lagoon. There are no PREQB standards for $\mathrm{pH}$ for Class SA water bodies.

Table 3. Results of turbidity analysis at Caño Boquerón, Cabo Rojo, and Puerto Mosquito, Isla de Vieques, Puerto Rico.

[Values are in nephelometric turbidity units (NTU); CB, Caño Boquerón; number in parentheses is the U.S. Geological Survey station identification number; PM, Puerto Mosquito; <, below the analysis detection limit]

\begin{tabular}{|c|c|c|c|c|c|c|}
\hline $\begin{array}{c}\text { Sampling } \\
\text { number }\end{array}$ & Date & $\begin{array}{c}\text { CB No. } 1 \\
(50129950)\end{array}$ & $\begin{array}{c}\text { CB No. } 2 \\
\text { (50129945) }\end{array}$ & Date & $\begin{array}{c}\text { PM No. } 2 \\
(50231510)\end{array}$ & $\begin{array}{c}\text { PM No. } 7 \\
\text { (50231502) }\end{array}$ \\
\hline 1 & July 15,2015 & 6.1 & 6.3 & Aug. 12, 2015 & $<2.0$ & 3.7 \\
\hline 3 & Oct. 6, 2015 & 4.7 & 5.1 & Oct. 14,2015 & $<2.0$ & $<2.0$ \\
\hline 4 & Oct. 28,2015 & 7.7 & 8.0 & Nov. 5, 2015 & $<2.0$ & 2.2 \\
\hline 7 & Feb. 9, 2016 & 4.9 & 8.1 & Feb. 2, 2016 & 2.1 & 3.0 \\
\hline 8 & Mar. 1, 2016 & 10.4 & 11.4 & Mar. 8, 2016 & 3.0 & 5.5 \\
\hline 9 & Apr. 5, 2016 & 6.9 & 6.8 & Apr. 12, 2016 & 3.2 & 3.5 \\
\hline 10 & May 3, 2016 & 10.3 & 9.8 & May 10, 2016 & 2.8 & 2.1 \\
\hline
\end{tabular}

${ }^{1}$ Averages for sites that included values of $<2.0$ were calculated by substituting the highest possible value below the detection limit (1.99 NTU) and therefore are reported with the less than or equal to (“’”) symbol. 


\section{Dissolved Oxygen Concentration}

Several physicochemical parameters influence DO concentration. The variability in DO concentration influences biological processes such as photosynthesis, respiration, and decomposition (Jamila and others, 2016). Low DO concentrations may lead to ecosystem impairment, slowed growth rates, and toxicity of water (O'Boyle and others, 2009). As noted earlier, DO concentration can be correlated with other physicochemical parameters, such as turbidity and biological activity, because less light penetration as a result of high turbidity has a direct effect on photosynthesis processes and eventually the productivity of aquatic ecosystems, which ultimately leads to lower DO concentrations.

The DO concentrations at the surface of both lagoons were generally greater than 5 milligrams per liter $(\mathrm{mg} / \mathrm{L})$, which is the PREQB standard. The average DO concentration at the surface at Caño Boquerón was $4.9 \mathrm{mg} / \mathrm{L}$. Of the five stations at Caño Boquerón, only CB No. 3 had an average surface DO concentration lower than $5 \mathrm{mg} / \mathrm{L}$; the other four stations had an average DO concentration greater than $5 \mathrm{mg} / \mathrm{L}$. The maximum DO concentration $(6.0 \mathrm{mg} / \mathrm{L})$ was measured at CB No. 5 and occurred at both the surface and the bottom of the lagoon. The lowest DO concentration $(3 \mathrm{mg} / \mathrm{L}$ at the surface; $2.3 \mathrm{mg} / \mathrm{L}$ at the bottom) was measured at station CB No. 3, which is the station located at the dock structure. The DO concentration at the bottom of the lagoon averaged $4.5 \mathrm{mg} / \mathrm{L}$, and ranged from 2.3 to $6 \mathrm{mg} / \mathrm{L}$.

Puerto Mosquito had slightly higher DO concentrations, compared to Caño Boquerón, with an average DO concentration at the surface of about $5.4 \mathrm{mg} / \mathrm{L}$. The DO concentrations during the study ranged from 4.1 to $6.2 \mathrm{mg} / \mathrm{L}$ at the surface and from 2.5 to $6.0 \mathrm{mg} / \mathrm{L}$ at the bottom of the lagoon. Maximum and minimum DO concentrations were measured at PM No. 5 on February 2, 2016, and PM No. 4 on November 5, 2015, respectively.

\section{Specific Conductance}

Specific conductance is defined as the measurement of the ability of the water to conduct an electric current (Soler-López and Santos, 2010), typically referenced to $25^{\circ} \mathrm{C}$ to account for temperature dependence. Specific conductance can be used to assess water quality because it is an indicator of the amount of dissolved solids in water, which may help identify possible disturbances in the watershed that affect the water body. No specific standards have been established by PREQB regarding specific conductance. Specific conductance in both lagoons was greatly influenced by the influx of ocean water, which typically has a specific conductance of $53,200 \mu \mathrm{S} / \mathrm{cm}$ at $25^{\circ} \mathrm{C}$ (Horne, 1969). Specific conductance values greater than $53,200 \mu \mathrm{S} / \mathrm{cm}$ at $25^{\circ} \mathrm{C}$ are possible because of density gradients and localized variations in ocean salinity (NASA Earth Observations, 2017) as well as from enhanced evaporation within the lagoons under warm, semi-arid conditions.
Average specific conductance at the surface of Caño Boquerón was about $53,700 \mu \mathrm{S} / \mathrm{cm}$ at $25^{\circ} \mathrm{C}$. Low spatial variability was observed throughout the lagoon, but seasonal variations occurred, which were indicated by a minimum specific conductance at the surface of $51,300 \mu \mathrm{S} / \mathrm{cm}$ at $25^{\circ} \mathrm{C}$ on December 2, 2015, at CB No. 4, and a maximum specific conductance of $56,900 \mu \mathrm{S} / \mathrm{cm}$ at $25^{\circ} \mathrm{C}$ on June 15,2016 , at CB No. 2 and CB No. 4. The minimum specific conductance coincided with a rainfall event of about $38 \mathrm{~mm}$, which occurred about 3 days before water sampling (fig. 6). Specific conductance at the bottom of the lagoon averaged about $54,100 \mu \mathrm{S} / \mathrm{cm}$ at $25^{\circ} \mathrm{C}$, slightly greater than at the surface of the lagoon. Seasonal patterns in specific conductance were observed during the study; values were generally lower in November-December, and higher in June-July (fig. 8).

Specific conductance measurements at Puerto Mosquito also indicated seasonal variations but were relatively spatially homogenous throughout the lagoon (fig. 8). The average specific conductance was about $55,400 \mu \mathrm{S} / \mathrm{cm}$ at $25^{\circ} \mathrm{C}$ at the surface and $55,800 \mu \mathrm{S} / \mathrm{cm}$ at $25^{\circ} \mathrm{C}$ at the bottom. The maximum specific conductance at the surface was $57,700 \mu \mathrm{S} / \mathrm{cm}$ at $25^{\circ} \mathrm{C}$ on August 12, 2015, at PM No. 4. The maximum specific conductance at the bottom was $68,000 \mu \mathrm{S} / \mathrm{cm}$ at $25^{\circ} \mathrm{C}$ at PM No. 5 on August 12, 2015. The lowest specific conductance at the bottom was $51,800 \mu \mathrm{S} / \mathrm{cm}$ at $25^{\circ} \mathrm{C}$ on December 8, 2015, at PM No. 7 . The low specific conductance likely occurred as a result of several rainfall events in the days immediately before water sampling on December 8. Vertical variability was observed in field measurements of specific conductance collected on August 12, 2017; there was a difference in specific conductance between the surface and the bottom of the lagoon of about $10,000 \mu \mathrm{S} / \mathrm{cm}$ at $25{ }^{\circ} \mathrm{C}$. This vertical variability in the specific conductance measurements was observed at stations PM No. 2 and PM No. 5, which are in the deeper areas of the lagoon. A substantial difference in temperature measurements (about $2.4{ }^{\circ} \mathrm{C}$ ) between the surface and the bottom of the lagoon also occurred at these two sites.

\section{Salinity}

Salinity is a measure of dissolved salts in water; its variability in impounded waters is influenced by the drainage basin inflows (Wetzel, 2001). Measurements of salinity in coastal lagoons provide valuable information regarding the hydrologic and climatic conditions influencing these ecosystems (Herrera-Silveira, 1996). Changes in salinity are often associated with in-stream runoff, groundwater interactions, and dry/wet seasons. Exchange with seawater is another factor governing salinity in coastal waters, and typical salinity values range between 35 and 40 parts per thousand (ppt) in Puerto Rico (Soler-López and Santos, 2010).

Salinity measured at Caño Boquerón indicated negligible vertical stratification; salinity averages at the surface and the 

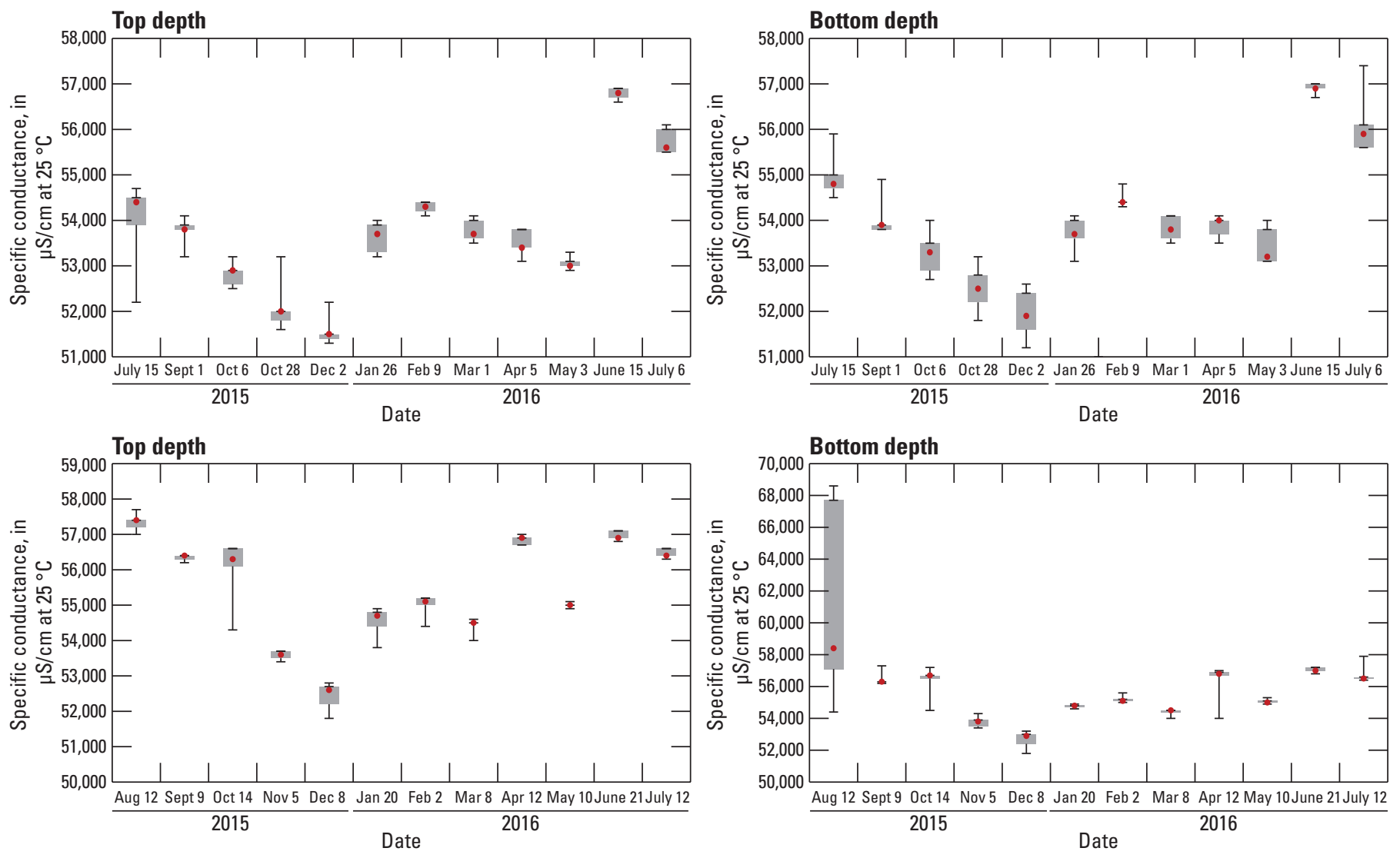

\section{EXPLANATION}

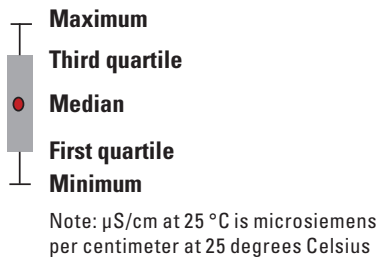

Figure 8. Specific conductance measurements at Caño Boquerón, Cabo Rojo, and Puerto Mosquito, Isla de Vieques, Puerto Rico, from July 2015 to July 2016.

bottom of the lagoon were 35.5 and $35.6 \mathrm{ppt}$, respectively. As noted earlier, specific conductance is an indirect measure of salinity in waters; therefore, stations with maximum and minimum measurements of specific conductance also had maximum and minimum salinity. Variations in salinity were observed during the period of record, ranging from 33.6 to $37.7 \mathrm{ppt}$ at the surface and from 31.7 to $38.1 \mathrm{ppt}$ at the bottom of the lagoon.

The average salinity at Puerto Mosquito was $36.6 \mathrm{ppt}$ near the surface and $36.9 \mathrm{ppt}$ near the bottom. Although salinity near the surface ranged between 34.0 and $38.4 \mathrm{ppt}$, indicating temporal variations during the period of record, vertical stratification was generally absent or slight, with the exception of measurements on August 12, 2015, at LPBM No. 2 and LPBM No. 5. Salinity standards have not been established by PREQB.

\section{Water Transparency}

Water transparency is a measure of the depth to which sunlight can penetrate the water. The typical instrument used to measure water transparency is the Secchi disk. The $20-\mathrm{cm}$ diameter disk, which is marked with four black and white quadrants, is submerged in water to increasing depths until the color difference between quadrants is no longer distinguishable. Water transparency is calculated by multiplying the water depth at which the color difference between quadrants of the Secchi disk is no longer distinguishable by at least 1.7 (Scheffer, 2004). Water transparency is used to define the euphotic zone, which is the depth of sunlight penetration, and it can be affected by natural (incident solar radiation, rainfall, runoff, decomposing material among others) or manmade (pollution loading) conditions. No PREQB standard exists regarding water transparency in coastal waters. 
Average water transparency for Caño Boquerón was $100 \mathrm{~cm}(1.0 \mathrm{~m})$ and ranged from 52 to $233 \mathrm{~cm}$. The results indicate that average water transparency $(1.0 \mathrm{~m})$ is less than the mean depth of the lagoon $(1.5 \mathrm{~m})$. The highest water transparency occurred at CB No. 3, and negligible temporal variations were observed throughout the period of record.

Water transparency measured at Puerto Mosquito ranged from 104 to $389 \mathrm{~cm}$. Negligible seasonal variations were observed; however, higher transparency values were noted at stations PM No. 2, PM No. 5, and PM No. 6, which are located closer to the mouth of the lagoon (fig. 3). The water transparency average was $187 \mathrm{~cm}(1.87 \mathrm{~m})$, which is slightly greater than the mean depth of the lagoon $(1.8 \mathrm{~m})$. For sampling events with water transparency depths greater than the depth of the lagoon, results can be interpreted to mean that the photic zone extends to the bottom of the lagoon.

\section{Nutrients}

Nutrient assessments in coastal lagoons are widely used to evaluate the potential occurrence and adverse effects of high nutrient concentrations. Pristine water bodies in remote areas are often oligotrophic, containing very low concentrations of nutrients. Many coastal lagoons are mesotrophic, having moderate nutrient concentrations, whereas others subjected to nutrient runoff from intense development or agriculture become eutrophic. Eutrophication, or nutrient enrichment, may lead to the occurrence of algal blooms. Nutrients are a limiting factor in the primary production of aquatic ecosystems, and the vulnerability of lagoons to eutrophication can be substantial because of natural and (or) human factors (Thomaz and others, 2001).
Water samples were collected at both Caño Boquerón and Puerto Mosquito for analysis of nutrients, with emphasis on the concentrations of total dissolved nitrogen and phosphorus. Total nitrogen and phosphorous concentrations for Caño Boquerón averaged $0.24 \mathrm{mg} / \mathrm{L}$ as nitrogen $(\mathrm{N})$ and $0.029 \mathrm{mg} / \mathrm{L}$ as phosphorus (P), respectively (tables 4 and 5). Total nitrogen concentrations ranged from 0.16 to $0.25 \mathrm{mg} / \mathrm{L}$ as $\mathrm{N}$ at CB No.1 and ranged from 0.15 to $0.45 \mathrm{mg} / \mathrm{L}$ as $\mathrm{N}$ at CB No.2. Concentrations of total phosphorous at $\mathrm{CB}$ No. 1 ranged from 0.017 to $0.034 \mathrm{mg} / \mathrm{L}$ as $\mathrm{P}$, with a mean concentration of $0.024 \mathrm{mg} / \mathrm{L}$ as P. At CB No. 2, average phosphorous concentrations were $0.034 \mathrm{mg} / \mathrm{L}$ as $\mathrm{P}$ and ranged from 0.025 to $0.054 \mathrm{mg} / \mathrm{L}$ as $\mathrm{P}$. Total nitrogen and phosphorous concentrations at Caño Boquerón were substantially below PREQB standards, which are 5 and $1 \mathrm{mg} / \mathrm{L}$, respectively. These low total phosphorus concentrations are typical of highly productive coastal ecosystems because phosphorus is a limiting nutrient; whenever it is available, it is rapidly taken up by photosynthetic organisms.

Average concentrations of total nitrogen and phosphorous at Puerto Mosquito were 0.24 and $0.017 \mathrm{mg} / \mathrm{L}$, respectively. The range of total nitrogen concentrations measured at the stations at Puerto Mosquito was small, which indicates a low spatial variability throughout the lagoon. The minimum total nitrogen concentration at both stations was $0.19 \mathrm{mg} / \mathrm{L}$, and the maximum concentrations were 0.32 and $0.30 \mathrm{mg} / \mathrm{L}$ at PM No. 2 and PM No. 7, respectively. Some phosphorous concentrations were below the method detection limit of $0.004 \mathrm{mg} / \mathrm{L}$ during the sampling period. The average concentrations of phosphorus were 0.0018 and $0.017 \mathrm{mg} / \mathrm{L}$ at PM No. 2 and PM No. 7 , respectively. There are no standards established by PREQB for total nitrogen and phosphorous for Class SA lagoons.

Table 4. Total nitrogen concentrations from unfiltered samples collected at selected sites at Caño Boquerón, Cabo Rojo, and Puerto Mosquito, Isla de Vieques, Puerto Rico.

[Concentrations in milligrams per liter (mg/L); CB, Caño Boquerón; number in parentheses is the U.S. Geological Survey station identification number; PM, Puerto Mosquito]

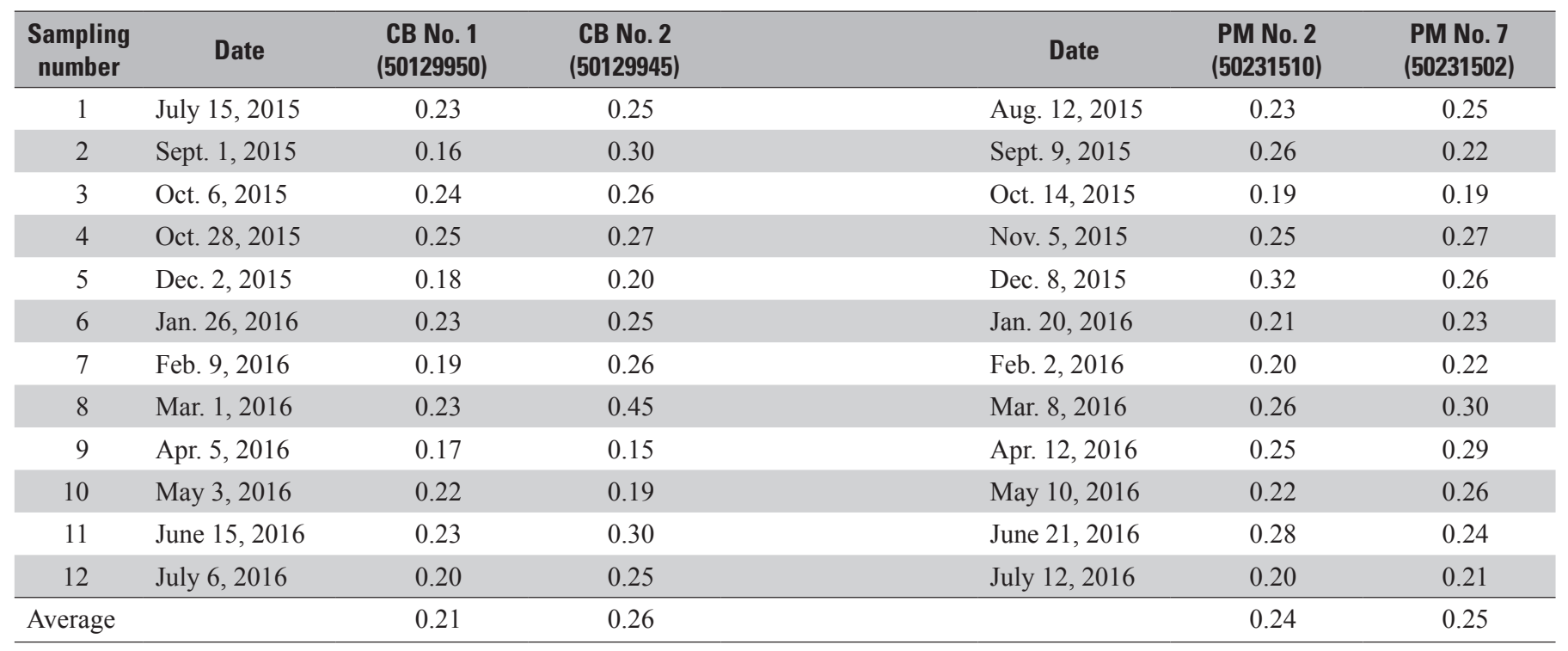




\section{Cross-Sectional Profiles of Physicochemical Properties at Puerto Mosquito on Isla de Vieques}

Additional physicochemical characteristics were measured at Puerto Mosquito in Isla de Vieques on June 16, 2016. A cross-sectional profile of temperature, specific conductance, and DO concentration measurements was developed for Puerto Mosquito. Measurements were made during the morning at selected locations (fig. 9). The main objective was to assess the spatial variation of physicochemical characteristics that may affect the water-quality processes in Puerto Mosquito, which is one of three prominent bioluminescent bays in Puerto Rico.

The DO concentrations ranged from 4.6 to $6.0 \mathrm{mg} / \mathrm{L}$ (fig. 10). The cross-sectional profile represents a snapshot of spatial variations in $\mathrm{DO}$ concentration throughout the lagoon and indicates that DO concentrations are homogenous until about $4 \mathrm{~m}$ below the water surface; below $4 \mathrm{~m}$, the DO concentrations begin to decrease. A comparison of the DO concentrations in the shallow and deep areas of the lagoon indicates less stratification in shallow zones compared to deeper zones. The maximum DO concentrations along the profile were measured at collection point 7 , which is near PM No. 1 where the bottom is quite shallow (figs. 5, 10).

A cross-sectional profile of specific conductance also was determined (fig. 11). The shoreline areas had specific conductance values of about $57,600 \mu \mathrm{S} / \mathrm{cm}$ at $25^{\circ} \mathrm{C}$; the lowest specific conductance values $\left(56,900 \mu \mathrm{S} / \mathrm{cm}\right.$ at $\left.25^{\circ} \mathrm{C}\right)$ were measured in the center of the lagoon near collection points 3,4 , and 5 (fig. 8 ) in water depths of as much as $3.5 \mathrm{~m}$.

\section{Biological Characteristics}

Primary productivity, phytoplankton biomass, and bacteriological analyses composed the biological assessment of Caño Boquerón and Puerto Mosquito. Primary productivity by phytoplankton was determined using monthly in-situ incubation with the light and dark bottles method, and diurnal variation in $\mathrm{DO}$ concentration was evaluated to determine primary benthic productivity. DO concentration, temperature, and $\mathrm{pH}$ were measured during diel studies conducted at Caño Boquerón and Puerto Mosquito (Gomez-Fragoso and Santiago-Sáez, 2018). Water sampling and analyses to identify fecal coliform and enterococci bacteria were conducted to detect potential fecal contamination at both lagoons.

\section{Primary Productivity}

As noted earlier in the report, analysis of primary productivity can be used to indicate trophic status of coastal waters. The analysis was divided into two components: (1) phytoplankton primary productivity, which is the major producer in aquatic ecosystems, and (2) community primary productivity, which accounts for primary productivity within the entire community of organisms (phytoplankton, cyanobacteria and benthos) and may be a major producer locally.

Table 5. Phosphorous concentrations from unfiltered samples collected at selected sites at Caño Boquerón, Cabo Rojo, and Puerto Mosquito, Isla de Vieques, Puerto Rico.

[Concentrations in milligrams per liter (mg/L); CB, Caño Boquerón; number in parentheses is the U.S. Geological Survey station identification number; PM, Puerto Mosquito; <, below analysis detection limit]

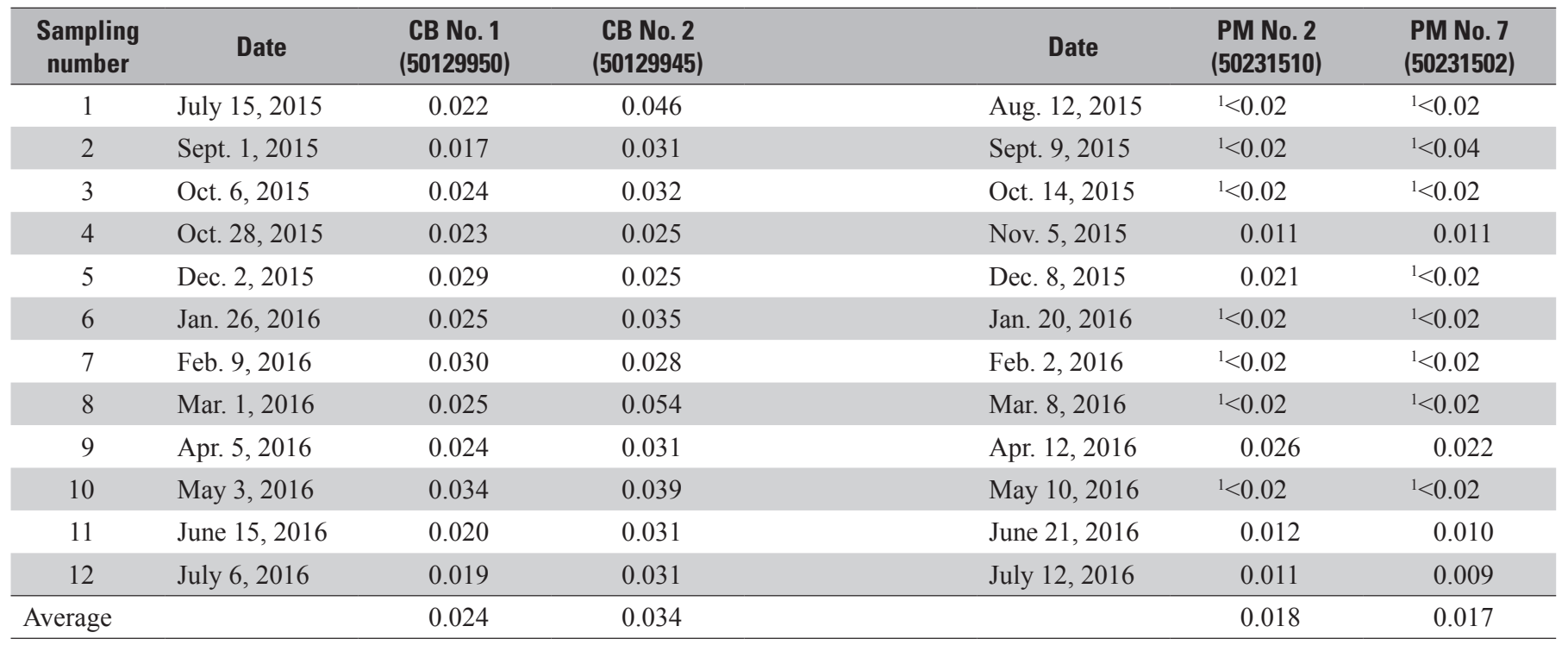

${ }^{1}$ Averages for sites that included values of $<0.02$ were calculated by substituting the highest possible value below the detection limit $(0.019$ nephelometric turbidity units) and therefore are reported with the less than or equal to $(\leq)$ symbol. 


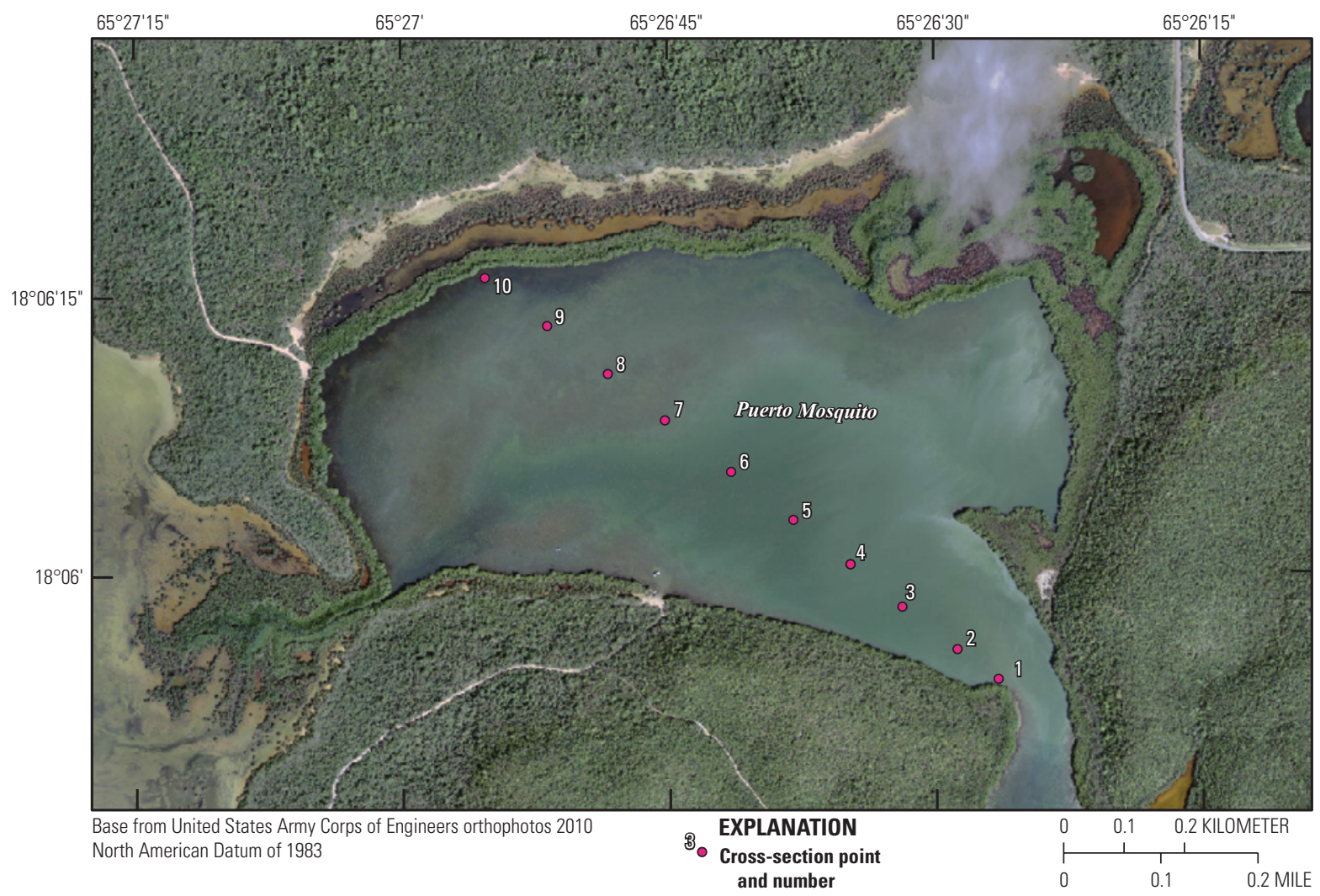

Figure 9. Location of points along a cross-sectional profile where water-quality measurements were collected at Puerto Mosquito, Isla de Vieques, Puerto Rico, June 16, 2016.

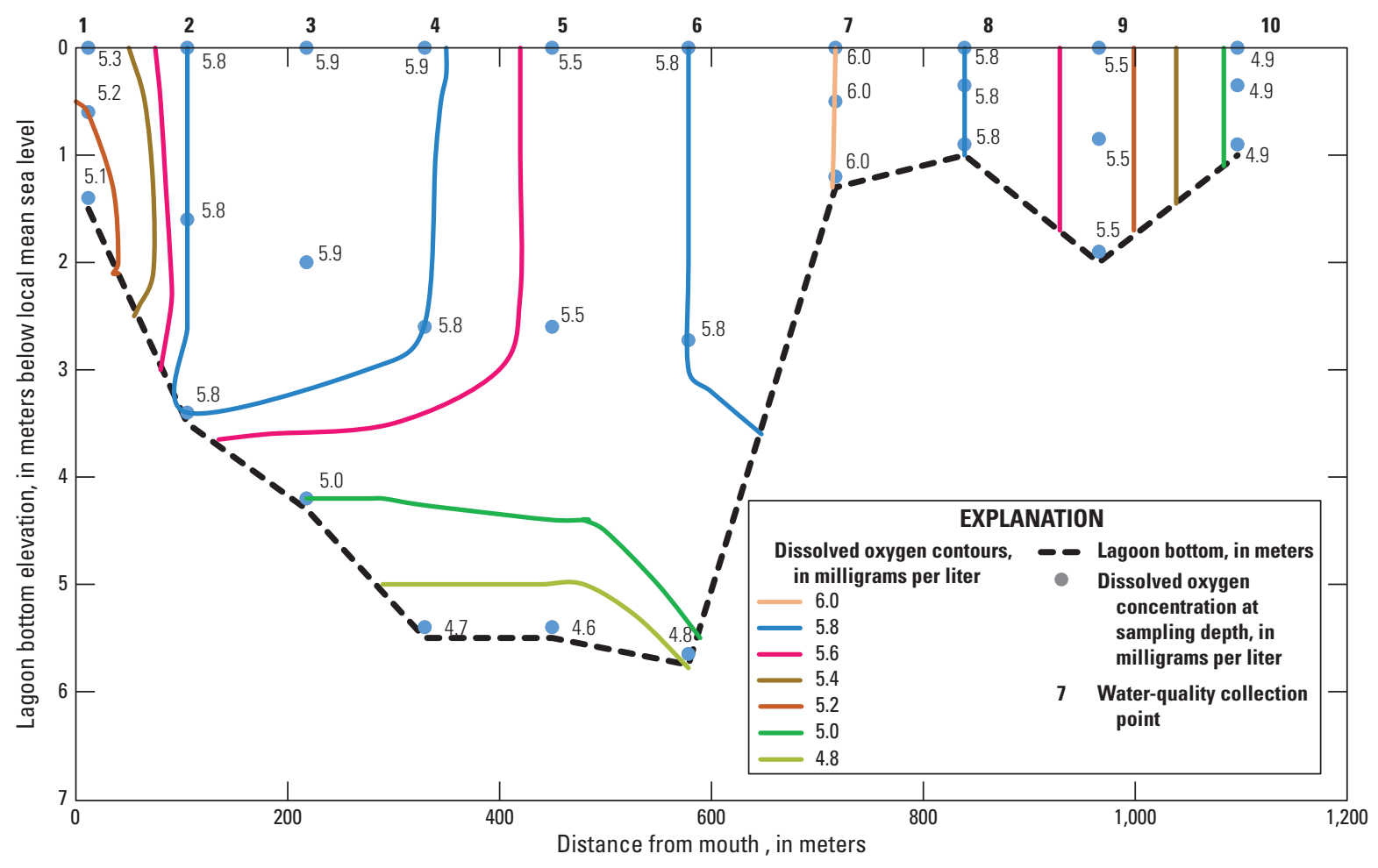

Figure 10. Dissolved oxygen concentrations at Puerto Mosquito, Isla de Vieques, Puerto Rico, June 16, 2016. 


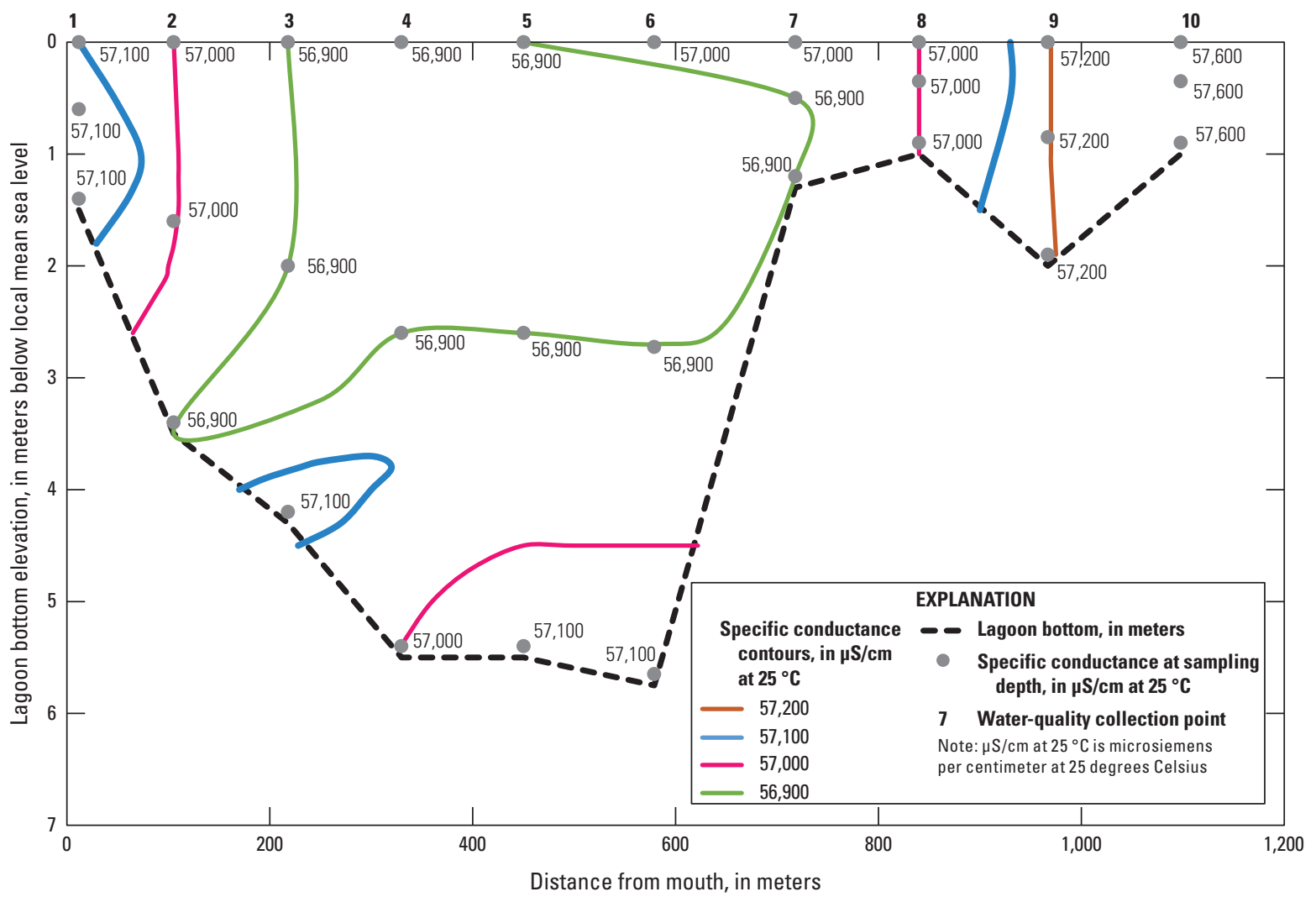

Figure 11. Specific conductance concentrations at Puerto Mosquito, Isla de Vieques, Puerto Rico, June 16, 2016.

\section{Net Phytoplankton Primary Productivity, Plankton} Respiration, and Gross Plankton Productivity

Primary productivity by phytoplankton was determined through the incubation of light and dark bottles $(0.1 \mathrm{~m}$ depth $)$ in each lagoon. A total of 12 in-situ incubations were conducted on a monthly basis with a duration of incubation ranging from 3.5 to 4.5 hours. DO concentrations were determined using the Winkler method. For each bottle incubated, 2 or 3 titrations were conducted, and an average of the DO concentration determinations is presented (tables 6-9).

Analysis of DO concentrations obtained from incubated light and dark bottles at the Caño Boquerón indicated that the average net primary productivity by phytoplankton was about 0.11 milligrams of oxygen per liter per hour $\left(\mathrm{mgO}_{2} / \mathrm{L}-\mathrm{h}\right)$. The average plankton respiration and gross plankton productivity rates were 0.11 and $0.22 \mathrm{mgO}_{2} / \mathrm{L}$-h, respectively (averaging both stations; tables 6 and 7). The stations selected for in-situ incubation were CB No. 1 and CB No. 2 (table 1; fig. 2). Results of the analysis on a daily basis were obtained by multiplying the net primary productivity and respiration rates by the duration (in hours) of presumed active productivity and respiration, respectively. The number of hours during which primary productivity occurred was determined to be about 6.69 hours per day (based on the diel studies conducted in
October 2015 and March 2016); therefore, net productivity by phytoplankton was calculated to be about 0.74 grams of oxygen per cubic meter per day $\left(\mathrm{gO}_{2} / \mathrm{m}^{3}-\mathrm{d}\right)$. This value represents about 51 percent of the total net productivity in the lagoon $\left(1.44 \mathrm{gO}_{2} / \mathrm{m}^{3}-\mathrm{d}\right)$, which was calculated through the diel studies, and is discussed later. Whereas respiration is expected to occur 24 hours a day, daily respiration was determined to be $2.64 \mathrm{gO}_{2} / \mathrm{m}^{3}-\mathrm{d}$ (obtained by multiplying $0.11 \mathrm{mg} \mathrm{O} / \mathrm{L}-\mathrm{h}$ by 24 hours); thus, average daily gross productivity of phytoplankton was calculated to be about $3.38 \mathrm{gO}_{2} / \mathrm{m}^{3}-\mathrm{d}$. Figure 12 presents a descriptive explanation of the primary productivity components using the estimates for Caño Boquerón.

The production in coastal lagoons is also described by the use of the equivalence of oxygen concentration to carbon production, which is obtained by multiplying net primary productivity in units of $\mathrm{gO}_{2} / \mathrm{m}^{3}$-d by the factor 0.375 to convert to units of grams of carbon per cubic meter per day $\left(\mathrm{gC} / \mathrm{m}^{3}-\mathrm{d}\right)$ (Mohapatra and Patra, 2012); hence, net organic carbon production for Caño Boquerón was estimated to be $0.28 \mathrm{gC} / \mathrm{m}^{3}-\mathrm{d}$. The productive volume of Caño Boquerón can be estimated using the average water transparency because this parameter represents the average depth of light penetration; assuming no light attenuation from water surface 
Table 6. Primary productivity by phytoplankton at CB No. 1 in Caño Boquerón, Cabo Rojo, Puerto Rico, July 2015-July 2016.

[All dissolved oxygen concentrations are in milligrams per liter; all productivity and respiration rates are in milligrams of oxygen per liter per hour; OI, initial dissolved oxygen concentration; OL, light bottle dissolved oxygen concentration; OD, dark bottle dissolved oxygen concentration; GP, gross production, in milligrams per liter; NP, net production, in milligrams per liter; R, respiration, in milligrams per liter; IT, incubation time, in hours; GP rate, gross productivity rate; NP rate, net productivity rate; $\mathrm{R}$ rate, respiration rate; $\mathrm{CB}$, Caño Boquerón; del, result deleted because sample was damaged]

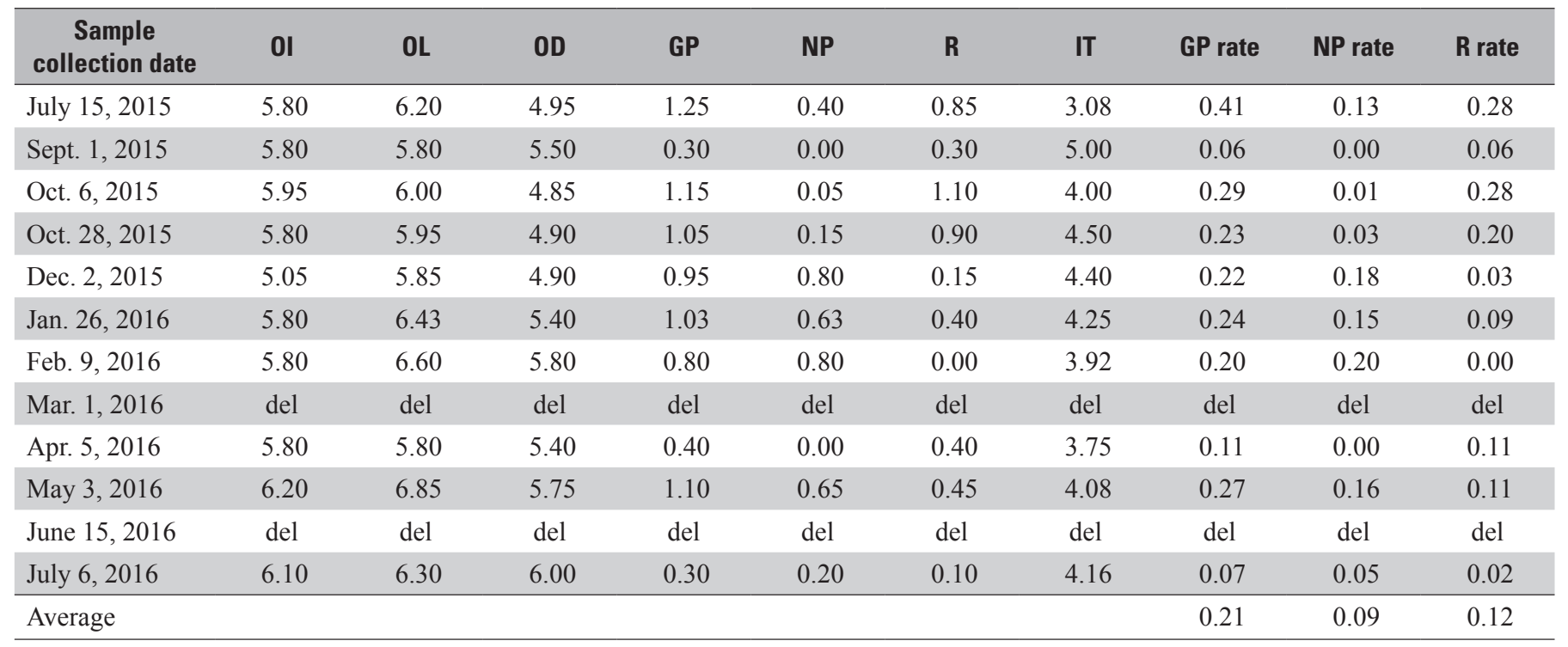

Table 7. Primary productivity by phytoplankton at CB No. 2 in Caño Boquerón, Cabo Rojo, Puerto Rico, July $2016-J u l y ~ 2017$.

[All dissolved oxygen concentrations are in milligrams per liter; all productivity and respiration rates are in milligrams of oxygen per liter per hour; OI, initial dissolved oxygen concentration; OL, light bottle dissolved oxygen concentration; OD, dark bottle dissolved oxygen concentration; are in milligrams of oxygen per liter per hour; OI, initial dissolved oxygen concentration; OL, light bottle dissolved oxygen; OD, dark bottle dissolved oxygen; GP, gross production, in milligrams per liter; NP, net production, in milligrams per liter; R, respiration, in milligrams per liter; IT, incubation time, in hours; GP rate, gross productivity rate; NP rate, net productivity rate; $\mathrm{R}$ rate, respiration rate; $\mathrm{CB}$, Caño Boquerón; del, result deleted because sample was damaged]

\begin{tabular}{lllllllllll}
\hline $\begin{array}{c}\text { Sample } \\
\text { collection date }\end{array}$ & OI & OL & OD & GP & NP & R & IT & GP rate & NP rate & R rate \\
\hline July 15, 2015 & del & del & del & del & del & del & del & del & del & del \\
\hline Sept. 1, 2015 & 5.50 & 5.60 & 4.85 & 0.75 & 0.10 & 0.65 & 4.97 & 0.15 & 0.02 & 0.13 \\
\hline Oct. 6, 2015 & 5.15 & 5.45 & 5.00 & 0.45 & 0.30 & 0.15 & 3.92 & 0.11 & 0.08 & 0.04 \\
\hline Oct. 28, 2015 & 5.80 & 6.30 & 5.70 & 0.60 & 0.50 & 0.10 & 4.43 & 0.14 & 0.11 & 0.02 \\
\hline Dec. 2, 2015 & 6.10 & 6.10 & 4.15 & 1.95 & 0.00 & 1.95 & 4.33 & 0.45 & 0.00 & 0.45 \\
\hline Jan. 26, 2015 & 4.60 & 6.10 & 4.60 & 1.50 & 1.50 & 0.00 & 4.18 & 0.36 & 0.36 & 0.00 \\
\hline Feb. 9, 2016 & 5.85 & 6.70 & 5.60 & 1.10 & 0.85 & 0.25 & 3.83 & 0.29 & 0.22 & 0.07 \\
\hline Mar. 1, 2016 & 5.95 & 6.90 & 5.90 & 1.00 & 0.95 & 0.05 & 3.92 & 0.26 & 0.24 & 0.01 \\
\hline Apr. 5, 2016 & 5.80 & 6.60 & 5.80 & 0.80 & 0.80 & 0.00 & 3.90 & 0.21 & 0.21 & 0.00 \\
\hline May 3, 2016 & 6.20 & 6.20 & 5.50 & 0.70 & 0.00 & 0.70 & 4.12 & 0.17 & 0.00 & 0.17 \\
\hline June 15, 2016 & 5.75 & 5.90 & 5.30 & 0.60 & 0.15 & 0.45 & 4.25 & 0.14 & 0.04 & 0.11 \\
\hline July 6, 2016 & 5.70 & 5.95 & 5.13 & 0.82 & 0.25 & 0.57 & 4.38 & 0.19 & 0.06 & 0.13 \\
\hline Average & & & & & & & & 0.22 & 0.12 & 0.10 \\
\hline
\end{tabular}


Table 8. Primary productivity by phytoplankton at PM No. 2 in Puerto Mosquito, Isla de Vieques, Puerto Rico, July 2015-July 2016.

[All dissolved oxygen concentrations are in milligrams per liter; all productivity and respiration rates are in milligrams of oxygen per liter per hour; OI, initial dissolved oxygen concentration; OL, light bottle dissolved oxygen concentration; OD, dark bottle dissolved oxygen concentration; GP, gross production, in milligrams per liter; NP, net production, in milligrams per liter; R, respiration, in milligrams per liter; IT, incubation time, in hours; GP rate, gross productivity rate; NP rate, net productivity rate; R rate, respiration rate; PM, Puerto Mosquito; del, result deleted because sample was damaged]

\begin{tabular}{|lccccccccccc}
\hline $\begin{array}{c}\text { Sample } \\
\text { collection date }\end{array}$ & OI & OL & OD & GP & NP & R & IT & GP rate & NP rate & R rate \\
\hline Aug. 12, 2015 & 6.40 & 7.00 & 6.10 & 0.90 & 0.60 & 0.30 & 5.00 & 0.18 & 0.12 & 0.06 \\
\hline Sept. 9, 2015 & 6.50 & 6.60 & 5.60 & 1.00 & 0.10 & 0.90 & 5.28 & 0.19 & 0.02 & 0.17 \\
\hline Oct. 14, 2015 & 6.15 & 6.35 & 6.00 & 0.35 & 0.20 & 0.15 & 4.57 & 0.08 & 0.04 & 0.03 \\
\hline Nov. 5, 2015 & 6.30 & 6.63 & 5.30 & 1.33 & 0.33 & 1.00 & 4.22 & 0.32 & 0.08 & 0.24 \\
\hline Dec. 8, 2015 & 6.20 & 6.53 & 6.10 & 0.43 & 0.33 & 0.10 & 4.50 & 0.10 & 0.07 & 0.02 \\
\hline Jan. 20, 2016 & 6.20 & 6.33 & 5.83 & 0.50 & 0.13 & 0.37 & 4.36 & 0.11 & 0.03 & 0.08 \\
\hline Feb. 2, 2016 & del & del & del & del & del & del & del & del & del & del \\
\hline Mar. 8, 2016 & 6.40 & 6.40 & 6.00 & 0.40 & 0.00 & 0.40 & 4.42 & 0.09 & 0.00 & 0.09 \\
\hline Apr. 12, 2016 & 6.45 & 6.50 & 6.10 & 0.40 & 0.05 & 0.35 & 3.95 & 0.10 & 0.01 & 0.09 \\
\hline May 10, 2016 & 7.00 & 7.10 & 6.95 & 0.15 & 0.10 & 0.05 & 4.30 & 0.03 & 0.02 & 0.01 \\
\hline June 21, 2016 & 6.00 & 6.48 & 6.00 & 0.48 & 0.48 & 0.00 & 4.12 & 0.12 & 0.12 & 0.00 \\
\hline July 12, 2016 & 6.40 & 6.43 & 6.40 & 0.03 & 0.03 & 0.00 & 4.05 & 0.01 & 0.01 & 0.00 \\
\hline Average & & & & & & & & 0.12 & 0.05 & 0.07 \\
\hline
\end{tabular}

Table 9. Primary productivity by phytoplankton at PM No. 7 in Puerto Mosquito, Isla de Vieques, Puerto Rico, July 2015-July 2016.

[All dissolved oxygen concentrations are in milligrams per liter; all productivity and respiration rates are in milligrams of oxygen per liter per hour; OI, initial dissolved oxygen concentration; OL, light bottle dissolved oxygen concentration; OD, dark bottle dissolved oxygen concentration; GP, gross production, in milligrams per liter; NP, net production, in milligrams per liter; R, respiration, in milligrams per liter; IT, incubation time, in hours; GP rate, gross productivity rate; NP rate, net productivity rate; R rate, respiration rate; PM, Puerto Mosquito; del, result deleted because sample was damaged]

\begin{tabular}{|c|c|c|c|c|c|c|c|c|c|c|}
\hline $\begin{array}{l}\text { Sample } \\
\text { collection date }\end{array}$ & 이 & $\mathrm{OL}$ & OD & GP & NP & $\mathbf{R}$ & IT & GP rate & NP rate & $\mathbf{R}$ rate \\
\hline Aug. 12, 2015 & 6.00 & 6.10 & 5.45 & 0.65 & 0.10 & 0.55 & 5.00 & 0.13 & 0.02 & 0.11 \\
\hline Oct. 14,2015 & del & del & del & del & del & del & del & del & del & del \\
\hline Nov. 5, 2015 & 5.00 & 5.25 & 4.80 & 0.45 & 0.25 & 0.20 & 4.13 & 0.11 & 0.06 & 0.05 \\
\hline Feb. 2, 2016 & del & del & del & del & del & del & del & del & del & del \\
\hline Mar. 8, 2016 & 5.60 & 5.60 & 5.40 & 0.20 & 0.00 & 0.20 & 4.6 & 0.04 & 0.00 & 0.04 \\
\hline Apr. 12, 2016 & del & del & del & del & del & del & del & del & del & del \\
\hline May 10, 2016 & del & del & del & del & del & del & del & del & del & del \\
\hline
\end{tabular}




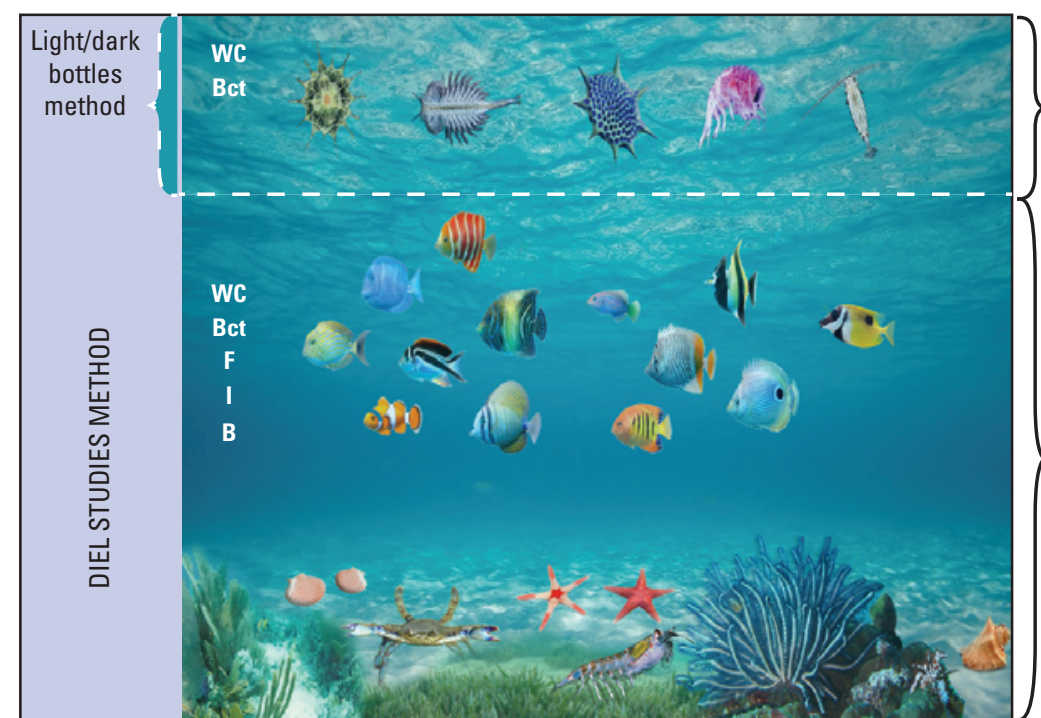

Primary productivity values, in grams of oxygen per cubic meter per day $\left(\mathrm{gO}_{2} / \mathrm{m}^{3}-\mathrm{d}\right)$

\section{EXPLANATION}

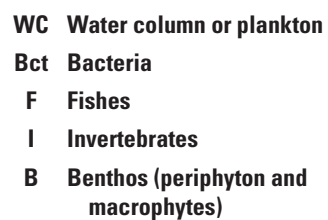

Figure 12. Primary productivity configuration using estimates for Caño Boquerón, Cabo Rojo, Puerto Rico.

to average water transparency. Through bathymetric analysis, it was estimated that the storage volume at a depth of $1.0 \mathrm{~m}$ (average water transparency) was about 535,157 $\mathrm{m}^{3}$, which represents the lagoon volume with light penetration, and thus, the productive volume. Net productivity by the phytoplankton community was therefore estimated to be about 52 tons of carbon per year (ton $\mathrm{C} / \mathrm{yr}$ ).

Net primary productivity at Puerto Mosquito was calculated at stations PM No. 2 and PM No. 7, which had similar results, and the annual average net phytoplankton primary productivity of the lagoon was estimated to be $0.05 \mathrm{mgO}_{2} / \mathrm{L}-\mathrm{h}$. Average plankton respiration rates were about $0.07 \mathrm{mgO}_{2} / \mathrm{L}-\mathrm{h}$; therefore, gross plankton productivity was about $0.12 \mathrm{mgO}_{2} / \mathrm{L}-\mathrm{h}$ (tables 8 and 9 ). Net primary productivity rates by phytoplankton were about $0.39 \mathrm{gO}_{2} / \mathrm{m}^{3}-\mathrm{d}$ and were obtained by multiplying the hourly net productivity rate by the number of hours for which productivity occurred (estimated as 7.82 hours based on diel studies). Of the net community primary productivity of Puerto Mosquito (2.43 $\left.\mathrm{gO}_{2} / \mathrm{m}^{3}-\mathrm{d}\right)$, about 16 percent corresponds to net phytoplankton productivity. Respiration occurs 24 hours per day, and therefore the daily plankton respiration rate was calculated to be about $1.68 \mathrm{gO}_{2} / \mathrm{m}^{3}-\mathrm{d}$. The gross plankton productivity (the sum of net primary productivity and respiration) was about $2.07 \mathrm{gO}_{2} / \mathrm{m}^{3}-\mathrm{d}$. Organic carbon production was estimated to be $0.15 \mathrm{gC} / \mathrm{m}^{3}-\mathrm{d}$, about half of the organic carbon net productivity in Caño Boquerón $\left(0.26 \mathrm{gC} / \mathrm{m}^{3}-\mathrm{d}\right)$. The productive volume was estimated using the average water transparency $(1.87 \mathrm{~m})$ measured throughout the lagoon. Based on this productive volume $\left(911,871 \mathrm{~m}^{3}\right)$, total organic net production by phytoplankton was estimated as 49 tons $\mathrm{C} / \mathrm{yr}$.

\section{Net Community Primary Productivity, Respiration, and Gross Productivity}

In addition to phytoplankton primary productivity in Caño Boquerón and Puerto Mosquito, other organisms also contribute to the oxygen production in these aquatic ecosystems. Two diel studies were conducted on each lagoon (tables 10 and 11) to assess the oxygen diurnal cycle and ultimately to determine community primary productivity. Field parameters were also recorded during the diel studies. All measures of DO concentration were corrected for water column diffusion to/from atmosphere (Caffrey and others, 2014), and a detailed explanation of the primary productivity calculations is provided in Gomez-Fragoso and Santiago-Sáez (2018).

Diel studies at Caño Boquerón were conducted on October 29, 2015, and March 2, 2016. Diurnal variations in DO concentrations were evident at CB No. 4 during the diel study conducted on October 29, 2015 (fig. 13). An increase during daytime hours was observed as photosynthetic processes dominated, resulting in peak DO concentrations from 1230 to 1630 hours; DO concentrations decreased in the latter part of the day as sunlight decreased and respiration dominated the metabolic processes in the lagoon. For the 
Table 10. Results of diel study of community primary productivity at Caño Boquerón, Cabo Rojo, Puerto Rico.

[Station number is U.S. Geological Survey station identification number; All values are in grams of oxygen per cubic meter per day; CB, Caño Boquerón]

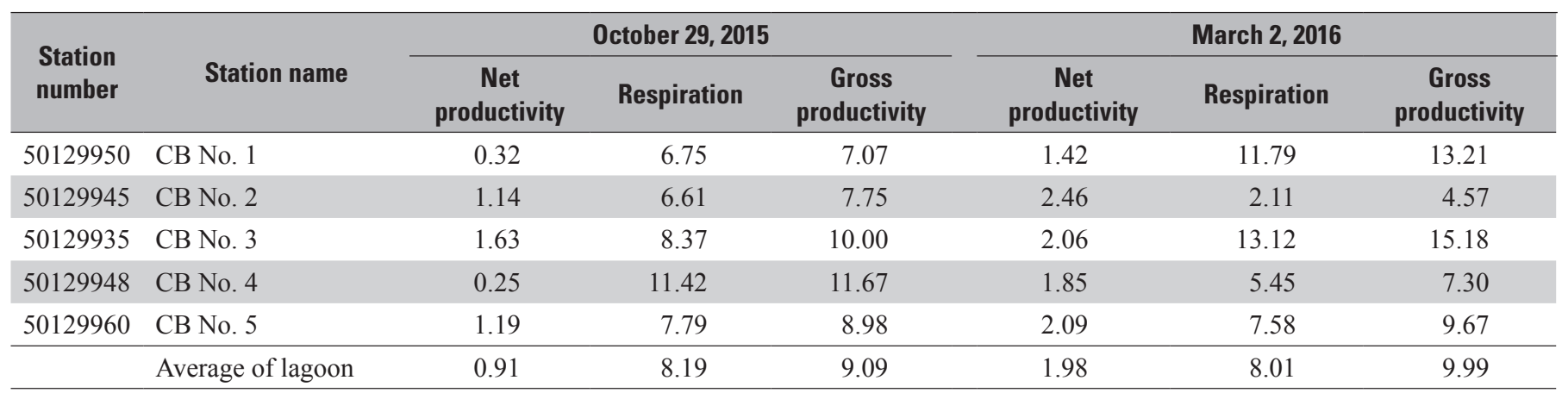

Table 11. Results of diel study of community primary productivity at Puerto Mosquito, Isla de Vieques, Puerto Rico.

[Station number is U.S. Geological Survey station identification number. All values are in grams of oxygen per cubic meter per day]

\begin{tabular}{|c|c|c|c|c|c|c|c|}
\hline \multirow{2}{*}{$\begin{array}{l}\text { Station } \\
\text { number }\end{array}$} & \multirow[b]{2}{*}{ Station name } & \multicolumn{3}{|c|}{ November 17, 2015} & \multicolumn{3}{|c|}{ March 9, 2016} \\
\hline & & $\begin{array}{c}\text { Net } \\
\text { productivity }\end{array}$ & Respiration & $\begin{array}{c}\text { Gross } \\
\text { productivity }\end{array}$ & $\begin{array}{c}\text { Net } \\
\text { productivity }\end{array}$ & Respiration & $\begin{array}{c}\text { Gross } \\
\text { productivity }\end{array}$ \\
\hline 50231507 & $\begin{array}{l}\text { Laguna Bahía Mos- } \\
\text { quito No. } 4\end{array}$ & 2.31 & 4.74 & 7.05 & 1.74 & 6.60 & 8.34 \\
\hline 50231520 & $\begin{array}{l}\text { Laguna Bahía Mos- } \\
\text { quito No. } 6\end{array}$ & 5.15 & 10.77 & 15.92 & 1.23 & 4.10 & 5.33 \\
\hline 50231502 & $\begin{array}{l}\text { Laguna Bahía Mos- } \\
\text { quito No. } 7\end{array}$ & 2.95 & 5.27 & 8.22 & 4.1 & 8.87 & 12.97 \\
\hline
\end{tabular}

diel study on October 29, 2015, the average net community productivity and respiration rates were $0.91 \mathrm{gO}_{2} / \mathrm{m}^{3}-\mathrm{d}$ (66 tons $\mathrm{C} / \mathrm{yr}$ ) and $8.19 \mathrm{gO}_{2} / \mathrm{m}^{3}$-d, respectively; therefore, gross productivity was about $9.10 \mathrm{gO}_{2} / \mathrm{m}^{3}-\mathrm{d}$. For the diel study conducted on March 2, 2016, the average net community primary productivity was $1.98 \mathrm{gO}_{2} / \mathrm{m}^{3}-\mathrm{d}$ (145 tons $\mathrm{C} / \mathrm{yr}$ ), and the respiration rate was about $8.01 \mathrm{gO}_{2} / \mathrm{m}^{3}-\mathrm{d}$. Gross productivity was $9.99 \mathrm{gO}_{2} / \mathrm{m}^{3}-\mathrm{d}$. Average net community primary productivity at Caño Boquerón was $1.44 \mathrm{gO}_{2} / \mathrm{m}^{3}-\mathrm{d}$ (106 tons $\mathrm{C} / \mathrm{yr}$ ). Respiration rates averaged $8.10 \mathrm{gO}_{2} / \mathrm{m}^{3}-\mathrm{d}$, and the average gross productivity was $9.54 \mathrm{gO}_{2} / \mathrm{m}^{3}-\mathrm{d}$ (table 12 ). Higher values for community primary productivity were generally observed in the diel study conducted during March 2016 than in the October 2015 study. Several factors can explain the difference between the net community primary productivity computations in October 2015, and March 2016, including variations in nutrient loading, incident solar radiation and temperature, among others. The highest concentration of total nitrogen (table 4) measured at Puerto Mosquito occurred on March 1, 2015, a day prior to the diel study.
Community primary productivity for Puerto Mosquito was calculated during the diel studies conducted on November 17, 2015, and March 9, 2016. Magnitude in DO concentrations reached peak values between 14:00 and 16:00 (fig. 14). During November 17, 2015, the average net community productivity was about $2.70 \mathrm{gO}_{2} / \mathrm{m}^{3}-\mathrm{d}$ (334 tons $\mathrm{C} / \mathrm{yr}$ ) and the respiration rate was $7.76 \mathrm{gO}_{2} / \mathrm{m}^{3}-\mathrm{d}$; therefore, community gross productivity was calculated to be about $10.46 \mathrm{gO}_{2} / \mathrm{m}^{3}-\mathrm{d}$. Higher net community primary productivity estimates were observed at PM No. 6 and PM No. 7 (table 11), which are located along the shallower areas in the northern and western parts of the lagoon (fig. 3). Results of the diel study conducted on March 9, 2016, indicate that the average gross community productivity was $7.83 \mathrm{gO}_{2} / \mathrm{m}^{3}-\mathrm{d}$, of which $2.16 \mathrm{gO}_{2} / \mathrm{m}^{3}-\mathrm{d}$ (269 tons $\mathrm{C} / \mathrm{yr}$ ) accounts for net community productivity and $5.68 \mathrm{gO}_{2} / \mathrm{m}^{3}-\mathrm{d}$ is the respiration rate. Compositing both diel studies for Puerto Mosquito, the average net community primary productivity was $2.43 \mathrm{gO}_{2} / \mathrm{m}^{3}-\mathrm{d}$ (303 tons $\mathrm{C} / \mathrm{yr}$ ), and the community respiration rate was $6.72 \mathrm{gO}_{2} / \mathrm{m}^{3}$-d (table 12). Average gross community productivity was $9.15 \mathrm{gO}_{2} / \mathrm{m}^{3}$-d. 


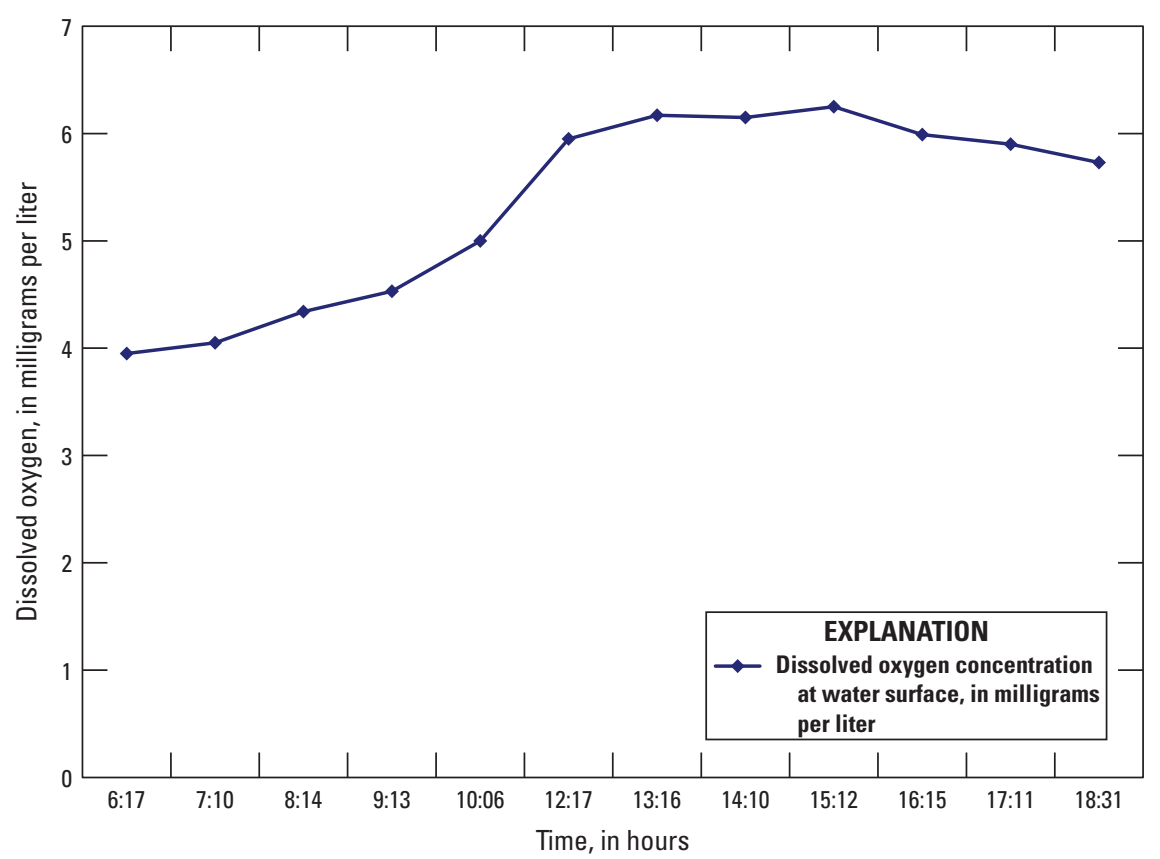

Figure 13. Diurnal variation in dissolved oxygen concentrations during diel study at CB. No. 4, Caño Boquerón, Cabo Rojo, Puerto Rico, October 29, 2015.

Table 12. Summary of primary productivity results at Caño Boquerón, Cabo Rojo, and Puerto Mosquito, Isla de Vieques, Puerto Rico, July 2015-July 2016.

[All values are in grams of oxygen per cubic meter per day]

\begin{tabular}{|c|c|c|c|c|c|c|c|c|c|}
\hline \multirow[b]{2}{*}{ Site } & \multicolumn{3}{|c|}{ Community } & \multicolumn{3}{|c|}{ Phytoplankton } & \multicolumn{3}{|c|}{ Benthos } \\
\hline & $\begin{array}{c}\text { Net produc- } \\
\text { tivity }\end{array}$ & Respiration & $\begin{array}{c}\text { Gross pro- } \\
\text { ductivity }\end{array}$ & $\begin{array}{c}\text { Net produc- } \\
\text { tivity }\end{array}$ & Respiration & $\begin{array}{l}\text { Gross pro- } \\
\text { ductivity }\end{array}$ & $\begin{array}{l}\text { Net produc- } \\
\text { tivity }\end{array}$ & Respiration & $\begin{array}{c}\text { Gross pro- } \\
\text { ductivity }\end{array}$ \\
\hline $\begin{array}{l}\text { Puerto Mosquito, } \\
\text { Isla de Vieques }\end{array}$ & 2.43 & 6.72 & 9.15 & 0.39 & 1.68 & 2.07 & 2.04 & 5.04 & 7.08 \\
\hline
\end{tabular}

As mentioned earlier, gross community productivity includes all organisms (plankton, periphyton, macrophytes, and so forth) and gross phytoplankton productivity accounts for plankton organisms (phytoplankton and zooplankton) in the water column. Table 12 summarizes the results of the light and dark bottle analysis and diel studies for Caño Boquerón and Puerto Mosquito. Of the estimated average net community productivity for Caño Boquerón $\left(1.44 \mathrm{gO}_{2} / \mathrm{m}^{3}-\mathrm{d}\right)$, about $0.74 \mathrm{gO}_{2} / \mathrm{m}^{3}-\mathrm{d}$ was ascribed to phytoplankton; thus, an estimated $0.71 \mathrm{gO}_{2} / \mathrm{m}^{3}$-d was produced by benthic organisms, including periphyton and macrophytes (fig. 12). This contribution from benthic organisms represents about 51 percent of the net community productivity. For Puerto Mosquito, about 16 percent $\left(0.39 \mathrm{gO}_{2} / \mathrm{m}^{3}-\mathrm{d}\right)$ of the net community primary productivity $\left(2.43 \mathrm{gO}_{2} / \mathrm{m}^{3}\right.$-d) was produced by phytoplankton; thus, the net primary productivity by benthos (periphyton and macrophytes) was about $2.04 \mathrm{gO}_{2} / \mathrm{m}^{3}$-d (table 12).
The results of community primary productivity computations for both lagoons indicated that the primary productivity by phytoplankton (water column) is greater in Caño Boquerón compared to Puerto Mosquito. As noted earlier, about 16 percent of the community primary productivity at Puerto Mosquito can be ascribed to phytoplankton organisms, which reside in the water column. In contrast, for Caño Boquerón, the phytoplankton primary productivity (water column) accounted for about 51 percent of the community primary productivity. As mentioned previously, several variables may have an effect on the community primary productivity, such as incident solar radiation, wind, nutrient loading and turbidity, water levels, and bottom characteristics; therefore, a combination of factors may contribute to the percentage of community primary productivity ascribed to phytoplankton. A possible explanation may be the occurrence of less seagrass in the bottom of Caño Boquerón compared to the bottom of 


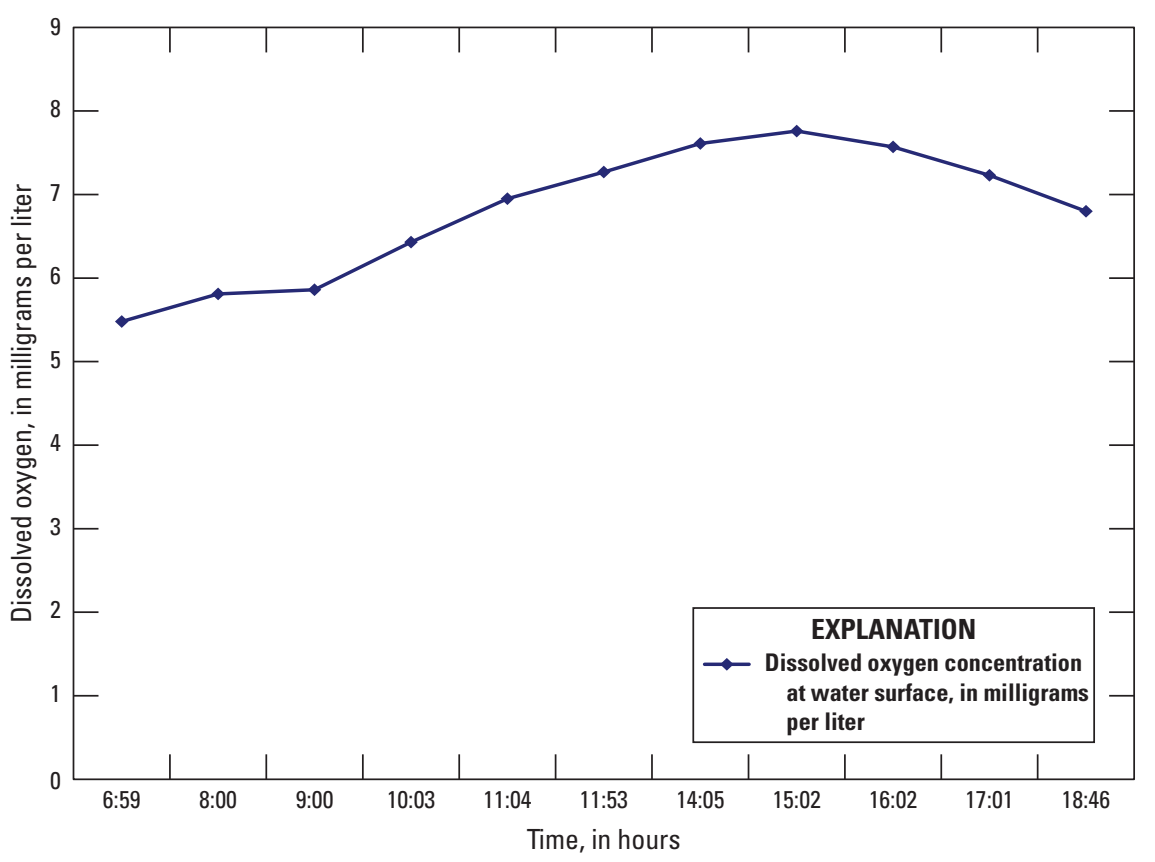

Figure 14. Diurnal variation in dissolved oxygen concentrations during diel study at PM No. 7, Puerto Mosquito, Isla de Vieques, Puerto Rico, March 9, 2016.

Puerto Mosquito, which may lead to a lower contribution of benthic organism to the community primary productivity. Compared to Caño Boquerón, more seagrass was observed in the bottom of Puerto Mosquito, which coincided with a higher percentage of the community primary productivity attributable to benthic organisms. Diel study results also indicated that the community primary productivity for Puerto Mosquito was greater on November 17, 2016, whereas Caño Boquerón showed a greater community primary productivity on March 2, 2016. Each diel study represents a snapshot of the DO concentration diurnal pattern, and there is likely no single factor controlling the primary production. Although correlations were found between total nitrogen concentrations and the computed average net community primary productivity at Caño Boquerón, no comparative analysis was made for Puerto Mosquito because water-quality sampling was not conducted in Puerto Mosquito during the diel study on November 17, 2015. Further analysis would be needed to assess seasonal variability and correlations with other factors affecting the primary production.

\section{Other Productivity Indic ators}

Algal biomass in lagoons was evaluated by collecting water samples for the analysis of phytoplankton biomass and chlorophyll $a$ concentrations. These analyses determined the weight of the photosynthetic organisms, along with the principal photosynthetic pigment, which provide an indication of primary production. In addition, phytoplankton biomass serves to assess nutrient levels, and thus, trophic status of inland waters.

\section{Phytoplankton Biomass}

The results of the phytoplankton biomass analysis of water samples collected at Caño Boquerón and Puerto Mosquito are presented in table 13. The average phytoplankton biomass at CB No. 1 and CB No. 2 was 10.0 and $12.3 \mathrm{mg} / \mathrm{L}$, respectively. Phytoplankton biomass in Caño Boquerón averaged $11.1 \mathrm{mg} / \mathrm{L}$ and ranged from 7.4 to $21.5 \mathrm{mg} / \mathrm{L}$. The highest phytoplankton biomass occurred in CB No. 2 on December 2, 2016, which coincided with a rainfall event that occurred the 3 days before the sample was collected (fig. 6). Comparison of the net community primary productivity for Caño Boquerón (CB No. 1 and CB No. 2) and the biomass concentration at CB No. 1 and CB No. 2 (collected the day prior to each diel study) indicated a direct relation between primary productivity and biomass (fig. 15; tables 10 and 13).

Analyses of samples collected at Puerto Mosquito indicated an average phytoplankton biomass of $11.8 \mathrm{mg} / \mathrm{L}$. Average phytoplankton biomass for PM No. 2 and PM No. 7 was 10.7 and $12.9 \mathrm{mg} / \mathrm{L}$, respectively. The phytoplankton biomass measured at Puerto Mosquito (both in PM No. 7) ranged from below detection limit (less than $6 \mathrm{mg} / \mathrm{L}$ ) on April 12, 2016, to $41.0 \mathrm{mg} / \mathrm{L}$ on March 8, 2016.

Phytoplankton biomass is widely used to provide baseline information about aquatic ecosystem production, although PREQB has no standards established for this environmental parameter at this time. A general index to estimate the turnover rate (amount that is replaced per unit time) of planktonic organisms is the ratio of gross productivity to biomass $(\mathrm{P} / \mathrm{B})$. Based on results for Caño Boquerón, average plankton daily gross productivity was $3.38 \mathrm{gO}_{2} / \mathrm{m}^{3}-\mathrm{d}\left(1,234 \mathrm{gO}_{2} / \mathrm{m}^{3}\right.$-yr $)$ 
Table 13. Phytoplankton biomass concentrations from samples collected at selected sites at Caño Boquerón, Cabo Rojo, and Puerto Mosquito, Isla de Vieques, Puerto Rico.

[Concentration of biomass in milligram per liter; CB, Caño Boquerón; number in parentheses is the U.S. Geological Survey station identification number; PM, Puerto Mosquito; <, less than; del, result deleted because sample was damaged]

\begin{tabular}{|c|c|c|c|c|c|c|}
\hline $\begin{array}{l}\text { Sampling } \\
\text { number }\end{array}$ & Date & $\begin{array}{c}\text { CB No. } 1 \\
(50129950)\end{array}$ & $\begin{array}{c}\text { CB No. } 2 \\
\text { (50129945) }\end{array}$ & Date & $\begin{array}{c}\text { PM No. } 2 \\
\text { (50231510) }\end{array}$ & $\begin{array}{c}\text { PM No. } 7 \\
\text { (50231502) }\end{array}$ \\
\hline 1 & July 15,2015 & 12.4 & 11.6 & Aug. 12, 2015 & 10.0 & 21.0 \\
\hline 3 & Oct. 6, 2015 & 8.1 & 11.3 & Oct. 14, 2015 & 8.8 & 7.4 \\
\hline 4 & Oct. 28,2015 & 8.0 & 7.8 & Nov. 5, 2015 & 9.8 & 9.4 \\
\hline 7 & Feb. 9, 2016 & 7.4 & 10.2 & Feb. 2, 2016 & 8.4 & 8.4 \\
\hline 8 & Mar. 1, 2016 & 11.3 & 15.0 & Mar. 8, 2016 & 19.2 & 41.0 \\
\hline 9 & Apr. 5, 2016 & 8.4 & 8.6 & Apr. 12, 2016 & 9.2 & $<6.0$ \\
\hline 10 & May 3, 2016 & 11.8 & 14.3 & May 10, 2016 & 8.6 & 9.8 \\
\hline
\end{tabular}

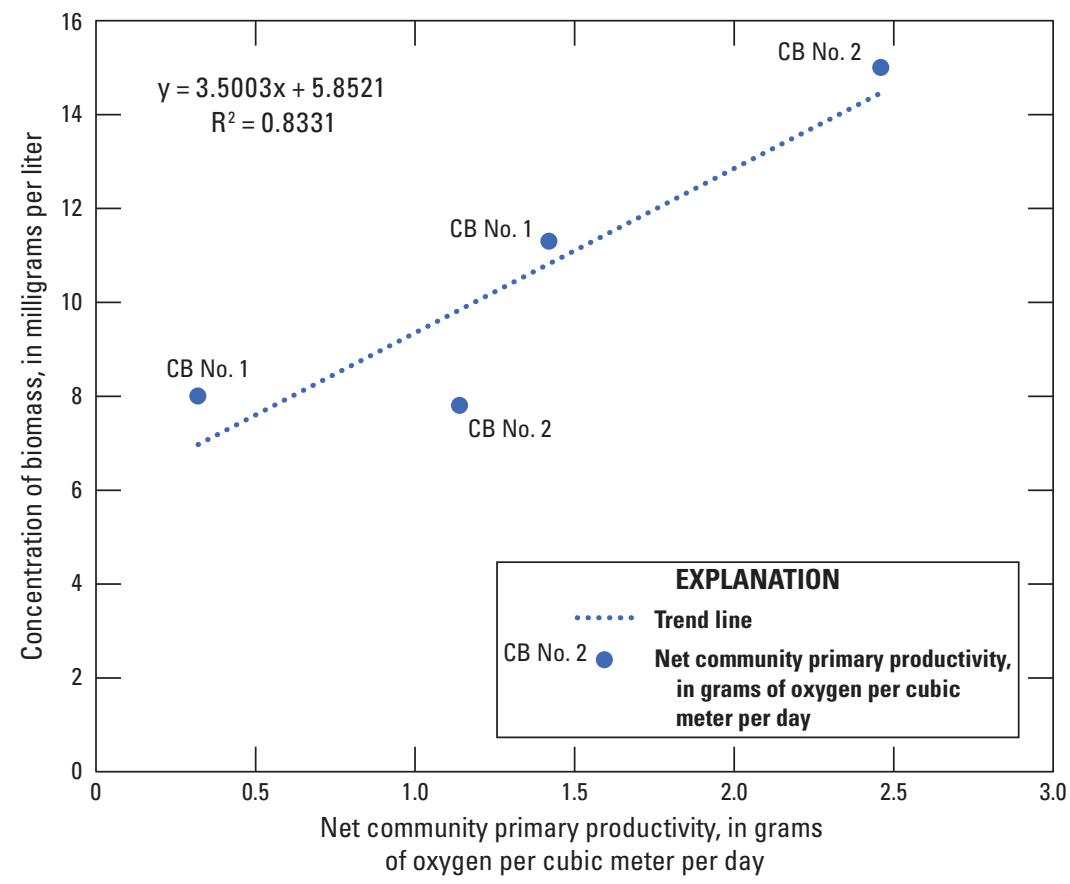

Figure 15. Relation between biomass and net community primary productivity measured in diel studies at CB No. 1 and CB No. 2, Caño Boquerón, Cabo Rojo, Puerto Rico, November 2015 and March 2016. 
and phytoplankton biomass was $11.1 \mathrm{mg} / \mathrm{L}$ (equivalent to $\left.11.1 \mathrm{~g} / \mathrm{m}^{3}\right)$; therefore, the $\mathrm{P} / \mathrm{B}$ ratio $(1,234 / 11.1)$ was about 111 . This ratio indicates that Caño Boquerón has a turnover rate of 111 times per year (approximately once every 3.3 days). For Puerto Mosquito, the average gross productivity was $2.07 \mathrm{gO}_{2} / \mathrm{m}^{3}-\mathrm{d}\left(755 \mathrm{gO}_{2} / \mathrm{m}^{3}\right.$-yr $)$, and the average phytoplankton biomass was $11.8 \mathrm{~g} / \mathrm{m}^{3}$; therefore, the $\mathrm{P} / \mathrm{B}$ ratio $(755 / 11.8)$ was about 64 . The turnover rate of 64 times per year is approximately once every 5.7 days, which is substantially longer than at Caño Boquerón.

\section{Chlorophyll a}

Chlorophyll $a$ concentration at Caño Boquerón averaged about 5.8 micrograms per liter $(\mu \mathrm{g} / \mathrm{L})$ and ranged from 2.1 to $28.8 \mu \mathrm{g} / \mathrm{L}$ for CB No. 1 and CB No. 2 (table 14). The highest concentration of chlorophyll $a$ was measured on December 2, 2016. The average chlorophyll $a$ concentrations at CB No. 1 and CB No. 2 were 4.1 and $7.7 \mathrm{mg} / \mathrm{L}$, respectively.

At Puerto Mosquito, the average chlorophyll $a$ concentrations at PM No. 2 and PM No. 7 were 2.7, and $2.5 \mathrm{mg} / \mathrm{L}$, respectively. The chlorophyll $a$ concentrations at Puerto Mosquito averaged $2.6 \mathrm{mg} / \mathrm{L}$, which is substantially lower than at Caño Boquerón. Concentrations of chlorophyll $a$ ranged from 0.2 to $7.7 \mathrm{mg} / \mathrm{L}$. The highest chlorophyll $a$ concentration was measured on September 9, 2015. There are no standards for chlorophyll $a$ concentration established by PREQB.

\section{Bacteria Indicator Analyses}

Fecal coliform and enterococci are microbial indicators that are widely used in water-quality assessments to determine fecal pollution (Dorsey and others, 2013). Sources including runoff, feces from birds, and inadequate sewage systems can contribute to contamination of water bodies. Maximum limits have been established by Federal and State agencies to avoid the impairment of beaches, lakes, and other recreational areas. In Puerto Rico, PREQB established a maximum limit of 200 and 35 colonies per 100 milliliters $(\mathrm{col} / 100 \mathrm{~mL})$ for fecal coliform and enterococci, respectively, for Class SB coastal waters. As described by Soler-López and Santos (2010), the presence of these organisms indicates their recent arrival because these organisms do not survive for prolonged periods outside of a host. Water samples were collected monthly in both lagoons and analyzed for the presence of fecal coliform and enterococci (table 15).

At Caño Boquerón, fecal coliform concentrations ranged from no detections to as much as $22 \mathrm{col} / 100 \mathrm{~mL}$ (table 15), which is below PREQB standards. The highest fecal coliform concentration occurred in July, which coincided with the busiest season of vacation rentals near the lagoon. Enterococci bacteria concentrations ranged between 1 and $9 \mathrm{col} / 100 \mathrm{~mL}$ during the sampling period. The highest concentration of enterococci bacteria in Caño Boquerón occurred on July 15, 2015. Bacteria concentrations were higher at CB No. 1 than at CB No. 2. Potential sources of bacterial contamination at Caño Boquerón include: (1) runoff from the drainage area discharging into the lagoon, (2) overflow of the sewer system originating from rental properties near the lagoon, (3) ocean currents through the inlet-outlet channel during high tides, and (4) runoff conveyed through the Lajas irrigation system discharging into a swamp area located in the northeastern part of the lagoon.

Bacteria concentrations were generally lower in Puerto Mosquito than in Caño Boquerón; maximum concentrations

Table 14. Chlorophyll a concentrations from samples collected at selected sites at Caño Boquerón, Cabo Rojo, and Puerto Mosquito, Isla de Vieques, Puerto Rico, July 2015-July 2016.

[Concentration of chlorophyll $a$ in microgram per liter; CB, Caño Boquerón; number in parentheses is the U.S. Geological Survey station identification number; PM, Puerto Mosquito; del, result deleted because sample was damaged]

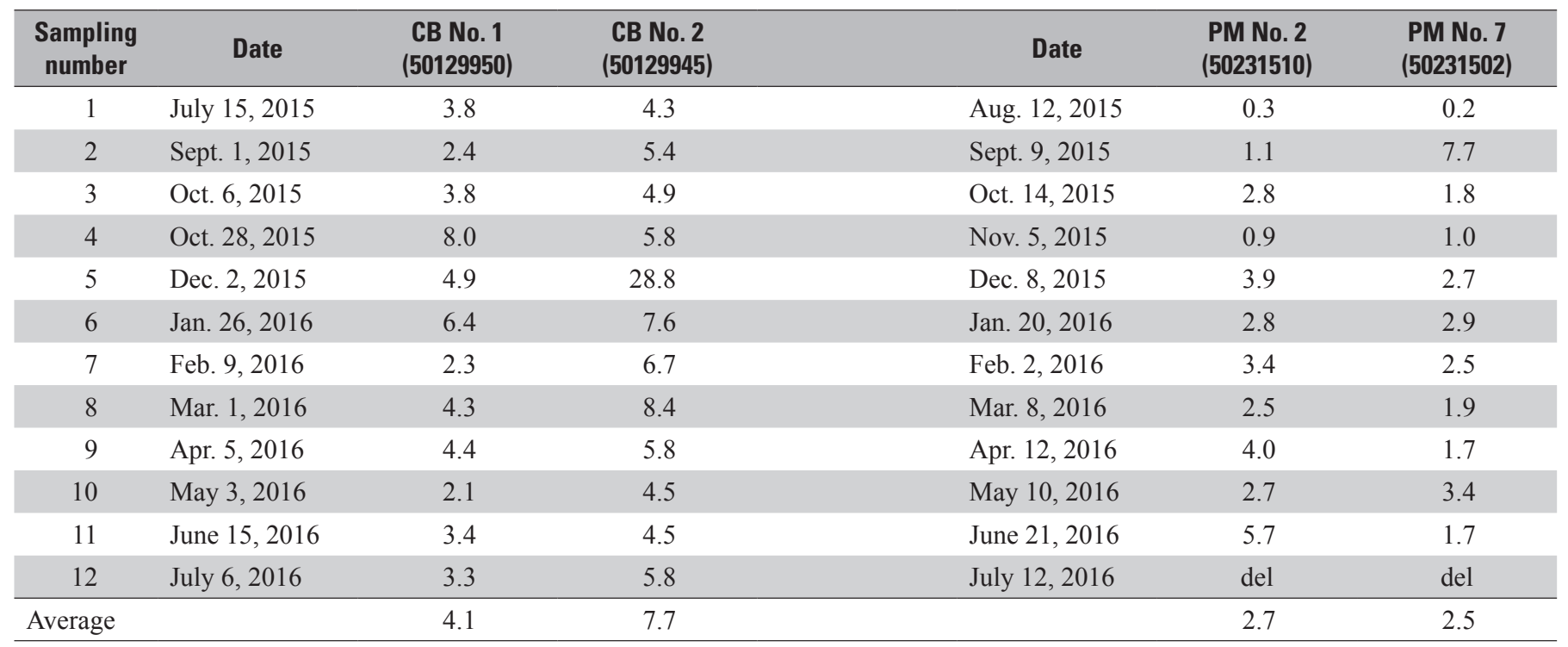


Table 15. Fecal coliform and enterococci concentrations from samples collected at selected sites at Caño Boquerón, Cabo Rojo, and Puerto Mosquito, Isla de Vieques, Puerto Rico, July 2015-July 2016.

[Values are in colonies per 100 milliliters of water; CB, Caño Boquerón; number in parentheses is the U.S. Geological Survey station identification number; PM, Puerto Mosquito; E, having a higher degree of uncertainty; <, nondetection]

\begin{tabular}{|c|c|c|c|c|c|c|c|c|c|c|}
\hline \multirow{2}{*}{$\begin{array}{c}\text { Sampling } \\
\text { number }\end{array}$} & \multirow[b]{2}{*}{ Date } & \multicolumn{2}{|c|}{ Fecal coliform } & \multicolumn{2}{|c|}{ Enterococci } & \multirow[b]{2}{*}{ Date } & \multicolumn{2}{|c|}{ Fecal coliform } & \multicolumn{2}{|c|}{ Enterococci } \\
\hline & & $\begin{array}{c}\text { CB No. } 1 \\
\text { (50129950) }\end{array}$ & $\begin{array}{c}\text { CB No. } 2 \\
\text { (50129945) }\end{array}$ & $\begin{array}{c}\text { CB No. } 1 \\
\text { (50129950) }\end{array}$ & $\begin{array}{c}\text { CB No. } 2 \\
\text { (50129945) }\end{array}$ & & $\begin{array}{c}\text { PM No. } 2 \\
(50231510)\end{array}$ & $\begin{array}{c}\text { PM No. } 7 \\
\text { (50231502) }\end{array}$ & $\begin{array}{c}\text { PM No. } 2 \\
(50231510)\end{array}$ & $\begin{array}{l}\text { PM No. } 7 \\
(50231502)\end{array}$ \\
\hline 2 & Sept. 1, 2015 & E2 & $\mathrm{E} 2$ & E2 & E1 & Sept. 9, 2015 & $<1$ & $<1$ & 1 & $<1$ \\
\hline 3 & Oct. 6, 2015 & E3 & E2 & E6 & E3 & Oct. 14, 2015 & 1 & 1 & 1 & 3 \\
\hline 6 & Jan. 26, 2016 & E2 & E2 & $<1$ & $<1$ & Jan. 20, 2016 & 1 & $<1$ & $<1$ & 2 \\
\hline 7 & Feb. 9, 2016 & E1 & E1 & E1 & E1 & Feb. 2, 2016 & $<1$ & $<1$ & $<1$ & $<1$ \\
\hline 8 & Mar. 1, 2016 & E2 & E1 & E2 & $<1$ & Mar. 8, 2016 & 1 & $<1$ & 2 & $<1$ \\
\hline 9 & Apr. 5, 2016 & E1 & E5 & E2 & E2 & Apr. 12, 2016 & $<1$ & $<1$ & $<1$ & $<1$ \\
\hline
\end{tabular}

of fecal coliform and enterococci bacteria were 3 and $5 \mathrm{col} / 100 \mathrm{~mL}$, respectively, during the November 2015 sampling event. Several bacteria analyses resulted in nondetections during the sampling period in Puerto Mosquito. The potential sources of contamination are limited because Puerto Mosquito is within a conservation area; the primary sources are runoff from drainage areas discharging into the lagoon and ocean currents entering through the inlet-outlet channel during high tides.

\section{Seawater Exchange}

Vertical fluctuations in water levels at Caño Boquerón were recorded at CB No. 3 (USGS gaging station 50129935) during July 18 , 2015-July 18, 2016. The mean maximum and minimum water levels per tidal cycle were 0.34 and $0.08 \mathrm{~m}$ above mean sea level, respectively, indicating that the average change in water level at Caño Boquerón was about $0.26 \mathrm{~m}$ per tidal cycle for the period of record. The average daily change in water level per tidal cycle $(0.31 \mathrm{~m})$ was determined by dividing the average change in water level $(0.26 \mathrm{~m})$ by the average number of tides per day (1.19 tides); the latter was computed using the average in difference in time between each tide (time interval of each maximum water level per day). The storage volume of Caño Boquerón relative to mean sea level was $967,000 \mathrm{~m}^{3}$, and the storage volume associated with the average daily change in water level per tidal cycle $(0.31 \mathrm{~m})$ was about $843,619 \mathrm{~m}^{3}$. Therefore, it is estimated that a volume of $123,381 \mathrm{~m}^{3}$ is exchanged daily between the lagoon and the ocean, representing about 13 percent of the total storage volume of Caño Boquerón.

For Puerto Mosquito, mean daily maximum and minimum water levels per tidal cycle were 0.31 and $0.13 \mathrm{~m}$, respectively, at USGS gaging station 50231500 (PM No. 1) from July 31, 2015 to July 31, 2016. The difference between the average maximum and minimum water levels indicated that the average change in water levels was $0.19 \mathrm{~m}$ per each tidal cycle. The average number of tides per day was 1.16 ; thus, the average daily change in water level per tidal cycle per day was $0.22 \mathrm{~m}$. The estimated storage volume associated with the average daily change in water level per tidal cycle was $1,118,464 \mathrm{~m}^{3}$; hence, about 5 percent of the total storage volume in Puerto Mosquito is exchanged daily between lagoon and ocean. The seawater exchange at Caño Boquerón is almost 3 times greater than in Puerto Mosquito.

\section{Sediment Accretion}

Several factors can cause coastal lagoons to lose depth and water volume: sediments transported via runoff within the drainage basin; deposits from marine coastal currents; and to a lesser degree, atmospheric deposition (Soler-López and Santos, 2010). Sediment deposition rates were estimated by collecting sediment samples from the bottom of Caño Boquerón and Puerto Mosquito and analyzing them for the presence of the radioisotopes cesium-137 $\left({ }^{137} \mathrm{Cs}\right)$ and lead-210 $\left({ }^{210} \mathrm{~Pb}\right)$.

In the sediment core samples collected from Caño Boquerón at $\mathrm{CB}$ No. $2,{ }^{137} \mathrm{Cs}$ was first found at $20 \mathrm{~cm}$ below the bottom surface of the lagoon, and year 1954 was assigned to that layer. The sediment accretion rate was estimated by dividing $20 \mathrm{~cm}$ by 61 years (the difference between 2015 and 1954), which results in an accretion rate of approximately $0.32 \mathrm{~cm} / \mathrm{yr}$. Applying the ${ }^{210} \mathrm{~Pb}$ method, the sediment accretion rate for Caño Boquerón was calculated by using the ${ }^{210} \mathrm{~Pb}$ concentration from the top part of the core $\left(3.29 \times 10^{-5}\right.$ millibequerel per gram $\left.[\mathrm{mBq} / \mathrm{g}]\right)$, and then locating 
an older (deeper) layer that has approximately half of the value that was measured at the top. The results indicated that the 8 -cm depth had the closest half-life value $\left(1.62 \times 10^{-5} \mathrm{mBq} / \mathrm{g}\right)$. Given that ${ }^{210} \mathrm{~Pb}$ radioactivity decreases by a factor of 2 every 22.3 years, the 8 -cm layer corresponds to 1993 (difference between the year of sediment core collection (2015) and half-life (22.3 years) of the radioisotope). Finally, $8 \mathrm{~cm}$ of sediment accumulation was divided by 22.3 years, resulting in an approximate sediment accretion rate of $0.36 \mathrm{~cm} / \mathrm{yr}$. The sediment accretion rates for Caño Boquerón calculated using the two isotopes are similar (fig. 16).

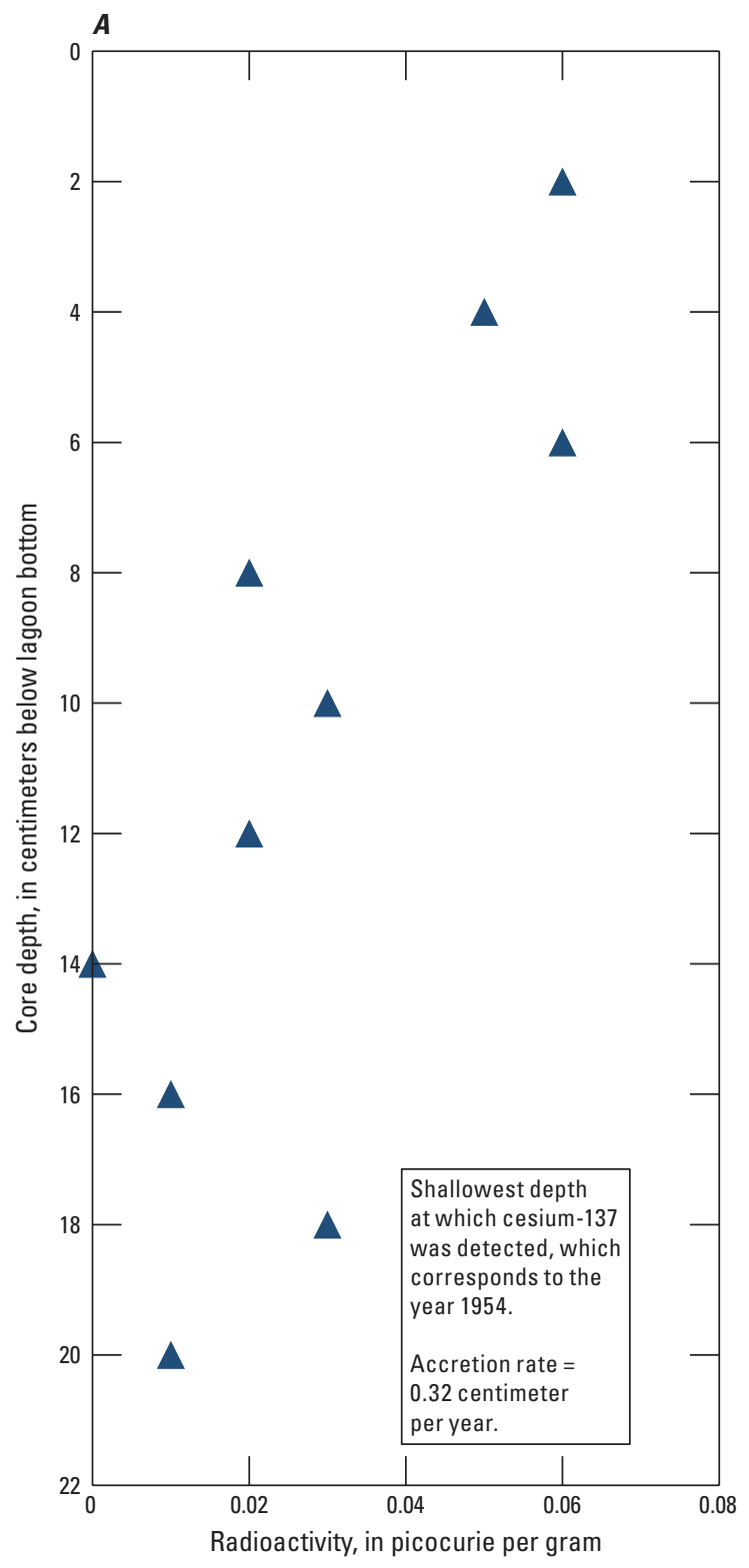

At Puerto Mosquito, the first detectable traces of ${ }^{137} \mathrm{Cs}$ were found at the $16-\mathrm{cm}$ depth, which was assigned as year 1954. Dividing $16 \mathrm{~cm}$ by 62 years (difference between 2016 and 1954) results in a sediment deposition rate of approximately $0.26 \mathrm{~cm} / \mathrm{yr}$. The ${ }^{210} \mathrm{~Pb}$ method provided a similar sediment deposition rate $(0.27 \mathrm{~cm} / \mathrm{yr})$ (fig. 17). The results for both lagoons are similar to other coastal lagoons in Puerto Rico; Laguna Grande has a sediment accretion rate of $0.44 \mathrm{~cm} / \mathrm{yr}$ (Soler-López and Santos 2010) and Laguna La Torrecilla has a rate of $0.37 \mathrm{~cm} / \mathrm{yr}$ (Webb and Gómez-Gómez, 1997).

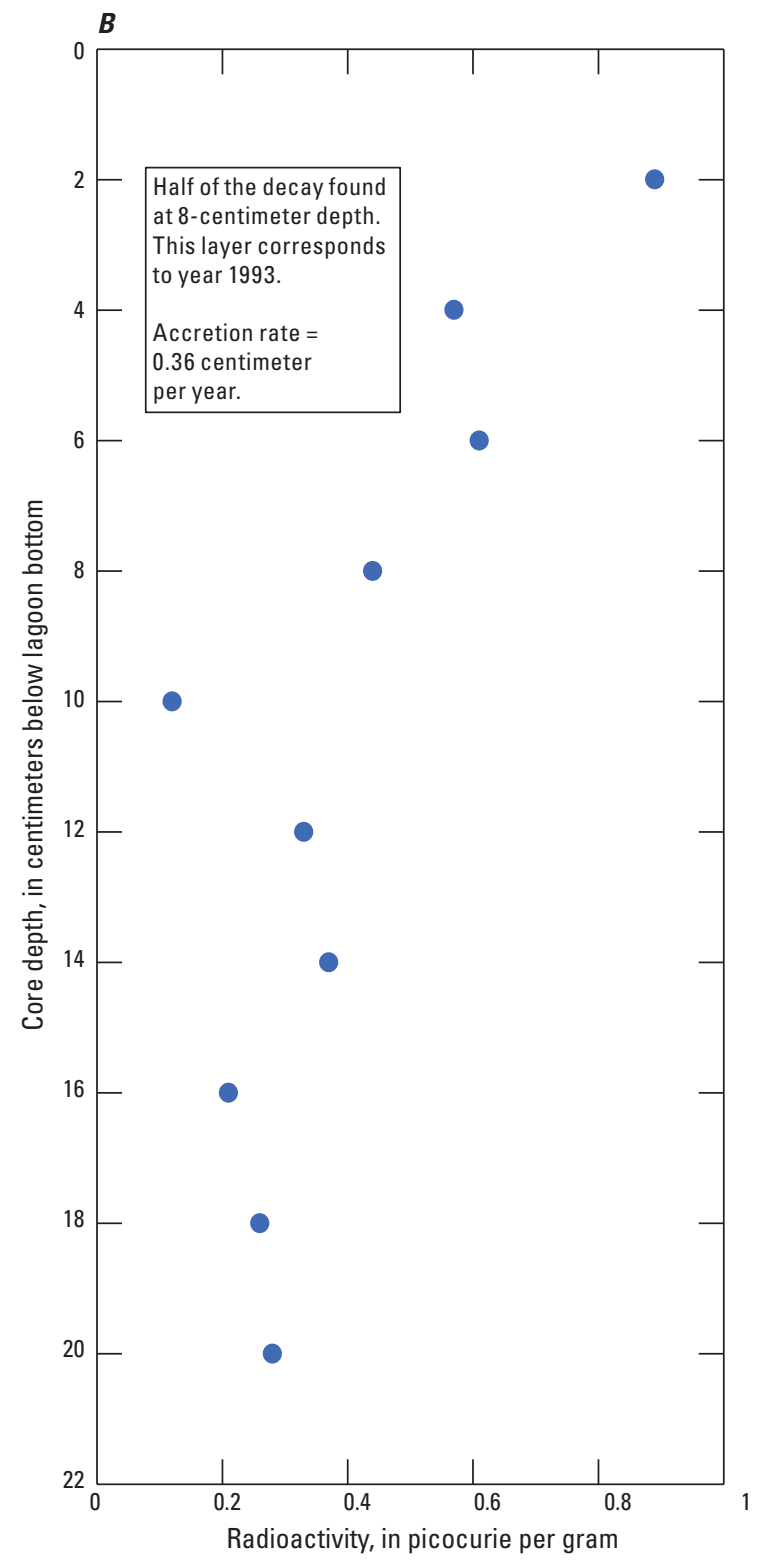

\section{EXPLANATION}

$\triangle$ Cesium-137 isotope sample

Figure 16. Relation of $A$, cesium-137 and $B$, lead-210 with sediment core depth in CB No. 2, Caño Boquerón, Cabo Rojo, Puerto Rico, December 2015. 

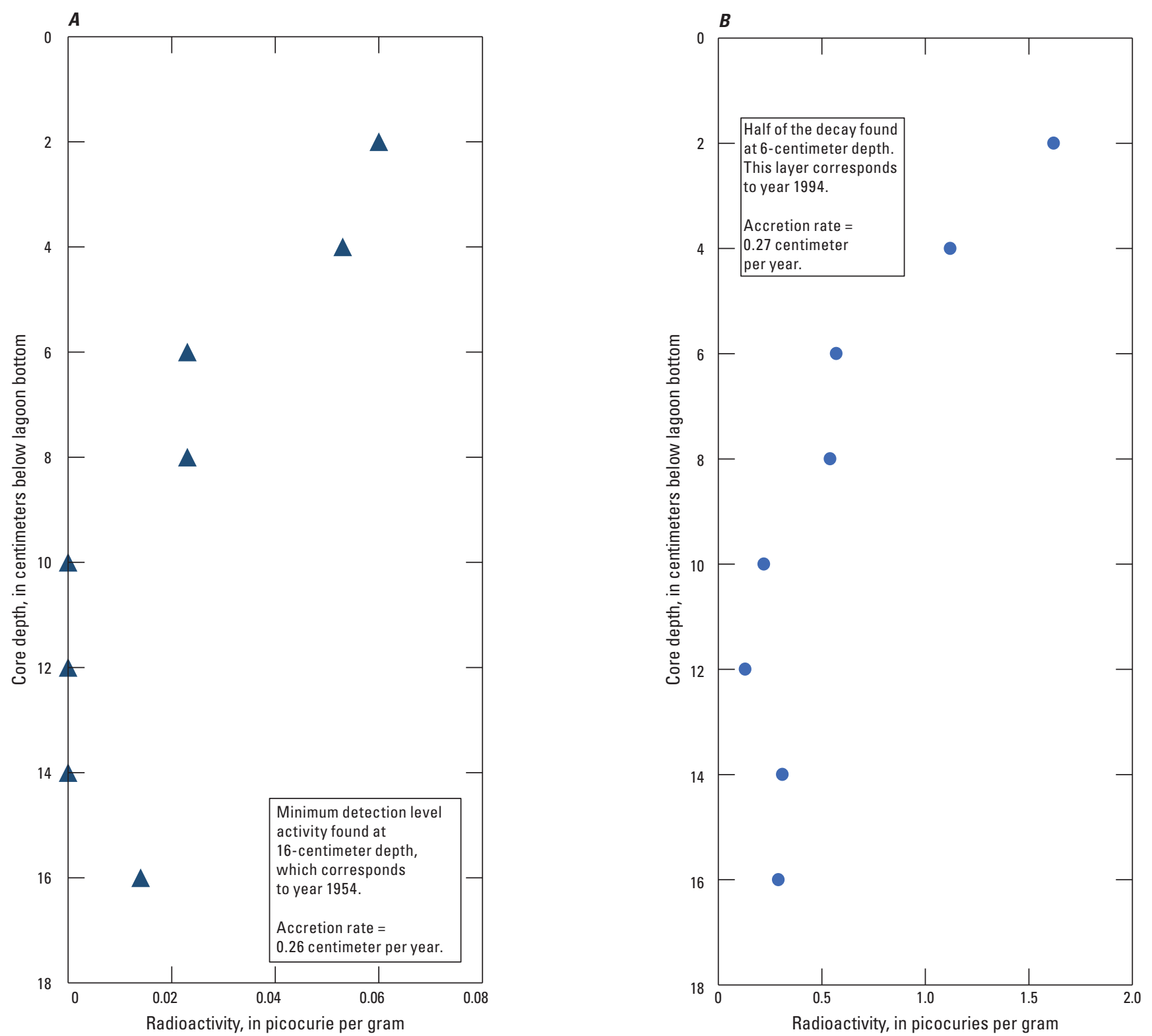

\section{EXPLANATION}
$\triangle$ Cesium-137 isotope sample
- Lead-210 isotope sample

Figure 17. Relation of $A$, cesium-137 and $B$, lead-210 with sediment core depth in PM No. 7, Puerto Mosquito, Isla de Vieques, Puerto Rico, January 2016. 


\section{Summary and Conclusions}

Continuous monitoring of coastal lagoons in Puerto Rico is needed because urban development and human disturbance are steadily increasing. A limnological study was conducted by the U.S. Geological Survey in cooperation with the Puerto Rico Environmental Quality Board (PREQB) to characterize the hydrologic and water-quality conditions at two previously unmonitored coastal lagoons (Caño Boquerón, Cabo Rojo, and Puerto Mosquito, Isla de Vieques, Puerto Rico). Caño Boquerón is located in southwestern Puerto Rico and is part of the municipality of Cabo Rojo; there are several potential sources of nutrients and other contaminants in proximity to Caño Boquerón. Puerto Mosquito is located on Isla de Vieques, a nearby island southeast of the Puerto Rico mainland in a pristine area undisturbed by development. The study included a bathymetric survey, rainfall-runoff analysis, monthly water sampling for determination of nutrients, analysis of physicochemical properties, and bacterial indicators. In addition, primary productivity by phytoplankton was evaluated along with the primary productivity in the benthos. Sedimentation rates in the lagoons were estimated using radioisotopes.

The bathymetric survey conducted in August 2015 for the Caño Boquerón lagoon indicated a mean depth of 1.5 meters and a storage volume of about 967,000 cubic meters $\left(\mathrm{m}^{3}\right)$. The mean depth of Puerto Mosquito was 1.8 meters, and the storage volume was $1,182,200 \mathrm{~m}^{3}$. Physicochemical properties assessed at Caño Boquerón indicated values generally in compliance with PREQB standards; turbidity and dissolved oxygen (DO) concentration occasionally were not within the established standards. Temperature ranged between 26.3 and 30.3 degrees Celsius $\left({ }^{\circ} \mathrm{C}\right)$, and DO concentration averaged about 4.9 milligrams per liter $(\mathrm{mg} / \mathrm{L})$ at the surface. The $\mathrm{pH}$ varied from 7.3 to 8.1, which is within PREQB standards. Specific conductance averaged 53,800 microsiemens per centimeter at 25 degrees Celsius $\left(\mu \mathrm{S} / \mathrm{cm}\right.$ at $\left.25{ }^{\circ} \mathrm{C}\right)$ and seasonal variability was observed with lower values occurring between October 2015 and January 2016. Nutrient analysis indicated that the total nitrogen and phosphorous concentrations for Caño Boquerón averaged about 0.24 and $0.029 \mathrm{mg} / \mathrm{L}$, respectively. Nutrient concentrations were below the PREQB established limits of 5 and $1 \mathrm{mg} / \mathrm{L}$ for total nitrogen and phosphorous, respectively. Water temperature at Puerto Mosquito ranged from 26.1 to $30.9^{\circ} \mathrm{C}$ at the surface. The average DO

concentration at the surface in Puerto Mosquito $(5.4 \mathrm{mg} / \mathrm{L})$ was higher than in Caño Boquerón $(4.9 \mathrm{mg} / \mathrm{L})$. The $\mathrm{pH}$ and specific conductance averaged about 7.9 and $54,400 \mu \mathrm{S} / \mathrm{cm}$ at $25^{\circ} \mathrm{C}$, respectively, for Puerto Mosquito, and 7.9 and $53,700 \mu \mathrm{S} / \mathrm{cm}$ at $25^{\circ} \mathrm{C}$, respectively, for Caño Boquerón.

The euphotic zone, which is defined as the water depth allowing sunlight penetration sufficient for photosynthetic processes, was determined by calculating water transparency using the Secchi disk method. Water transparency averaged 1.0 and 1.87 meters for Caño Boquerón and Puerto Mosquito, respectively. The productive volume associated with measured water transparency was calculated to be about $535,200 \mathrm{~m}^{3}$ at Caño Boquerón and 911,900 $\mathrm{m}^{3}$ at Puerto Mosquito.

Biological characteristics at both study sites were evaluated through primary productivity calculations and monthly water sampling for bacteriological and nutrients analyses. The light and dark bottles in-situ incubation and two diel studies were conducted to determine the primary productivity attributable to phytoplankton and to the entire community. In Caño Boquerón, net primary productivity by phytoplankton averaged about 0.74 gram of oxygen per cubic meter per day $\left(\mathrm{gO}_{2} / \mathrm{m}^{3}-\mathrm{d}\right)$ and average plankton respiration was $2.64 \mathrm{gO}_{2} / \mathrm{m}^{3}-\mathrm{d}$. Community net primary productivity averaged about $1.44 \mathrm{gO}_{2} / \mathrm{m}^{3}-\mathrm{d}$ and the average respiration rate was determined to be $8.10 \mathrm{gO}_{2} / \mathrm{m}^{3}$-d. In Puerto Mosquito, average phytoplankton net primary productivity was $0.39 \mathrm{gO}_{2} / \mathrm{m}^{3}$-d, and the plankton respiration rate averaged $1.68 \mathrm{gO}_{2} / \mathrm{m}^{3}$-d. Diel studies conducted at Puerto Mosquito determined an average community net primary productivity equal to $2.43 \mathrm{gO} / \mathrm{m}^{3}$-day, and respiration rates averaged $6.72 \mathrm{gO}_{2} / \mathrm{m}^{3}$-day. Comparison of diel study results indicated that the community net primary productivity in Puerto Mosquito is greater than in Caño Boquerón, with 16 percent provided from phytoplankton organisms at Puerto Mosquito; Caño Boquerón had 50 percent of the community primary productivity ascribed to the phytoplankton community.

Other productivity indicators such as phytoplankton biomass and chlorophyll $a$ were determined monthly from July 2015 to July 2016. In Caño Boquerón, phytoplankton biomass averaged about $11.12 \mathrm{mg} / \mathrm{L}$ and ranged from 7.4 to $21.50 \mathrm{mg} / \mathrm{L}$. The gross productivity to biomass ratio (P/B) for Caño Boquerón is 111, which is also a measure of the turnover of organisms per year. The average chlorophyll $a$ concentrations at stations CB No. 1 and CB No. 2 were 4.1 and $7.4 \mathrm{mg} / \mathrm{L}$, respectively. Phytoplankton biomass and chlorophyll $a$ concentrations measured at Puerto Mosquito averaged about $11.8 \mathrm{mg} / \mathrm{L}$ and $2.6 \mathrm{mg} / \mathrm{L}$, respectively. The turnover rate at Puerto Mosquito is 64 times per year.

Bacteriological analyses conducted at Caño Boquerón indicated that fecal coliform and enterococci concentrations did not exceed PREQB standards during the study. The maximum fecal coliform concentration (22 colonies per 100 milliliters) occurred at CB No. 1, whereas the maximum concentration of enterococci bacteria was 9 colonies per 100 milliliters. Maximum concentrations of fecal coliform and enterococci bacteria at Puerto Mosquito were 3 and 5 colonies per 100 milliliters of water, respectively.

Daily seawater exchange for the coastal lagoons was determined by using water-level fluctuations and total lagoon water volumes were estimated by bathymetric surveys. The daily seawater exchange referenced to mean sea level for Caño Boquerón and Puerto Mosquito was 13 and 5 percent of their water volumes, respectively.

Sediment deposition rates at both lagoons were determined using analyses of cesium-137 $\left({ }^{137} \mathrm{Cs}\right)$ and lead-210 $\left({ }^{210} \mathrm{~Pb}\right)$ radioisotopes in sediment cores. The average sediment deposition rates were about 0.32 and 0.36 centimeter per year 
for Caño Boquerón, based on ${ }^{137} \mathrm{Cs}$ and ${ }^{210} \mathrm{~Pb}$ radioisotopes, respectively. Results were similar for Puerto Mosquito, with sediment accretion rates of about 0.26 centimeter per year for ${ }^{137} \mathrm{Cs}$ and 0.27 centimeter per year for ${ }^{210} \mathrm{~Pb}$.

Both Caño Boquerón and Puerto Mosquito have substantial ecological value because coastal lagoons serve as nurseries for many aquatic organisms, as pollution controls for reefs, and as protective barriers against runoff and sediments for near coastal waters. High instability exists in coastal lagoons and several stress indicators are monitored by Federal and State agencies to help protect and preserve the aquatic life. Monthly water sampling at Caño Boquerón and Puerto Mosquito indicated that both lagoons function as mesotrophic inland waters and neither are degraded by excess nutrients. Continued monitoring can provide useful information to help identify potential disturbances or changes in water-quality conditions.

\section{References Cited}

Abigail, Anthony, Atwood, Joshua, August, Peter, Byron, Carrie, Cobb, Stanley, Foster, Cheryl, Fry, Crystal, Gold, Arthur, Hagos, Kifle, Heffner, Leanna, Kellog, D.O., Lellis-Dibble, Kimberly, Opaluch, J. J., Oviatt, Candace, Pfeiffer-Herbert, Anna, Rohr, Nicole, Smith, Leslie, Smythe, Tiffany, Swift, Judith, and Vinhateiro, Nathan, 2009, Coastal lagoons and climate changeEcological and social ramifications in U.S. Atlantic and Gulf Coast ecosystems: Ecology and Science, v. 14, no. 1, 8 p., accessed on September 28, 2016, at http://www.ecologyandsociety.org/vol14/iss1/art8/.

American Public Health Association, American Water Works Association, and Water Pollution Control Federation, 1995, Standard methods for the examination of water and wastewater (19th ed.): Washington, D.C., American Public Health Association, Inc., p. 10-25.

Billington, Neil, 1991, A comparison of three methods of measuring phytoplankton biomass on a daily and seasonal basis: Hydrobiologia, v. 226, no. 1, p. 1-15, accessed August 2016 at http://link.springer.com/article/10.1007/ BF00007775.

Boyer, J.N., Keible, C.R., Ortner, P.B., and Rudnick, D.T., 2008, Phytoplankton bloom status - Chlorophyll $a$ biomass as an indicator of water quality condition in the southern estuaries of Florida, USA: Ecological Indicators, v. 9, no. 6, p. 56-67, accessed September 28, 2016, at http://dx.doi.org/10.1016/j.ecolind.2008.11.013.

Briggs, R.B., and Akers, J.P., 1965, Hydrogeologic map of Puerto Rico and adjacent islands: U.S. Geological Survey Hydrologic Investigations Atlas HA-197. [Also available at https://pubs.er.usgs.gov/publication/ha197.]
Britton, L.J., and Greeson, P.W., eds., 1988, Methods for collection and analyses of aquatic biological and microbiological samples: U.S. Geological Survey Techniques of Water-Resources Investigations, book 5 , chap. A4, 685 p.

Caffrey, J.M., Murrell, M.C., Amacker, K.S., Harper, J.M., Phipps, Scott, and Woodrey, M.S., 2014, Seasonal and inter-annual patterns in primary production, respiration, and net ecosystem metabolism in three estuaries in the northeast Gulf of Mexico: Estuaries and Coasts, v. 37, no.1, p. 226, accessed September 28, 2016, at http://link.springer.com/ article/10.1007/s12237-013-9701-5.

Chrysoula, Christina, Giordani, Gianmarco, and Papastergiadou, Eva, 2014, Assessment of ecological quality of coastal lagoon with a combination of phytobenthic and water quality indices: Marine Pollution Bulletin, v. 86, nos. 1-2, p. 411-423. [Also available at http://www.sciencedirect.com/science/article/pii/ S0025326X14004184.]

Cornell, L.P., and Klarer, D.M., 2008, Patterns of dissolved oxygen, productivity and respiration in Old Woman Creek Estuary, Erie County, Ohio during low and high water conditions: The Ohio Journal of Science, v. 108, no. 3, p. 31-43.

Department of Environmental Conservation, 2015, Fact sheet-Turbidity in surface waters: Department of Environmental Conservation, State of Alaska, accessed May 22, 2017, at https://dec.alaska.gov/water/ wqsar/trireview/pdfs/Tri_Review_Turbidity_Fact_ Sheet_01-08-15.pdf.

Dodds, Walter, and Whiles, Matt, 2010, Freshwater ecology, concepts \& environmental applications of limnology, chap. 12 of Aquatic chemistry and factors controlling nutrient cycling: Elsevier, p. 302-305.

Dorsey, J.J., Carmona-Galindo, V.D., Leary, Christopher, Huh, Julie, and Valdez, Jennifer, 2013, An assessment of fecal indicator and other bacteria from an urbanized coastal lagoon in the city of Los Angeles, California, USA: Environmental Monitoring and Assessment, v. 185, no. 3, accessed October 5, 2016, at http://link.springer.com/article/ 10.1007\%2Fs10661-012-2737-3.

Eisma, Doeke, 1995, Present and future sea level-The effects of predicted global changes, chap. 3 of Climate changeImpact on coastal habitation: Lewis Publishers, p. 43.

Garen, D.C., and Moore, D.S., 2005, Curve number hydrology in water quality modeling - Uses, abuses, and future directions: Journal of the American Water Resources Association, v. 41, no. 2, accessed on November 17, 2016, at https://onlinelibrary.wiley.com/doi/ epdf/10.1111/j.1752-1688.2005.tb03742.x. 
Giusti, E.V., and López, M.A., 1967, Climate and streamflow of Puerto Rico: Caribbean Journal of Science, v. 7, no. 3-4, 7 p.

Gómez-Fragoso, J.M., and Santiago-Sáez, J.A., 2018, Data for the hydrologic and water-quality characterization of Puerto Mosquito, Isla de Vieques and Caño Boquerón, Cabo Rojo, Puerto Rico, July 2015-July 2016: U.S. Geological Survey data release, http://dx.doi.org/10.5066/F7WH2P6K.

Gonenc, I.E., and Wolflin, J.P., 2005, Biochemical cycle, chap. 4 of Coastal lagoons: Ecosystem processes and modeling for sustainable use and development (2005 ed.): Boca Raton, Fla., CRC Press, p. 81-85.

Herrera-Silveira, J.A., 1996, Salinity and nutrients in a tropical coastal lagoon with groundwater discharges to the Gulf of Mexico: Hydrobiología, v. 321, no. 2, p. 165-176. [Also available at http://link.springer.com/article/10.1007/ BF00023172.]

Horne, R.A., 1969, Marine chemistry: New York, John Wiley $\&$ Sons, Inc., 568 p.

Jamila, H., Mouldi, B., Moncef, G., 2016, Assessment of the water quality of Bizerte lagoon of Tunisia by use of statistical analyses: Hydrology Current Research, v. 7, 237 p. [Also available at http://dx.doi.org/10.4172/21577587.1000237.]

Karl, H.A., Chin, J.L., Ueber, Edward, Stauffer, P.H., and Hendley J.W., II, 2000, Beyond the Golden StateOceanography, geology, biology, and environmental issues in the Gulf of the Farallones: U.S. Geological Survey Circular 1198. [Also available at http://pubs.usgs.gov/circ/ c1198/C-1198.pdf.]

Menéndez, Margarita, Martítez, Marc, and Comín, F.A., 2001, A comparative study of the effect of $\mathrm{pH}$ and inorganic carbon resources on the photosynthesis of three floating macroalgae species of a Mediterranean coastal lagoon: Journal of Experimental Marine Biology, v. 256, no. 1, p. 123-136. [Also available at http://www.sciencedirect.com/ science/article/pii/S0022098100003130.]

Minnesota Pollution Control Agency, 2009, Low dissolved oxygen in water: Causes, impact on aquatic life-An overview: Water Quality/Impaired Waters, v. 3, no. 24. [Also available at https:/www.pca.state.mn.us/sites/default/ files/wq-iw3-24.pdf.]

Mohapatra Suchismita, and Patra, A.K., 2012, Studies on primary productivity of bay of Bengal at Puri sea-shore on Orissa: International Journal of Scientific and Research Publications, v. 2, no. 2. [Also available at http://www.ijsrp.org/research-paper-1012/ijsrp-p1074.pdf.]

Mumby, P.J., and Hastings, Alan, 2008, The impact of ecosystem connectivity on coral reef resilience: Journal of Applied Ecology, v. 45, no. 3. [Also available at http://onlinelibrary.wiley.com/doi/10.1111/j.13652664.2008.01459.x/pdf.]
National Aeronautics and Space Administration (NASA) Earth Observations, 2017, Sea surface salinity 2011-2015: Imagery by Kevin Ward, NASA Earth Observatory, based on data provided by the NASA Jet Propulsion Laboratory Physical Oceanography Distributed Active Archive Center (PO.DAAC), accessed January 5, 2017, at http://neo.sci.gsfc.nasa.gov/view. php?datasetId=AQUARIUS_SSS_M.

National Oceanic and Atmospheric Administration (NOAA), 2010, Mean annual rainfall 1981-2010 for Puerto Rico and U.S. Virgin Islands: National Oceanic and Atmospheric Administration website accessed June 2016 at http://www.srh.noaa.gov/sju/?n=mean_annual_ precipitation 2 .

O'Boyle, Shane, McDermott, Georgina, and Wilkes, Robert, 2009, Dissolved oxygen levels in estuarine and coastal waters around Iceland: Elsevier, Marine Pollution Bulletin, v. 58. [Also available at http://www.sciencedirect.com/ science/article/pii/S0025326X09002781.]

Odum, H.T., 1956, Primary production in flowing waters: Limnology and Oceanography, v. 1, no. 2, p. 102-117.

Puerto Rico Environmental Quality Board, 2014a, Assessment methodology for 305(b)/303(d) Integrated Report 2014 Cycle. [Also available at http:// www2.pr.gov/agencias/jca/Documents/Areas $\% 20$ Program $\%$ C3\%A1ticas/Evaluaci $\%$ C3\%B3n $\% 20$ y\%20Planificaci\%C3\%B3n\%20Estrat\%C3\%A9gica/ Divisi\%C3\%B3n\%20de\%20Planes\%20y\%20 Proyectos\%20Especiales/Draft\%202014\%20List $\% 20$ of $\% 20$ Impaired $\% 20$ Waters $\% 20$ and $\% 20$ Assessment $\% 20$ Methodology/Assessment $\% 20$ Methodology $\% 20$ for $\% 20$ 305b\%20303d\%20Integrated\%20Report \%20-\%20 Cycle\%202014\%20.pdf.]

Puerto Rico Environmental Quality Board, 2014b, Junta de Calidad Ambiental de Puerto Rico, Reglamento de Estándares de Calidad de Agua de Puerto Rico. [Also available at http://www.jca.pr.gov/.]

Puerto Rico Environmental Quality Board, 2016, Puerto Rico water quality standards regulation. [Also available at https://www.epa.gov/sites/production/files/2014-12/ documents/prwqs.pdf.]

Quiñones-Márques, Ferdinand, and Fusté, L.A., 1977, Limnology of Laguna Tortuguero, Puerto Rico: U.S. Geological Survey Water Resources Investigation 77-122, accessed on July 20, 2016, at http://pubs.usgs.gov/ wri/1977/0122/report.pdf.

Ritchie, J.C., and McHenry, J.R., 1990, Application of radioactive fallout cesium-137 for measuring soil erosion and sediment accumulation rates and patterns - A Review: Journal of Environmental Quality, v. 19, p. 215-233. 
Scheffer, Marten, 2004, The abiotic environment, chapter 2 in Ecology of shallow lakes: Springer Science \& Business Media, p. 20-75, accessed on September 28, 2016, at https://books.google.com/books?id=AVeUo9XHmCMC\&pg $=\mathrm{PA} 20 \&$ source $=\mathrm{gbs} \_$toc_r $\& \mathrm{cad}=3 \# \mathrm{v}=$ onepage $\& \mathrm{q} \& \mathrm{f}=\mathrm{false}$.

Selvam, V., Azariah, Jayapaul, and Azariah, Hilda, 1992, Diurnal variation in physical-chemical properties and primary production in the interconnected marine, mangrove, and freshwater biotopes of Kakinada coast, Andhra Pradesh, India: Hydrobiologia, v. 247, no. 1, p. 181-186. [Also available at http://link.springer.com/article/10.1007/BF00008217.]

Soler-Figueroa, B.M., 2014, Bioluminescence levels and dinoflagellates abundances at the bioluminescent bay Puerto Mosquito, Vieques, PR: Department of Marine Science, University of Puerto Rico, accessed on November 9, 2016, at http://drna.pr.gov/historico/bioluminiscencia/bahiamosquito-en-vieques/PM\%20final\%20report_11\%20 july\%202014_Final.pdf.

Soler-López, L.R., Gómez-Gómez, Fernando, and Rodríguez-Martínez, Jesús, 2005, Hydrologic, water-quality, and biological assessment of Laguna de Las Salinas, Ponce, Puerto Rico, January 2003September 2004: U.S. Geological Survey Scientific Investigations Report 2005-5154, 50 p. [Also available at http://pubs.usgs.gov/sir/2005/5154/.]

Soler-López, L.R., and Santos, C.R., 2010, Selected hydrologic, water-quality, biological, and sedimentation characteristics of Laguna Grande, Fajardo, Puerto Rico, March 2007-February 2009: U.S. Geological Survey Scientific Investigations Report 2010-5071, 51 p.

Thomaz, S.M., Enrich-Prast, A., Goncalves, J.F., Jr., Dos Santos, A.M., and Esteves, F.A., 2001, Metabolism and gaseous exchanges in two coastal lagoons from the Río de Janeiro with distinct limnological characteristics: Brazilian Archives of Biology and Technology, v. 44, no. 4, p. 433-438.
Thompson, R.F., 2014, Nearshore bathymetric mapping of a 7-mile reach of Lake Sharpe shoreline near Lower Brule, South Dakota, 2013: U.S. Geological Survey Scientific Investigations Map 3307, 2 sheets, accessed September 28, 2016, at http://dx.doi.org/10.3133/sim3307.

U.S. Geological Survey, variously dated, National field manual for the collection of water-quality data: U.S. Geological Survey Techniques of Water-Resources Investigations, book 9, chaps. A1-A10, available online at http://pubs.water.usgs.gov/twri9A.

U.S. Geological Survey, 2017, National Water Information System - Web interface, accessed January 18, 2017, at http://dx.doi.org/10.5066/F7P55KJN.

Volckmann, R.P., 1984, Geologic map of the Puerto Real Quadrangle, southwest Puerto Rico: U.S. Geological Survey Miscellaneous Investigations Series Map I-1559, scale 1: 20,000. [Also available at: https://pubs.er.usgs.gov/ publication/i1559.]

Wagner, R.J., Boulger, R.W., Oblinger, C.J., and Smith, B.A., 2006, Guidelines and standard procedures for continuous water-quality monitors: Station operation, record computation, and data reporting: U.S. Geological Survey Techniques and Methods book 1, chap. D3. [Also available at: https://pubs.usgs.gov/tm/2006/tm1D3/pdf/TM1D3.pdf.]

Webb, R.M.T., and Gómez-Gómez, Fernando, 1997, Synoptic survey of water quality and bottom sediments, San Juan Bay estuary system, Puerto Rico, December 1994-July 1995: U.S. Geological Survey Water-Resources Investigations Report 97-4144, 69 p.

Wetzel, R.G., 2001, Light in inland waters, chap. 5 of Limnology-Lake and river ecosystems (3d ed.): Elsevier, p. $49-69$. 
Publishing support provided by

Lafayette Publishing Service Center

For more information about this publication, contact Director, Caribbean-Florida Water Science Center U.S. Geological Survey

4446 Pet Lane, Suite 108

Lutz, FL 33559

(813) 498-5000

For additional information visit https://www2.usgs.gov/water/caribbeanflorida/index.html 


\section{$\frac{\mathbb{2}}{\mathrm{C}}$}

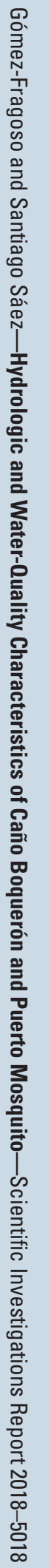

